\title{
Paradise Lost nor Regained. Social Composition of Theatre Audiences in the Long Nineteenth Century
}

As we said in the introduction of Longue Durée phenomenons in theatre, we will first turn to the question of the social composition of theatre audiences from the late eighteenth century to the Great War as they were made in theatre historiography from the late $19^{\text {th }}$ century till well into the twentieth century (and even to the present day). Once more, we start from the Rotterdam theatre archives, but the topics are not alien to international assumptions on audience composition. Once more we regard the assumptions about audience composition in traditional theatre historiography as a hypothesis to be tested. The order of the argument is as follows: Section 1 discusses the traditional theatre-historical view of audience composition in the long $19^{\text {th }}$ century, and specifies its often implicit assumptions and hypotheses. It also presents the data we used to test the given knowledge of theatre historiography. Section 2 presents the results of the analyses of the subscription lists. Section 3 concludes that audience composition shows aspects of longue durée. ${ }^{1}$

\section{Introducing the Case}

This section overviews the traditional notions of audience composition in the 'long $19^{\text {th }}$ century.' It specifies the markers involved and the hypotheses assumed, and discusses the data with which the traditional view will be tested.

\section{The Traditional View of Audience Composition in the $19^{\text {th }}$ Century}

Traditional theatre history assumes that theatre audiences were 'elite' in the late $18^{\text {th }}$ century, but that, due to melodrama, a product of the French Revolution, the social background of the audience declined. It was held that in the first half of the $19^{\text {th }}$ century, the lower middle class and even the working class took over the theatre, even on the best ranks. The elite fled to opera. It could be persuaded to return to drama only in the late $19^{\text {th }}$ century. About 1870 a movement set in for the elevation of the theatre. ${ }^{2} 1869-1870$ were the founding-years of the

1) Fernand Braudel, La Méditerranée et le monde méditerranéen à l'époque de Philippe II (Paris, 2d ed., 1966); Michel Vovelle, "Histoire des Mentalités, histoire des résistances, ou les prisons de longue durée," in: Le monde Alpin et rhodanien (1980). We consulted the Dutch translation in: Michel Vovelle, Mentaliteitsgeschiedenis (Nijmegen, 1985), pp. 142-169.

2) See for the traditional view particularly B. Hunningher, Een eeuw Nederlands toneel (Amsterdam, 1949) [A Century of Dutch Theatre], pp. 12-13; the same, Het dramatisch werk van Schimmel in verband met het 
Dutch Stage League, which, under the leadership of the banker-poet Schimmel, aimed at reconquering the stage for the upper bourgeoisie. De Leeuwe noticed that around 1870 the literate and rich bourgeoisie organised itself to reconquer the theatre for their own class, a process that showed its success in the 1890s. ${ }^{3}$ The fact that Queen Sophie visited The Danicheffs in 1876 was the ultimate proof that the balance had changed in favour of the 'civilized classes.' This is a narrative of Paradise Lost and Regained, focussing on the city elites and the working classes. The leading Dutch theatre historians of the middle twentieth century, particularly Hunningher, Albach, De Leeuwe, and Koster Leeuwe, adhered to this view.

The dominant narrative of Dutch theatre historiography meshes with the European historiographical tradition. Davis and Emeljanow sketched the British traditional narrative, supported amongst others by the authority of Allardyce Nicoll and George Rowell, as "a progression towards the restoration of literary drama, improved standards of production, and greater social respectability, both on and off stage." ${ }^{4}$ Here, too, the repertoire of melodrama was related to the social composition of the audience, and here, too, the power of the gallery audience caused the decline of the drama (p. 97). They quote Nicoll:

The stage in the early part of the century was largely a "popular" affair, and for the most part bourgeois opinion regarded its delights with cringing disapproval. Typical audiences were composed mainly of lower-class citizens with a sprinkling of representatives from the gayer or more libertine section of the aristocracy. The staid middle class and the respectable, dignified nobility tended to look upon the stage as a thing not to be supported in an active manner. ${ }^{5}$

Rowell is quoted for his conviction that in the early $19^{\text {th }}$ century "butchers and barber had driven (...) fashionable clients from the pit to the boxes, or in many cases out of the playhouse altogether" (ibidem). Nicoll and Rowell also saw things improve in the later $19^{\text {th }}$ century, because of the good taste of some actor-managers (Macready, Phelps, the Bancrofts, Irving,

Amsterdamsche tooneelleven in de negentiende eeuw (Amsterdam, 1931) [The Dramatic Work of Schimmel, as related to Amsterdam Theatre Culture in the nineteenth Century], p. 3. Also B. Albach, Helden, draken en komedianten (Amsterdam, 1956), [Heroes, Blood and Thunder Plays, and Comedians], p. 141; H.H.J. de Leeuwe, "De geschiedenis van het Amsterdamse toneelleven in de negentiende eeuw (1795-1925)," in: A,E. d'Ailly, ed., Zeven eeuwen Amsterdam, 6 Vols. (Amsterdam, n.d. [1948]) [“The History of Amsterdam Theatre Life, 1795-1925," in: Seven Centuries Amsterdam], V, pp. 6 and 12, but see also the same, "Silepochen des holländisches Theaters im 19. Jahrhundert," in: Maske und Kothurn, 3:4 (1957), 340-62; and the same, "Antoine Jean le Gras, een Nederlands regisseur der negentiende eeuw in Rotterdam," in: Rotterdams Jaarboekje [“Antoine Jean le Gras, a Dutch director in Nineteenth Century Rotterdam”] (1975), 209-256, see p. 211. S. Koster, Comedie in Gelderland (Zutphen, 1997).

3) De Leeuwe, “Antoine Jean le Gras” (1975), 221.

4) Jim Davis and Victor Emeljanow, Reflecting the Audience. London Theatregoing, 1840-1880 (Iowa, 2001), pp. 97-98. The works in question are Allardyce Nicoll's A History of English Drama, 1660-1900, Vol. 4, Early Nineteenth-Century Drama 1800-1850 (Cambridge, ${ }^{2}$ 1970) and Vol. 5, Late Nineteenth-Century Drama 1850-1900 (Cambridge, 1946). George Rowell, The Victorian Theatre 1790-1914 (Cambridge, ${ }^{2} 1978$ ).

5) Davis and Emeljanow, Reflecting the Audience (2001), 98. 
Gilbert and Sullivan), which brought back a better-mannered audience. Queen Victoria interested herself in this process of refashioning manners in theatre audiences and elevation of the repertoire. ${ }^{6}$ What would have become of the theatre if there hadn't been queens?

Of France and Germany comparable stories are told. With respect to the latter (divided) country, the (probably apocryphal) instance of Goethe giving up his position as intendant in Weimar because of the staging of Pixérécourt's Le Chien de Montargis (in which a dog played the lead), has been given symbolic value. ${ }^{7}$

Somewhat surprisingly, this traditional narrative was recently rehearsed by the leading American theatre historian Bruce A. McConachie in Melodramatic Formations. ${ }^{8}$ We return to his 'post-positivist' project below (Chapter \#\#). In the Netherlands, we are not, of course, the first to criticise the traditional narrative. Hennie Ruitenbeek reconstructed the income and cost of living, and concluded that it was highly unlikely that even petty shopkeepers and artisans, let alone skilled or unskilled labourers, could regularly have attended performances in the Amsterdam City Theatre. ${ }^{9}$ However, her view, given in Kijkcijfers [Viewing Figures] (2002), that the City Theatre was not in decline, because the performances brought in quite some money, puts the cart before the horse. Critics and historians complained about the quality of the audience's composition, which cannot be deduced from rough estimations of the number of spectators. ${ }^{10}$ For the London theatre in the $19^{\text {th }}$ century Davis and Emeljanow likewise criticised the narrative of decline and resurrection of quality drama and audiences for the London stage. Using among other materials, playbills, newspapers, transport schedules, and the census reports, they rejected the idea that theatres were class-based. Yet, they still maintained the view of 'the more low melodrama the more lower-class theatre-goers.' Our concern with their view centres on the poor quantitative analysis. ${ }^{11}$ Since the authors assumed

6) Davis and Emeljanow, Reflecting the Audience (2001), 98.

7) More likely, he gave up when the duke of Weimar's mistress, the actress Caroline Jagermann was given control over the company. The Weimar theatre in its heydays staged three plays per week, of which one was a musical play, and another a Von Kotzebue of Iffland play. See Marvin Carlson, Goethe and the Weimar Theatre (Ithaca, 1978), John Prudhoe, The Theatre of Goethe and Schiller (Oxford, 1973).

${ }^{8}$ ) Bruce A. McConachie, Melodramatic Formations. American Theatre \& Society, 1820-1870 (Iowa City, 1992).

9) Hennie Ruitenbeek, "Byna te arm tot schouwburgtydverdryf': Sociale geleding en levensstandaard van het publiek in de Amsterdamse Stadsschouwburg in de eerste helft van de negentiende eeuw," in: EconomischSociaalhistorisch Jaarboek ['Almost too Poor for Theatre Amusements': Social layers and Standard of Life of the Audience of the Amsterdam City Theatre], 56 (1993), 94-149.

$\left.{ }^{10}\right)$ Hennie Ruitenbeek, Kijkcijfers [Ratings] (Amsterdam, 2002). For the Amsterdam theatre there are lists of receipts roughly from the early 1820 s till the early 1840 s. Only for the seasons 1835-36 and 1838-39, ticket sales accounts per rank are available.

$\left.{ }^{11}\right)$ Jim Davis \& Victor Emeljanow, Reflecting the Audience (2002). 
that theatres were predominantly patronized by people from the vicinity, they turned to the census reports to reconstruct the local population. The enumerations from the census reports in the many case studies, however, led to little insight, because they are not grouped and statistically analysed; hence, do not lead to a clear synchronic and diachronic picture of the development of the social structure of patrons, neither in the districts under consideration, nor in the synthesis. Still, a complex and detailed picture of play-going and audiences composition is the result, a result which throws doubt on the Nicoll-Rowell view.

\section{Assumptions and Hypotheses Implied in the Traditional Narrative}

Let us begin with specifying the often implicit assumptions of theatre historians with respect to the social characteristics of the audience during the long $19^{\text {th }}$ century. These provide clues of what might be expected and give shape to the analysis of the subscription lists. Occupation and wealth were deemed highly relevant. Hunningher conjectured that an 'elite' patronage in the late $18^{\text {th }}$ century changed from about $1805-1870$, at least for drama, to a patronage of the lower middle classes and the uneducated labourers. After 1870 the 'elite' took possession of the theatre once more. Albach, Koster, and De Leeuwe largely followed this view. It is, thus, to be expected that the dominant audience in the late $18^{\text {th }}$ century had occupations and wealth above the middle class job categories, which brings us to the aristocracy of regents, merchants, finance, and academic occupations. With regard to the social characteristics of subscribers in the 'melodrama years' (ca. 1805-1870) we should expect a considerable drop in occupation and wealth categories for Dutch-spoken drama performances (artisans, small shopkeepers, working class persons like dock-hands, and so on). Occupation and wealth categories were supposed to rise to their former glory after 1870. Moreover, we should expect in the first half of the $19^{\text {th }}$ century a huge social division between opera- and drama-patrons as well. The traditional historiography also implies that subscribers for season tickets and coupons in the period ca. 1805-1870 must have been significantly poorer than those before and after, at least for drama.

Job category and wealth, of course, are not the only variables to establish an elite or non-elite audience. Most likely, social and political functions will relate to occupation and wealth, since voting right (relevant since 1795) depended on wealth (census). Thus, it is to be expected that subscribers for drama in the period 1805-1870 held considerably less functions than subscribers before and after these dates, whereas all drama subscription cohorts should differ sharply from opera cohorts. Moreover, in the years in which the elite was supposed to have ruled the theatre, we must also expect a good deal of organized political activity since only voters partook in election clubs. ${ }^{12}$ Both Hunningher and De Leeuwe referred to

\footnotetext{
12) Election clubs were formed from 1848 onwards. It took till about 1870 before non-voters were allowed in election clubs in Rotterdam.
} 
differences in education (Hunningher: spoke of "completely uneducated labourers" for melodrama; De Leeuwe: speculated on "petty bourgeois with little comprehension"). ${ }^{13}$ Thus, we must also expect differences in informal education shown in memberships of cultural societies (sociability), and formal school education.

There are also relevant variables which the traditional narrative strangely neglects. The first of them is religion as a social-cultural variable. This variable is relevant in view of the wide-spread theatrical prejudice in the Christian tradition, especially Calvinism, the official religion in the Netherlands. We must expect religion to have influenced the composition of theatre audiences, the more orthodox denominations being under-represented. Also, the older literature does not consider age. Urban merchants and middle classes married often relatively quite late. ${ }^{14}$ Sons had to wait till they could succeed their fathers or carve a living independently. It might be that there is a demographic differentiation in the cohorts of season ticket and coupon holders. Perhaps, for instance, the younger generation, waiting for their fathers to retire, amused themselves in the theatre, or perhaps the opposite occurred, or both. McConachie for instance, envisioned 'waning patriarchs' at the melodramas in the 1820s and 1830s, which implies an elderly group of frustrated upper bourgeois. The New Rotterdam Courant (1844ff.), however, repeatedly noticed many 'children' in the theatre. ${ }^{15}$ Of course, attention must also be paid to the presence of women in the audience. McConachie (and many other theatre historians) stressed that few women attended drama performances in the late $18^{\text {th }}$ and early $19^{\text {th }}$ century. A final aspect, hardly mentioned in theatre history literature, but featuring in the sociology of culture is social mobility. This aspect is implied in the dominant narrative, since it assumes that elites were hereditary theatre-goers: the late $18^{\text {th }}$-century 'elite' drama patrons, cannot have been the same 'elite' persons, who flocked to opera in the 1840s. It must have been their (grand-)children. Assumed is also variance in social background: melodrama audiences supposedly were predominantly lower middle or working class persons, who conquered the theatre due to upward mobility in the Revolution era. We must then expect the same, or an even lower status for their (grand-)parents in the late ancien regime. That leaves us with the following markers: occupation, wealth, social and political functions, sociability, education, political allegiance, age, gender, religion, and a genealogical component that must give us insight in social mobility.

With respect to the larger typification of the audience as elite we must pay respect to the results of Pierre Bourdieu's empirical research into participation in culture as related to

\footnotetext{
$\left.{ }^{13}\right)$ Hunningher, Century of Dutch Stage (1949), 26-27; De Leeuwe, “Antoine Jean le Gras” (1975), 211.

${ }^{14}$ ) The Physiology of Rotterdam (The Hague, 1844), states that upper bourgeois sons married at about 30 years of age.

${ }^{15}$ ) This started from the first year: 'An Amateur of Theatre' wrote in a letter The Stage cum Annexis at Rotterdam (22-10-1844), that the pit audience consisted for a "not mean part" of children.
} 
(many) other social variables. ${ }^{16}$ Bourdieu constructed three types of taste (high brow, middle brow, low brow) and also two rival social formations, those who mint social prestige from cultural capital and those who mint it from economic capital. This is to say, a high educated, often state-employed, well-paid class distinguishes itself, by a predilection for avant-garde art forms, from a class of money-makers, not necessarily uneducated, whose taste tends generally to more traditional art forms. In terms of mentality, the carriers of cultural capital stress a cognitive, intellectual approach to 'art,' whereas for the carriers of economic capital 'art' is a form of recreation, which works on the emotions (including a basic pleasure as laughter). With that comes an aesthetic predilection for abstract art versus a liking of beautiful things well imitated.

\section{New Empirical Data for Audience Composition}

The Rotterdam Theatre Archives contain a number of lists of subscribers for season tickets and coupons (booklets with at the minimum five or six tickets). The lists are specified in appendix 1. For sake of space and clarity, we will utilize here the following aggregated cohorts:
1. Dutch-spoken Drama, 1773-92
57 persons
253 persons
115 persons
582 persons
7. Dutch-spoken Drama, 1890-95
1476 persons
9. Dutch-spoken Drama, 1902-12
124 persons
2. French Opera, 1789-92 120 persons
4. French Opera, 1917-44 276 persons
6. 'French Opera,' 1852-59 134 persons
8. German Opera, 1860-82 1150 persons
10. Maifestspiele, 1909-11 677 persons
12. Opera Italiana, 1933240 persons

These 'persons,' of course could have subscribed for e.g. their wives, children, or friends. In terms of the traditional narrative, these cohorts cover four periods: (a) The later years of the ancien régime, when the comédie larmoyante split, and the opéra comique pleased a presumably elite audience (cohorts 1-2). (b) The 'melodrama years,' first half of the $19^{\text {th }}$ century, during which the elite is believed to have been absent from drama performances, and a huge social cleft existed between drama and opera subscribers (cohorts 3-4). (c) A transition period, in the $1860 \mathrm{~s}$, when slowly the drama-repertoire changed to realism, and the Royal French Opera was replaced by the Rotterdam German Opera, introducing Wagner. We included here the first shareholders of the 1851-1887 Grand Theatre as representing the French Opera, 1852-1859. ${ }^{17}$ Especially German opera was considered to attract the elite, but

\footnotetext{
$\left.{ }^{16}\right)$ Pierre Bourdieu, transl. Richard Nice, Distinction. A Social Critique of the Judgement of Taste (London, 1989), originally published in 1979.

$\left.{ }^{17}\right)$ These shareholders never got free entrance, but had the right of pre-subscribing for seats. As the minutes make clear, most of them did so for the balcony, boxes, or the pit. We refer to this cohort as pseudo-French Opera, 1852-1859. The number of season ticket holders at the French Opera was considerably higher than the 134
} 
drama was still supposed to cater for a middle class audience (cohorts 5, 6, 8). (d) The period of the recovery of drama, when acting improved and the repertoire made the better sort of people is believed to have returned to the theatre (cohorts 7, 9, 10).

For opera after 1900, we have only data for part of the Maifestspiele and the much later subscribers for the Opera Italiana (1933). For drama after 1914, we have one subscription list for season tickets for the Rotterdam Stage Company (1959-1960). ${ }^{18}$ Originally during the Maifestspiele the Ring des Nibelungen was twice performed, but the last two festivals, in 1909 and 1911, had a mixed repertoire. The performances were given by German troupes. An assessment of the data is given in appendix 2. Except for the first two seasons of the Rotterdam German Opera, shareholders never got free entrance.

The social markers of the subscribers have been researched, leading to a database now containing over 14,500 person files. We sought data on name, sex, noble title, address, date and place of birth, date of marriage, date of death, the place from which they migrated or to which they departed, occupation, wealth, religion, social and political functions, sociability, theatre seasons, subscription for or against the Rotterdam fair, education, political allegiance. Also we collected data for wives (or in a minority of cases, of husbands), father, mother, grandfather and grandmother of the shareholder or subscriber, provided they were born in Rotterdam or the towns of which Rotterdam now stores the population registers. Appendix 2 gives information on the sources for the data.

Season tickets and coupons were not available for the cheep ranks. In all three consecutive Grand Theatres subscription for the upper tier was impossible. The number of tiers, however, increased every time the Grand Theatre was reconstructed. There were three tiers in the first Grand Theatre, Coolsingel, and five in the third (Aert van Nesstraat). Also, considerably less subscriptions were made for ranks lower than the first (stalls, boxes, balconies, and baignoires). Since the issue with traditional theatre historiography is particularly the question of the participation of the upper classes, the skewness in the data, due to the distribution over ranks and income is not a hindrance for the historical part of the analysis, but a major obstacle for sophisticated statistical tests: only non-parametric tests could can be applied to this database.

shareholders (more like 300 to 400).

$\left.{ }^{18}\right)$ The 240 subscribers for the 1933-34 season of the Opera Italiana (1898-1942), and the 120 subscribers for the 1959-60 season of the Rotterdam Stage Company (1947-1962), do not yield as many social markers as the $19^{\text {th }}$ cohorts, because the archive basis has dramatically deteriorated. The abolition of the local taxes in 1922 makes it impossible to gather data on wealth, while also information on functions, sociability, and political stand, yes, even on the subscribers themselves are less easy to find, by legal embargoes and negligence. We deal with the post-1914 cohorts in an appendix (appendix 3). 


\section{Analyses of the variables}

This section presents the analyses of the social variables of the subscribers. We will first address the question whether melodrama audiences in the first half of the $19^{\text {th }}$ century indeed were predominantly lower middle class or even working class persons and whether the elite indeed massively preferred opera above drama. Then the social characteristics of the subscribers over the whole period are surveyed, distinguishing between the social variables explicitly addressed in the traditional historiography and the social variables implicit in it, especially religion, age, and the issue of women in the subscribing audience. The analysis ends with specifying differentiations per rank, and the background of the subscribers. Appendix 3 gives the basic cross-tables of the variables over the period 1773-1912. We will refer to these cross-tables in the following analyses. Tables are thematically numbered after the order of the basic tables in appendix 3. So, all tables having to do with occupation and wealth are numbered $1 \mathrm{a}, 1 \mathrm{~b}$, etc., and all tables having to do with religion are numbered $3 \mathrm{a}$, $3 \mathrm{~b}$, etc.

\section{A New Audience at Melodrama?}

With respect to professional occupations, the traditional historiography assumed a (lower) middle class and working class audience. From table 1a (appendix 3) it is clear that most of the melodrama subscribers (cohort 1824-1830) fall in the category 'trade' (62 per cent), middle class occupations and professionals limp far behind (15 and 13 per cent respectively). This distribution refutes the assumption of the traditional view. With respect to wealth, the melodrama cohort indeed stands out, not only with respect to other drama cohorts, but also to the parallel opera cohort, the French Opera (1817-1844). A distribution which decreases by about 50 per cent per wealth class (though from the third class onwards) is only weakly repeated in the $18^{\text {th }}$-century drama cohort (1773-1792), but there we found data on rateable value for only 49 out of 157 subscribers, and those were at best twelve years after the subscription (register, 1803). Also, the fact that we deal with rateable values for the melodrama cohort makes complicates comparison with other drama, since these are based on different wealth data. To give more context to the figures, we also analysed the so-called taxable income based on real estate, that is, the sum rateable value of a person's realty. It turned out that 83 of 132 melodrama subscribers who were taxed for real estate, possessed realty over fl. 1000.- rateable value (63 per cent). Thus, while 32 persons in the melodrama cohort lived in a house with a rateable value over fl. 1000.-, fifty-one subscribers possessed realty larger than that sum (twenty-two persons, 17 per cent, held realty with a sum rateable value over fl. 3000.-, of whom six very rich peaked over fl. 5000.-). Though we would not sustain the assumptions of the traditional narrative on the basis of the rateable values (the 103 values between fl. 200.- and 600.- can only be regarded as a solid wealth position), the 
additional data on taxable income clearly falsify the assumptions with respect to the wealth of melodrama subscribers.

As explained in Appendix 2, the subscribers for season tickets in 1824-1830 formed an average of some 50 per cent of the pit audience per season. Against a downgrading of notsubscribing audiences in the pit during the melodrama years we may call attention to class sensitivity. It is unlikely that gentlemen of a Reepmaker, Van Rijckevorsel, and Van Vollenhoven stock would be prepared to rub shoulders with butchers' boys or hawkers in the pit. It is even doubtful whether these latter would have been the regular audience of the gallery, for a ticket there cost 60 cents. That was not the sort of money for many an artisan, let alone workmen in the docks or construction to spend on a play. Likely it was even too much for many a small retailer, independent artisan, clerk, or employee to spend regularly. ${ }^{19}$ Possibly part of these groups caused the high peaks in occupation rates in Fair-time of benefit performances, or the yearly New-year's performance of Vondel's Gijsbrecht van Aemstel. There is no reason to assume radical changes in the composition of this audience in the period ca. 1770-1860 which are not related with changes in the social structure according to occupation in itself (such as e.g. the increase of employees after 1815).

We expected, due to the census voting right, that power, expressed in political and social functions, would go along with wealth. Table 4a (appendix 3) confirms this. The number of functions, to be sure, is a gross list of the functions a person held throughout his career. We calculated the average number of functions per function-holding subscriber, and also the average number of functions in the cohort. This latter figure we defined as the functional weight of a cohort. With an average of three functions per function holder, and a functional weight of 1.2 the assumption that melodrama patrons had a low status is falsified. Function-holding in the melodrama cohort differed not much from that in the late ancien regime, where the traditional narrative assumed an educated elite, and it was larger than that in the drama cohorts around 1900.

Traditional theatre historiography stressed the low level of education of melodrama audiences. We considered education in the form of sociability and as formal school training. Table 5a (appendix 3) gives the distribution of memberships of societies. Here, too, it concerns a gross list of all collected memberships held in life. Again, the melodrama cohort does better than the late $18^{\text {th }}$ century cohort, but worse than the later drama cohorts (sociable subscribers had an average membership of 2.4 per person, and the sociable weight of the cohort is 1.0). Figures on sociability, however, depend more strongly on available archives

\footnotetext{
19) An analysis of poll-tax in the years 1860 of about 350 members of the literary society Amicable Literary Exercise, which society consisted half of white collar workers and half of shopkeepers and artisans, showed that more than half of them could spend some fl. 500.- to fl. 1,250.- per year (lowest tax scales), while a considerable number of them were below this threshold (GAR, VLO, membership lists and minutes). Herman Heijermans, journalist for the liberal New Rotterdam Journal regarded a weekly income of fl. 10.- per week (too) high for a working class labourer (Sunday Journal, 5-12-1868).
} 
than political and social functions, and the archival situation at the end of the $19^{\text {th }}$ century is considerably better than in the melodrama years or the late $18^{\text {th }}$ century. ${ }^{20}$

Data on formal education are very hard to find before the 1860s. The only data available concern higher education (university and the medical school) and the Latin school. ${ }^{21}$ Against the view of a completely uneducated audience or one with little comprehension argue the fourteen melodrama subscribers with higher education and the one grammar-school pupil. The drama cohort of the ancien regime counted only two university-trained subscribers. The assumption of a generally illiterate melodrama audience is, to our view, to be rejected.

Due to the political system and poor records, little is known about the political stand of the melodrama subscribers. We detected two conservative subscribers, one conservative liberal and three liberals. Melodrama subscribers at least counted twelve former democrat Patriots, but no former Orangist. ${ }^{22}$ The majority of the merchant elite families subscribing in the melodrama cohort had Patriot backgrounds, either of themselves, or through their fathers. We counted 26 Patriots and two Orangists in the father generation (150 fathers), and ten Patriots against three Orangists in the grandfather generation (65 grandfathers).

In comparison, the larger French Opera cohort (1817-1844), counted only six former Patriots and two Orangists. This cohort, of course, counts more persons, who were too young to participate in the party struggles of the $1780 \mathrm{~s}$. In the father generation indeed more data were found: 37 fathers had a Patriot background, against ten Orangists (178 fathers). In the grandfather generation these figures are 14 Patriots and 7 Orangists (99 grandfathers). Here, too, the tendency is towards democratic Patriotism, but Orangism manifested itself stronger at the Opera than with melodrama. Perhaps the managers of the drama company were right to stress that subscribing for drama was an act of patriotism in the sense of 'nationalism.'

This comparison has taken us to the second issue, to wit the supposed cleft between drama and opera-goers in the first half of the $19^{\text {th }}$ century. Table 1a (appendix 3 ) suggests just minor shifts in the distribution of occupations. The most remarkable, but still relatively small, is the difference between middle class drama subscribers and opera subscribers (10 per cent points less middle class at the opera), which equals the difference of academics in both forms of theatre (10 per cent points less academics at melodrama). Wealth, however, stated in rateable values, is far more equally spread in the French Opera cohort (1817-1844) than in the melodrama cohort. Of the opera-goers, 121 persons (77 per cent) owned realty yielding more

${ }^{20}$ ) We lack, for instance, membership lists of the Society for Public Welfare, Harmony, and the earliest membership lists of the Society for the Advancement of Music.

$\left.{ }^{21}\right)$ Higher education as defined in the tables include the university, the medical schools, the technical highschools, and the high-school for trade. All of these forms of education now have a university status.

22) This is curious in a way. Orangism after 1787 was, of course, dominated by the aristocrat regents, but the Orangist 'party' itself, its street fighters so to say, consisted for a large part of the classes, which the traditional theatre historians defined as melodrama audience. 
than fl. 1000.- rateable value, and of those 32 persons ( 21.5 per cent) owned realty yielding a rateable value over fl. 3000.-, twelve persons peaking over fl. 5000.-. This is better than the melodrama cohort, but it does not at all sustain the conjecture, that the city elite massively turned its back on melodrama and went to the opera. Of the melodrama subscribers 69 also subscribed for the French Opera (1817-1844), which is 27 per cent of the melodrama cohort, contributing 25 per cent of the Opera cohort. Some of the older melodrama subscribers still subscribed for the German Opera in the 1860s.

The better wealth position of the opera cohort mirrors itself in a larger participation in political and social functions (table 4a, appendix 3). The functional weight of the French Opera, 1817-1844 is 2.6, thus more than twice that of the melodrama cohort (average number of functions per function holder is 4.3). The political stand of the opera-subscribers was also somewhat better to trace than those for melodrama: we detected seventeen liberals, nine conservatives, and two conservative liberals, which is ten per cent of the subscribers. For melodrama the political stand could be traced for only two per cent of the subscribers. This difference is due to the different measures in which subscribers were active in the election clubs formed after 1848, and it must be kept in mind that the melodrama cohort was about 20 years removed from that effect of the revolution. Yet, also considering the relative fewer functions, it is reasonable to say that more opera-subscribers than melodrama subscribers became part of the post-1848 political elite.

As might be expected, sociability and formal education in the opera cohort scored better than in the melodrama cohort (tables $5 \mathrm{a}$ and $6 \mathrm{a}$, appendix 3): the sociability weight of the melodrama was 1.0 against 2.1 for the opera. Considerable more subscribers for opera partook in cultural and social societies (71 against 41 per cent). Yet, the melodrama subscribers were members of the same elite societies, both cultural and social, as those for the opera. Only four participated in typical middle class literary societies. ${ }^{23}$ The French opera-subscribers scored better on formal education, too, and counted 41 persons with higher education and two with grammar school. This is, of course, mainly due to the larger part of academics participating in the opera cohort.

All in all both tenacious assumptions of traditional theatre historiography cannot be maintained: in the first half of the $19^{\text {th }}$ century, melodrama did not just draw lower middle class and working class patrons. At least half of the pit audience consisted of solid citizens and the merchant elite. This merchant elite also visited the opera, thus, falsifying the conjecture that the elite massively left drama for opera.

${ }^{23}$ ) It concerns In Friendship Active. In the French Opera one subscriber was to become a member of Amicable Literary Exercise, which had less status than In Friendship Active. 
An Overview of the Explicit Social Variables of the Subscribers, 1773-1912

This section surveys for the whole period, 1773-1912, the variables which explicitly played a role in the traditional theatre historiography of audience composition: job category, wealth, functions, sociability, education, and political allegiance. We argue that not only the conjectures about melodrama patrons and the difference of patronage at the opera and drama are untenable, but that in fact the narrative of Paradise lost (in the French Revolution), and regained (after the Paris Commune), cannot be maintained neither.

Table 1a (appendix 3) presents the aggregated data on job categories and wealth classes. It appears that the distribution of wealth and job categories per cohort remains stable. 'Trade' dominates, and all other categories limp far behind. For $19^{\text {th }}$-century Dutch-spoken drama, 'middle class' occupations normally take the second place, followed by the 'professionals.' These take over the second place after 1900. This has likely to do with the trade organizations of office clerks, who often bargained for special prices. For opera, this picture is less rigid. The overall skewness tending to high income is noticeable: trade is not only by far the largest job category, but also takes a lion's share in wealth in most of the cohorts. ${ }^{24}$ The difference between opera and drama remains visible but relative. ${ }^{25}$

The data for both the late $18^{\text {th }}$-century cohorts are a bit unsatisfactory, because for drama (1773-1792) the number of missing items is large (108 of 157). For this cohort the Marriage and Burial Tax (MTB) gives a better result, but is as a measure not very satisfying. The MTB was based on riches at the time of death. In the highest class one paid fl. 30.-; in the second class fl. 15.-; in the third fl. 6.-; in the fourth fl. 3.-. There was also a pro deo class for the poor. The highest class, however, was related to a fortune of fl. 12,000.- (it halved per tax class) and it turned out that for the theatre-goers this measure hardly differentiated wealth.

\begin{tabular}{lllll} 
& \multicolumn{4}{l}{ Drama $(\mathbf{N}=\mathbf{1 5 7})$} \\
tax sum $\rightarrow$ & $3 .-$ & $6 .-$ & $15,-$ & $30 .-$ \\
trade & 5 & 2 & 6 & 74 \\
middle class & - & - & 1 & - \\
academics & - & - & - & 5 \\
professionals & - & 1 & 3 & 6 \\
none/unknown & - & 1 & - & 7 \\
sum total & 5 & 4 & 10 & 92
\end{tabular}

\begin{tabular}{llll}
\multicolumn{4}{l}{ Opera $(\mathbf{N}=\mathbf{1 2 0})$} \\
$3 .-$ & $6 .-$ & $15 .-$ & $30 .-$ \\
1 & - & 6 & 61 \\
- & - & - & - \\
- & - & - & 4 \\
- & - & - & 3 \\
- & - & - & 2 \\
1 & - & 6 & 70
\end{tabular}

\footnotetext{
${ }^{24}$ ) We remind readers that the cohorts before ca. 1850 appear to be slightly out of line because of the different measure (rateable value instead of spending or income tax).

${ }^{25}$ ) We tested the relation between the distribution of wealth classes for opera and drama linking the melodrama cohort (1824-1830) to the French Opera cohort (1817-1844). This relation was significant (chi-square $=$ 23.6; $\mathrm{df}=2 ; \mathrm{p}<0.00$ - we had to ignore the first and second class of the melodrama cohort). The distribution of wealth was also significant for the German Opera (1860-1882), Tivoli (1890-1895), and Van Eysden (1902-1912). (Chi-square $=80.0 ; \mathrm{df}=8 ; \mathrm{p}<0.00)$.
} 
Notice that the opera (1789-1792) scored better in the (1803) rateable values (69.2). Its valid percentage in the MTB was 64.2. Drama scored a valid percentage of 70.7 , thus far better than in the rateable values.

We must not suppose a slow decrease of the category 'trade' over time, as table 1a might suggest. The changes are relative to subscription opportunities: from the middle of the century the coupon booklet brought in many more subscribers, and by the end of the century more ranks were open for subscription. The basis for subscription, thus, broadened, which led to a relative lower share for 'trade.' The relation between occupation and wealth categories was, for those cohorts for which it made sense, strong. ${ }^{26}$ Generally all cohorts show the same tendencies in under- and over-representation of job categories by wealth class. For 'trade' and 'academics' there was a strong under-representation in the lower wealth classes and a strong over-representation in at least the fifth wealth class. For 'middle class' and 'professional' occupations this under- and over-representation worked the other way round.

The last cohort, Maifestspiele (1909-1911) is an exception in many ways, but peculiarly relevant for the issue of overall audience characteristics. It concerned a two-week festival, for which most of the tickets were sold by subscription. Even though we have no information on rank, the total amount of subscriptions (677 persons, to which must be added some 160 persons from other cities, who have not been included in the database), related to the house capacity (ca. 1250), suggests that most of the spectators are identified (if every person bought tickets for two there would be some 1675 persons, which the house could not contain). Nine subscriptions from working-class persons indicate that these classes either were hardly interested in this form of theatre, or could not afford it (or both). With respect to job categories and wealth, Paradise was and remained in the theatre stalls.

Money talks: this proverb is relevant for our subscribers. The over-representation of rich merchants, subscribing for first-rank tickets, indeed strongly influenced the other cultural variables. Here, too, the findings for melodrama and opera in the first half of the $19^{\text {th }}$ century are reproduced over the whole period, 1773-1912.

The distribution of social and political functions is given in table $4 \mathrm{a}$ (appendix 3 ). The rate of persons holding functions diminished at the end of the century. The coupon booklets brought in more patrons outside the range of the political and social elite, thus we see a drop in percentages from the $1860 \mathrm{~s}$. With Van Eysden, the cohort had a broader basis in the city population because coupons were sold for more ranks than usual. The difference in functional weight between opera and drama, noticed above with respect to melodrama and opera, also proves structural. More opera-subscribers held averagely more functions than drama-

$\left.{ }^{26}\right)$ Opera: French Opera, 1789-92: no valid Chi-square test; French Opera, 1817-44: Chi-square = 27.6, df = 4, $\mathrm{p}<0.00$; German Opera, 1860-82: Chi-square $=537.7, \mathrm{df}=12, \mathrm{p}<0.00 ;$ Maifestspiele: no ranks known. Drama: Dutch troupes, 1773-92: no valid Chi-square test; Hoedt \& Bingley, 1824-30: almost all data on one rank; Albregt \& Van Ollefen: no valid Chi-square test; Tivoli: Chi-square $=59.2 ; \mathrm{df}=8 ; \mathrm{p}<0.00$. Van Eysden: Chi-square $=629.5$; $\mathrm{df}=12 ; \mathrm{p}<0.00$. 
subscribers. The drama-cohort 1867-1868 stands out, but all its members, except a handful, also subscribed for the German Opera.

Functions and function-holding were biassed for wealth class. Table $4 \mathrm{~b}$ gives the average number of functions per wealth class per $19^{\text {th }}$-century cohort. ${ }^{27}$

Table 4b. Average number of functions per cohort per wealth class $\left(19^{\text {th }}\right.$. c. only)

\begin{tabular}{lllllll}
\hline $\begin{array}{l}\text { wealth class } \rightarrow \\
\text { cohort } \downarrow\end{array}$ & $\mathbf{1}$ & $\mathbf{2}$ & $\mathbf{3}$ & $\mathbf{4}$ & $\mathbf{5}$ & mean \\
$\begin{array}{l}\text { Opera 1817-44 } \\
\text { Opera' 1850-59 }\end{array}$ & - & - & 1.4 & 2.9 & 4.7 & 2.9 \\
Opera 1869-82 & 0.2 & 0.6 & 0.6 & 2.2 & 4.8 & 3.5 \\
Opera 1909-11 & 0.04 & 0.08 & 0.2 & 0.3 & 3.1 & 1.7 \\
Drama 1824-30 & - & - & 0.6 & 1.5 & & 0.5 \\
Drama 1867-68 & - & 0.1 & 0.9 & 1.6 & 4.2 & 1.4 \\
Drama 1890-94 & 0.2 & 0.5 & 0.8 & 1.1 & 1.6 & 1.0 \\
Drama 1902-12 & 0.04 & 0.1 & 0.2 & 0.5 & 1.4 & 0.6
\end{tabular}

All cohorts, then, contain a core of the rich and mighty, a core that proportionally became less 'powerful' in the course of the century, due also to broadening the basis of subscription.

Function-holding tended to cumulate, which shows the nature of merchant elite influence on all fields. Many of the holders of political functions had their hands in economic and financial organisations as well. Moreover, cumulation was also career-bound. A successful political career might well involve some four or five functions: elector, councillor, alderman, burgomaster, member of the provincial estates, member of one of the Chambers of Parliament - that was the full cursus honorum. If one had succeeded to become a councillor, functions of the fixed city committees could follow, as could social and charitable, and military functions (these were often a prelude to a political career, too). Educational functions were to a less extent also tied to political or economic functions. In the course of the $19^{\text {th }}$ century financial functions boomed, since a specific 'financial' elite focussed on banking and particularly on insurance. In order to spread the risks, the elite took part in a growing number of insurance societies, particularly for 'sea and fire risks,' as it was called.

Most of the functions in the $18^{\text {th }}$-century cohorts were held after the revolution of 1795 , thus, later than the early subscription lists. Many of the subscribers were dissenters, who were barred from holding public functions before 1795 (see also below). Their number of functions is suggestive of the potential prestige of the non-aristocratic merchant class. ${ }^{28}$ Table $4 \mathrm{c}$ illustrates that all cohorts had subscribers with high political status.

\footnotetext{
${ }^{27}$ ) The number of functions identified is different from that in table 3a, for we did not find wealth data for all our subscribers.

${ }^{28}$ ) The quick changes in the constitution helped to increase the number of function-holders in the early $19^{\text {th }}$ century, whereas councillors were over and again re-elected in the late $19^{\text {th }}$ century.
} 
Table 4c. Important political functions

\begin{tabular}{llllllll}
\hline & $\begin{array}{l}\text { Drama } \\
\text { 1773-91 }\end{array}$ & $1824-30$ & $1890-95$ & $1902-12$ & $1789-92$ & $1817 / 44$ & $1860 / 82$ \\
$\begin{array}{l}\text { burgomasters/ } \\
\text { aldermen }^{29}\end{array}$ & 4 & 5 & 3 & 6 & 10 & 14 & 15 \\
$\begin{array}{l}\text { councillors } \\
\text { Chamber Commerce }\end{array}$ & 10 & 14 & 22 & 28 & 36 & 41 & 65 \\
Provincial Estates & 2 & 8 & 4 & 8 & 12 & 21 & 10 \\
Batavian Chambers & 5 & 2 & 3 & 15 & 9 & 19 & 25 \\
1st Chamber & 1 & - & - & - & - & - & - \\
2d Chamber & - & 1 & 1 & 1 & - & 3 & 8 \\
Council of State & - & 2 & - & - & - & 2 & 5 \\
consuls/legates & 2 & 3 & 6 & 15 & 4 & 8 & 1 \\
\end{tabular}

The late $18^{\text {th }}$ and $19^{\text {th }}$ century are known as the age of sociability, and table 5a (appendix 3 ) witnesses this. Measuring sociability needs archives, and though some important membership lists are missing for the early and middle $19^{\text {th }}$ century, the proportion of members in those years is still the largest ( 76 to 88 per cent). Both the edges of the period do less well. For the $18^{\text {th }}$ century we lack many data for the smaller and more informal clubs (private reading clubs), as well as those of the important literary society Verscheidenheid en Overeenstemming [Variety and Harmony]. From about 1880 we see the decline of enlightenment sociability and the rise of a more market-based organization of cultural life. Sociability, too, was biassed for wealth, as is shown in table $5 \mathrm{~b}$.

Table 5b. Average number of memberships per cohort per wealth class $\left(19^{\text {th }}\right.$. c. only)

\begin{tabular}{lllllll}
\hline $\begin{array}{l}\text { wealth class } \rightarrow \\
\text { cohort } \downarrow\end{array}$ & $\mathbf{1}$ & $\mathbf{2}$ & $\mathbf{3}$ & $\mathbf{4}$ & $\mathbf{5}$ & mean \\
$\begin{array}{l}\text { Opera 1817-44 } \\
\text { Oppera' 1850-59 }\end{array}$ & - & - & 1.2 & 2.1 & 3.5 & 2.2 \\
Opera 1860-82 & 1.2 & 1.6 & 1.9 & 2.8 & 3.6 & 3.0 \\
Opera 1909-11 & 0.2 & 0.3 & 0.8 & 1.3 & 3.9 & 2.7 \\
Drama 1824-30 & - & - & 0.8 & 1.3 & 2.7 & 1.2 \\
Drama 1867-68 & - & - & 2.2 & 2.7 & 4.3 & 3.0 \\
Drama 1890-94 & 0.6 & 1.4 & 2.1 & 2.7 & 3.9 & 2.6 \\
Drama 1902-12 & 0.1 & 0.4 & 0.8 & 1.6 & 3.3 & 1.6
\end{tabular}

For the Society for the Advancement of Music we have full membership lists in the beginning of the $20^{\text {th }}$ century. In 1911-1912 52.2 per cent of the 402 members went to the theatre (210 members), which percentage was 50.4 per cent in 1913-14 (415 members, 209 theatre goers). In 1865 Harmony had 694 members, of which 53 per cent (369 members) also subscribed for drama and/or opera; a percentage that rose to 56.4 per cent in 1905 (242 of 606 members). Membership lists of the Society for Public Welfare all date quite late. Of 937 members in

29) Burgomasters and aldermen have been added, since the traditional four burgomasters were in the $1820 \mathrm{~s}$ changed into one burgomaster and three aldermen. That would distort the numbers for the early cohorts. 
1883, 527 subscribed for theatre performances (56 per cent); in 1907225 of the 441 members did so (51 per cent). The percentages of these 'elite' societies were, with some fluctuations, normally over 50 per cent. Table 5c (appended) gives a more detailed account of membership and wealth class.

Table 6a (appendix 3) presents data on education and political allegiance. As already noticed, data on education in the period before 1863 are hard to find. Particularly secondary education was opaque. Hence, we only tabulate here data for the cohorts after 1860. Although the outcome may look disappointing, in fact the proportion of subscribers that followed higher, gymnasium or burgher-school education was well above the mean in the city itself. ${ }^{30}$ Later twentieth-century surveys of participation in cultural events often take the MULO as the lowest level of extended education, leading normally the conclusion that theatre and concert audiences were generally educated above the average. The data suggest that this is also true for the $19^{\text {th }}$ century. ${ }^{31}$ Initially, most pupils did not finish the whole course of these new forms of education. In all cohorts this mounted to over 50 per cent of the pupils. Still, this does not mean that they were uneducated. Taken the amount of high-educated subscribers in the first half of the century, and the figures for secondary and higher education after 1863, the assumption of an audience 'with little comprehension' cannot be sustained without new evidence. For now, we reject such a view.

Education also played its role in the discourse of the re-conquest of the stage after 1870. Rössing, the first historian of this movement, particularly stressed that the burgher-schools were the backbone of the re-education of the theatre audience. ${ }^{32}$ Indeed, the burgher-schools focussed on modern languages rather than the classical languages (French, German, and English being obligatory), and often educated their pupils in relatively modern literature. Also, the practise of school drama performances returned. We agree, even on the basis of this slim evidence, that the subscribers in the cohorts around 1900 were well over-average educated, but with respect to the small impact of the burgher-schools both in the cohorts and in the population at large, we think it overdone to say that the burgher-schools were a decisive

$\left.{ }^{30}\right)$ N.L. Dodde, Tot der kinderen selfs profijt. Een heschiedenis van het onderwijs te Rotterdam (Den Haag, 1991), states that the proportion of pupils in the new extended education system between 1865 and 1900 was negligibly small (p. 217), and estimated that only 8 per cent of the city population could even consider to send their children to such schools (p. 231). He calculated that 2 per cent of the boys of 12-17 years of age visited the gymnasium (1825-1880); 3 per cent of that age group visited the HBS-5 at the end of the century, and 2 per cent of that age group visited the HBS-3 about 1880 (pp. 229, 234, 241).

$\left.{ }^{31}\right)$ See for an overview of the twentieth-century surveys: H. Ganzeboom, Cultuurdeelname in Nederland (Assen, 1989); W. Knulst, Van Vaudeville tot Video (Rijswijk, 1989); H. van Maanen, Het Nederlands toneelbestel (Amsterdam, 1997).

${ }^{32}$ ) The idea was already current about 1916, when Rössing used it in his De Koninklijke Vereeniging Het Nederlandsch Tooneel (Amsterdam, 1916). Robert H. Leek, Shakespeare in Nederland (Zutphen, 1988), returns to it (p. 95). 
factor. To decide that, far more data are needed documenting the share of cultural education in boarding schools, the $M U L O$, cultural societies, or at home.

We also hypothesised that, due to the census voting system, the wealthy theatre goers would show most active interest in politics. They did, but with a strong bias, first for democratic Patriotism, and later for liberalism (table 6a, appendix 3). The data for political allegiance were strongly biassed due to the fact that only liberal election clubs left membership lists. These cover the period 1869-1882. Officials and candidates of conservative and christen-democrat election clubs were listed in the address books, election-advertisements in journals, and newspaper reports on political meetings, but their numbers are a fraction of the liberal counts. It is no surprise, hence, that liberal allegiance dominates the later $19^{\text {th }}$ century cohorts. Yet, this dominance is not fully due to archival bias. The conservatives, the former aristocratic regents, always formed a small fraction that had its Indian summer in neoabsolutism (1814-1848). About the same counts for conservative liberals, successors of the 'moderates' of the Batavian Republic. Both, moreover, often merged with what were later to become the religion-based parties. There, a strong resistance against theatre going was traditional. This tended to increase in the later decennia of the $19^{\text {th }}$ century, due to the intensification of cultural differences, the Dutch form of the German Kulturkampf, known as the 'pillarisation-process.' Only a very few conservatives and christen socialists who ran for elections can be found among the subscribers, even if they fitted the profile of theatre-goers in status, occupation and wealth.

With respect to political allegiance, we envision a continuity of what was already noticeable at the beginning of institutionalised theatre culture. The founders of the theatre were deeply involved in Patriotism (60 to 70 per cent of the two societies of shareholders were Patriots and only the second society of shareholders counted 8 per cent Orangists). ${ }^{33}$ In both drama and opera cohorts, ancien régime councillors of both Patriot and Orangist allegiance, both before and after the coupe-year 1787 were practically absent, even while the French Opera performed at the Stadtholder's court in Breda in the time of the Orange Restoration (1787-1795). There appears to have been a culture cleft between the theatre (at which the city government frowned from the beginning) and the chic concert series in the Bierstraat, in the former home of the Orangist councillor Cornets de Groot. There are subscription lists for these concerts for exactly the same years as the Rotterdam French Opera (1789-92). In the

\footnotetext{
${ }^{33}$ ) The opposition 'Patriot' against 'Orangist' is in some ways misleading. In fact three parties were relevant: The Orangists, the democratic Patriots and the aristocratic regents, formerly the anti-stadtholder segments of the regents ('Estates-minded' regents). Perhaps, as a fourth force we must count in the enlightened regents, who collaborated with the democrats before 1795. Many of the democratic Patriots in fact envisioned a unified monarchy under the House of Orange, but disappointedly had to swallow the fact that in 1787 the Stadtholder made himself a vassal of the Prussians and English, forcing many of the aristocrat regents to his side. Hence, in 1795 his position had become irrelevant for both Patriot democrats and aristocrats. See C.H.E. de Wit, De strijd tussen Aristocratie en Democratie in Nederland, 1780-1848 (Heerlen, 1965) and De Nederlandse Revolutie van de Achttiende Eeuw, 17801787. Oligarchie en Proletariaat (Oirsbeek, 1974). The relevance of an opposition between Patriots and Orangists, meaning the aristocratic party forced to join the Stadtholder, is the greatest in the period 1787-1795.
} 
Bierstraat 24 Orangists gathered (42 percent of the cohort of 56 subscribers) against one Patriot (quite some adolescent children of Orangist regents subscribed here, too). ${ }^{34}$ Of the 120 subscribers for the French Opera, 1789-92, eleven were to become a member of the moderately democratic-revolutionary Gemenebestgezinde Burgersociëteit [Common Wealth $C l u b]$ and two in the club of the 'Rotterdam Jacobines,' the Sociëteit van Volksvrienden [Society for People's Fraternity], which counts for their active involvement in the Revolution of $1795 .{ }^{35}$ The drama cohort, 1773-92 counted four members of the moderate club. Without stating that democratic Patriotism automatically developed into liberalism (though often it did), there is a strong suggestion that the attitude towards culture of both political-ideological movements was the same, and was based on the ethics and aesthetics of the Enlightenment theatre. Disinterest in theatre-going (except, perhaps the Royal French Opera in The Hague), is manifest in the old regent caste, continuing in the anti-theatrical prejudice of the orthodox regents into the Restoration era and beyond, first as conservatism and later as Christiansocialism, particularly the Anti-Revolutionaries and the Catholics.

Our conclusion is that the hard core of the theatre audience from the ancien régime to the days of women's lib was wealthy and trade-based. The city (merchant) elite was as much 'compromised' in the culture of melodrama as it was later to become in naturalism and early symbolism - in fact it often concerned successive members from the same families. Taste evolved, but the social composition of the audience remained stable with respect to occupation, wealth, power, sociability, education, and political 'liberalism.' Differences in data are rather due to lack of archives, than to real differences, or to the broadening of subscription opportunities, which tend to relatively diminish the impact of the merchant class.

\section{An Overview of the Implicit Social Variables of the Subscribers, 1773-1912}

Besides the explicit variables relevant in the traditional theatre historiography, there are some implicit variables of theatre-going which were neglected in it. We consider three of them: religion, woman, and age.

Religion is relevant for pre-twentieth-century theatre-going because of the anti-theatrical prejudice in Calvinism, the official religion of the country. From the origin of commercial theatre in the early seventeenth century, orthodox Protestants agitated against theatre as being the very pomps of the devil, and from the first they were opposed by more liberal Protestants, particularly Arminians, who saw no evil in decent theatre. As such, theatre tended to become an issue between Estate-minded regents (lenient), and Orangist regents (severe). Lenient

\footnotetext{
${ }^{34}$ ) In fact, the members also could join the orchestra. The 1773 'Venrooy society' the members also joined the orchestra, but this society consisted of later 'Patriots.' Elite amateurs still joined the (now mainly 'professional') orchestra during the $19^{\text {th }}$ century. See also Chapter \#\#.

${ }^{35}$ ) Unfortunately no membership list survived of the 'Jacobine' club so that only some five members could be traced.
} 
Estate-minded regents, supported by Arminians stood at the basis of the short-lived Rotterdam theatre (1631) and supported the performances given by Jean Baptiste van Fornenbergh and Jacob Sammers in Abraham Boschman's Tennis Court at the Kipstraat during the first stadtholder-less period (1650-1672). Support for theatre, from this angle was lasting. As table 3a (appendix 3) shows, both in opera but particularly in drama Arminians were and remained strongly over-represented in the theatre as compared to their position in the city. Their impact in the first shareholders cohorts $(1773,1780)$ was even greater: 37 per cent of the first shareholders and 44 per cent of the second were Arminians. Rich merchant families like Van Rijckevorsel, Van der Hoop, Havelaar, and Burger were among the staunch sponsors of a standing theatre.

The French Church ('Walen'), too, was well over-represented in the theatre, particularly in the opera cohorts. At the end of the seventeenth century these 'Huguenots,' part of the official religion, had often been stern Calvinists, but in the $18^{\text {th }}$ century they became a major force in patronage of particularly music theatre. Mennonites followed them, as did part of the Lutherans. Restrictions to Jews were repealed after the 1795 Revolution, but it took about three generations before Jews participated regularly in the subscription lists. The later $19^{\text {th }}$ century witnessed a boom of Jewish patronage. Best known in Rotterdam were the bankers' family Ezechiel and the merchant family Jacobson. Louis Pincoffs, who caused the largest bankruptcy scandal in Rotterdam's history (1879) was surely the most notorious. The Van den Berghs, who stood at the basis of Unilever, moved to Rotterdam in the early 1890s.

Roman Catholics, who supported the early opera troupes quite well, withdrew in the course of the $19^{\text {th }}$ century. The Restoration era showed a tendency to keep Catholics out of public offices. Their subsequent struggle for emancipation, led tot the re-institution of bishoprics in 1853, and from 1868 onwards to an ideological struggle with liberalism, due to the Pope's bull against Liberalism. In its wake, Catholic leaders discouraged theatre-going among their flock, which is indirect evidence for the extent to which a standing theatre was considered a liberal institution. Until about the Great War, the Catholic journal Maasbode refused to review theatrical shows, and opposed every attempt at municipal subsidy for the theatre. With respect to theatre, Catholic politicians for a long time sided with antirevolutionary Protestants, who, of course, had a history of theatrical prejudice. Both the Roman Catholic and the Dutch Reformed denominations were under-represented in the cohorts; Roman Catholics more so than Dutch Reformed. Table 3a shows that the city became slowly more protestant. This was to a large extent the result of migration to the city from the protestant country side. ${ }^{36}$ The division of religions over cohorts is not due to chance. ${ }^{37}$

\footnotetext{
${ }^{36}$ ) There is some debate on the background of migrants to Rotterdam, which were traditionally supposed to have come mainly from Catholic Brabant. The municipal yearly reports, which have been used in table 3a clearly show that this cannot be true. West Brabant had a strong protestant minority as well.

${ }^{37}$ ) We had to leave out the $18^{\text {th }}$-century drama and opera cohorts, because they contained no Jews. Also we had to leave out the Mennonites, whose share before ca. 1870 was too small, and the category 'none' and 'unknown,'
} 
With respect to wealth, the two largest denominations (Roman Catholics and Dutch Reformed) were under-represented in the highest wealth class and often over-represented in the lower classes. For Arminians and French Church, this pattern was reverse. Lutherans and Jews formed more of a ragged pattern. In the course of the $19^{\text {th }}$ century the tendency increased to change religious allegiance. Particularly the Dutch Reformed Church lost members to the smaller denominations with a higher status (French Church, Arminians). Noteworthy is the growing proportion of those who left the church. As table 3 a shows, nondenominationality increased slowly, accelerating at the beginning of the twentieth century, but the rate was quite higher for theatre-goers than for the city population in general. religion counted, if only for the theatre's demon other. The hypothesis that religion was a relevant variable proved correct. The more orthodox denominations, particularly the Dutch Reformed, were under-represented, whereas the more liberal Protestant denominations were over-represented. These small denominations also were more wealthy. We had not expected that the Roman Catholics responded so negatively to the theatre.

The subscription lists, particularly those before 1860, suggest that the audience was predominantly male. However, from the beginning of the regular seasons (1773), some women independently subscribed for tickets. Their numbers are given in table 1c.

Table 1c. Number of women subscribers and percentage in the cohorts

\begin{tabular}{llllll}
\hline Opera & number & percentage & Drama & number & percentage \\
$1789-92$ & 2 & $1,7 \%$ & $1773-92$ & 8 & $5,1 \%$ \\
$1817-44$ & - & - & $1824-30$ & 3 & $1,2 \%$ \\
$1860-82$ & 48 & $4,1 \%$ & $1867-68$ & - & - \\
$1909-11$ & 106 & $15,7 \%$ & $1878-00$ & 20 & 5,5 \\
& & & $1890-95$ & 43 & $7,4 \%$ \\
& & & $1902-12$ & 228 & 15,4
\end{tabular}

Table 1c shows a slow increase of women independently subscribing, climbing from less then 2 per cent before 1850 , to about 5 per cent in the 1860 s to some 15 per cent in the $1910 \mathrm{~s}$. The relative high figure for women at drama, 1773-1792 is due to an exceptional subscription in 1778-79. The theatre would be closed if it did not get 300 subscribers and hence, some shareholders had their wives and daughters subscribe independently.

Such small figures, however, are misleading, for male subscribers took regularly more than one ticket. Sometimes they had to state explicitly that these were for women for often women could enter cultural events at bargain prices when accompanied by a man. In other cases we are not sure that the extra tickets were for wives and daughters, but the number of extra tickets then gives at least an upper limit of the number of female companions. Table 1d enumerates the numbers of extra tickets taken by subscribers for the cohorts before 1860 . We

since these contained empty cells. English, Scots and Reformed dissenters, were counted with the Dutch Reformed, as 'Protestants.' Chi-square $=117.7, \mathrm{df}=30, \mathrm{p}<0.00$. 
had to calculate numbers from the original lists and, hence, had to split the macro-cohorts. The lists of coupon subscriptions do not specify the number of persons for whom tickets were bought. Hence, there are no specified data after 1860.

Table 1d. Number and ratio of accompanying women to male subscribers

\begin{tabular}{llllll}
\hline Opera & number & male-female ratio & Drama & number & male-female ratio \\
$1789-92$ & 30 & .25 & $1791-92$ & 6 & .24 \\
$1817-20$ & 40 & 1.08 & $1824-30$ & 16 & .6 \\
$1836-38$ & 195 & .94 & & &
\end{tabular}

The numbers give extra seats reserved by male subscribers and the male-female ratio gives the proportion of these extra tickets related to the number of male subscribers. Notice that in the years 1817-1820, the number of women in the boxes of the French Opera was probably larger than that of male subscribers and therefore is over 100 per cent.

It is clear enough that opera was far more a family outing than Dutch drama, and that the potential number of women taken to the theatre was lowest in the 'melodrama years.' This might confirm what critics remarked: a decent person could not take his wife to the theatre because of the piquance in the plays, and, perhaps, the presence of prostitutes in the pit. ${ }^{38}$ The three independently subscribing women in the 1824-1830 cohort were the widow of an English merchant in Rotterdam, a Jewish female merchant in cottons, and a widow letting masquerade costumes.

After 1860 a few patrician merchants' wives subscribed independently on guarantee lists of the German opera, whereas more women bought coupons for the drama. Quite often they ran a shop or a coffee house or worked as teachers, though widows without occupation or resident daughters also signed for coupons by the end of the century, some widows remarkably short after their husbands decease. At the end of the century wives quite often signed for the coupons, which their husbands payed. There are more signs that women took an active interest in the household's cultural affairs. Not only do we find some women members in usually all-male cultural societies, but also anecdotes and other indices point to it. A harbour baron wrote to the managers of the Tivoli theatre not to carry out their plan to install lights in the baignoires: his wife wanted to see the play, but he himself would be happy to take a nap in the dark box. ${ }^{39}$ The 1894 yearly report of the Art Circle [Kunstkring], an elite society, complained of the fact that Rotterdam merchants preferred light entertainment to high art, so that the concerts suffered a 75 per cent women audience. The growing emancipation obviously was not cheered by all.

\footnotetext{
${ }^{38}$ ) See the NRC, 1844, nr. 128 (October 5), and nr. 145 (October 22).

${ }^{39}$ ) We owe this anecdote to of Wim Achten, who is writing a book on the Tivoli Theatre.
} 
Age also is a relevant, but neglected, variable. As we noticed above, subscribers could mainly consist of elder persons who had made it, or of their late-marrying sons. McConachie, for instance, saw 'waning patriarch' at melodramas, hence, frustrated elderly men. The satirical description of Rotterdam, De Physiologie van Rotterdam (1844), however, stated that the merchant elite's sons, who married at about thirty years of age, infested the theatre. ${ }^{40}$ The mean age of the cohorts could not be calculated for all persons, since we did not always know the date of birth. Table $2 \mathrm{a}$ presents the results; table $2 \mathrm{c}$ (appendix) gives a more detailed overview.

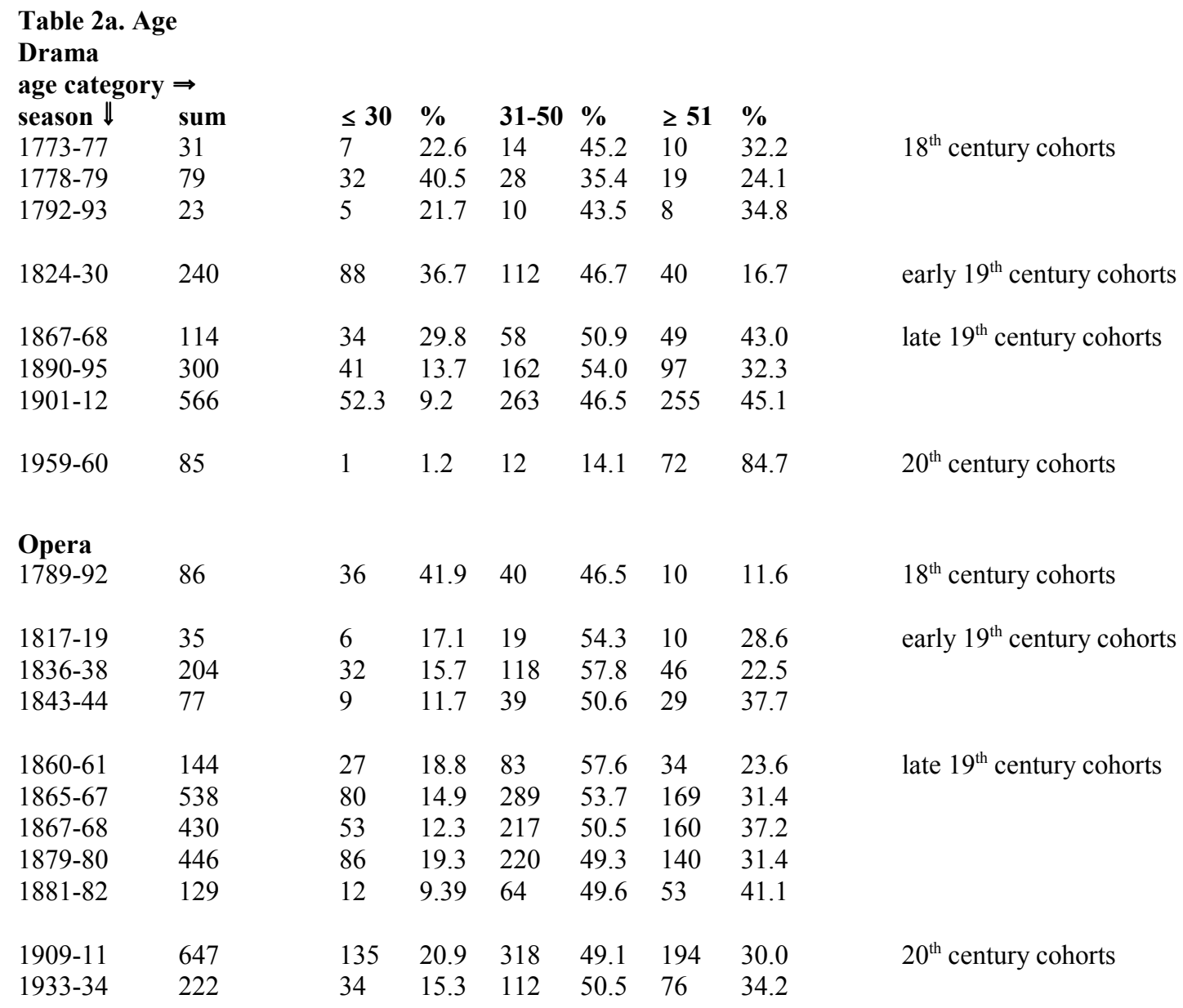

In table $2 b$, the number of subscriptions divided by the number of subscribers establishes the mean number of seasons in which subscribers participated. This is a static indication of subscribers' loyalty. Table $2 \mathrm{~b}$ also specifies the valid counts, the number of subscribers from which the age could be calculated. In the oldest cohorts that number was considerable lower

$\left.{ }^{40}\right)$ Physiologie van Rotterdam (Den Haag, 1844), I, p. 121; II, p. 66. 
than in the later ones. The small aggregated cohorts were not subdivided into seasons to avoid empirical emptiness. ${ }^{41}$

\begin{tabular}{lllll}
\multicolumn{2}{l}{ Table 2a. Average Frequency } & & & \\
& subscriptions & subscribers & $\begin{array}{l}\text { mean participation } \\
\text { per subscriber }\end{array}$ & valid counts \\
opera, 1789-92 & 120 & 120 & 1 & 86 \\
opera, 1817-44 & 326 & 276 & 1.2 & 316 \\
'opera' 1852-59 & 134 & 134 & 1 & 133 \\
opera, 1860-82 & 1748 & 1150 & 1.5 & 1686 \\
drama, 1773-92 & 182 & 157 & 1.2 & 130 \\
drama, 1824-30 & 451 & 253 & 1.8 & 240 \\
drama, 1867-68 & 115 & 115 & 1 & 114 \\
drama, 1890-95 & 1534 & 582 & 2.6 & 1503 \\
drama, 1902-12 & 5863 & 1476 & 3.9 & 5654
\end{tabular}

For opera the tendency to participate in more than one season is much smaller than for the later drama cohorts.

Today there is much discussion on the topic of 'greying audiences,' but $19^{\text {th }}$-century subscribers also were averagely old. It seems, hence, that not much has changed with respect to loyal patrons. Not only was the percentage of those under thirty small, but the percentage of those over fifty quite large. Two exceptions earn to be mentioned: The demographic structure of the melodrama cohort is very far from McConachie's assertion about waning patriarchs. Since most of the subscribers had a proper occupation, they also cannot be regarded as the idle elite youngsters of the Physiologie van Rotterdam asserted. With respect to the repertoire of Hoedt \& Bingley the demographic structure of the cohort is interesting and might raise the hypothesis of melodrama was a part of the 'progressive' culture of the post-revolutionary generation; melodrama as a 'provocative' or 'innovative' form of theatrical amusement and therefore the object of cultural contest. The cultural elite, which overtly contested melodrama in theatre journals, to be sure, was often also quite young so in that respect the late $18^{\text {th }}$ century battle between comédie larmoyante and neo-classical drama was pursued by the next generation, and, perhaps, these are just phases of the matrix of all debates on theatre (for, or against 'innovation,' which always involves ethics and ideology).

This result made us speculate about the function of melodrama and youth culture. The $N R C$ noticed in 1844 that many 'children' frequented the pit. But what about the gallery? We know from Mendes da Costa's Memories of the Stage (1900), referred to in our dangerous speculations, and to be discussed more fully below, that he, a student, frequented the gallery, if he was short of money. Might it no be likely that theatre historians focus too much on theatre ranks as class division, neglecting age-division? There has been much study of the links of melodrama and cinema with respect to content. Might it not have been also a matter of age? Early cinema has often been regarded as a cultural niche for youths, whereas the

\footnotetext{
$\left.{ }^{41}\right)$ The 1824-30 cohort was not treated as a complex cohort. Calculations have been made here 'by hand.'
} 
theatre after the process of 'elevation' became more effectively hostile to melodrama: it slowly died out or was used explicitly for the working class ('popular performances'), but it is well-known that the elite as well as theatre historians spoke of the gallery audiences there as 'the servant maid and her sailor-man,' likely young folk. Popular cinema (on TV or not) still might relate the taste of youngsters with the taste of the lower middle classes, even while both groups today hardly meet each other any more, either on the three-seater or in the lobby of a film-palace. The fare, though is comparable: exciting horror, sex, and violence. Present-day cinema-patrons are mainly teenagers, thus, why not should the companies of a Hoedt and Bingley, or a Valois not have provided exiting entertainment in the otherwise rather dull cities. They were despised for their repertoire by highly elite critics, but the managers knew that the elite was a minority in theatre-patronage, and, as the melodrama season-ticket list points out, the elite - as today - also enjoyed excitement now and then. From 1835 onwards, the theatre structurally lost its gallery audience, and from the mid 1870s, a large part of its pit audience, too. Who were they, and whereto did they go. Likely to entertainment that was comparably exciting, as for instance in the amateur theatres and the vaudeville, which was cheaper, and mostly gay (mainly in the straight sense). One could drink and smoke during the shows, and felt not despised by the 'upper class' nor re-educated to high culture. Another advantage was the offering of short pieces, which made it more easy to come and go. For office clerks and trade agents, the free-entry hotel-related 'salons' catered best for the coming and going man, as it advertised its list of songs and sketches, and the expense was only that you had to consume some drinks. Perhaps we under-estimate that the young - just like now sought excitement, and before about 1855 mainly the theatre provided it. After 1860 the structure of the market of theatrical entertainment became much more complex. That gave the elevators of the stage new opportunities - particularly for the rather old.

For, the second aspect is the old audience for Van Eysden and for Albregt \& Van Ollefen (1867-68). The 31-51 years of age subscribers took some 45 to 51 per cent, but the percentage of over 51 years of age reached to some 43-44 per cent. (It was some 17 per cent in the melodrama cohort). In view of the size of the 1867-68 cohort, the situation might be exceptional, but Van Eysden catered for a grey- or bald headed stalls. Again, that may lead to hypotheses of his repertoire (and the critical reception of it). The demographic and social composition of his audience may well have been a factor in the difficulties Van Eysden encountered with modern plays, and therefore, with his reputation in theatre history. ${ }^{42}$

The increase of aging in the middle century was not particularly due to continuity. Of 253 subscribers for the melodrama years, 172 only participated in that cohort. Only four of them still subscribed for Albregt in 1867-68. Some five subscribers for Le Gras in the 1870s

42) The minutes of the shareholders, 1905-1913, Municipal Archive Rotterdam, Rotterdamsch Tooneelgezelschap (inv. Nr. 175), nr. 1 repeatedly reports the problem that the 'elite' could not be persuaded to see even Ibsen. Plays by Shaw or Schnitzler were not appreciated neither. 
and some twenty in the 1880 s continued play-going in the $1890 \mathrm{~s}$ and $1900 \mathrm{~s}{ }^{43}$ The overlap of the subscribers for Le Gras in the 1890s, Tivoli, and Van Eysden was as might be expected, much larger, for these cohorts partly overlapped in time. Such a partly synchronic overlap does not cause aging.

\section{Differentiation per Rank}

The traditional narrative of audience composition in the long $19^{\text {th }}$ century shows a tendency to equate social class and rank. Indeed, many $19^{\text {th }}$-century essayist has pictured the gallery as the domain of apprentices, servants, sailors, and working class persons, and juxtaposed it against the economic elite in the stalls and balcony. Descriptions of audience behaviour on the different ranks invited such a classification. Indeed, when kissing sounds are heard or soubrettes are yelled at from the galleries, its patrons swerve far from bourgeois mores. Is there a 'real' class division per rank?

For drama this relation is far more outspoken than for opera. For reasons of space we only compare German Opera, 1860-1882, with Dutch-spoken drama, 1902-1912 (table 1b, appendix 3). The first rank of the Opera (balcony and stalls) just counted more very rich merchants and academics than the second rank (boxes and parquet) and the third (pit). In the pit, the third and fifth wealth classes were rather evenly spread for these occupations. 'Middle class' occupations and 'professionals,' grouped on the third rank, and in the second and third wealth classes. We surmise that this difference between the job categories 'trade' and 'academics' on one hand, and 'middle class occupations' and 'professionals' is due to the income structure in the city.

Van Eysden shows a clear change per job category, per income class, per rank. Classfive merchants dominate the first rank, whereas their pit-fellows are predominantly found in the second and third wealth classes. The pattern of decreasing rank, relating to decreasing wealth is particularly clear with the 'professionals.' The large number of high-income firstrank drama patrons without a profession consisted to a large extent of the unmarried patrician daughters (the spinster-sisters Rueb, Van Reesema, Van Rossem, and so on). It must be recalled that the third rank was a bit exceptional, since - due to acoustics - it provided a bargain price for what in fact was a first rank (balcony).

In the German Opera, merchants are the largest group in all three ranks. At the Dutch drama of Van Eysden, 'middle-class' occupations were the largest group on the third rank (though 'professionals' almost equalled them). 'Professionals' dominate the fourth rank (pit), followed by 'middle-class' occupations at some distance. ${ }^{44} \mathrm{We}$ also inspected the French

\footnotetext{
${ }^{43}$ ) Not all names of the subscribers for Le Gras could be identified, so that we cannot give exact numbers.

44) In the cohort German Opera the 277 coupon buyers of 1879 , for which we had wealth and occupation data, but no rank, have been left out of consideration here, since rank is pertinent in this discussion. It concerns here
} 
Opera (1817-1844) and Tivoli Theatre (1890-1894), which showed a more skewed though not radically different distribution. ${ }^{45}$ Thus, there are differences in rank, wealth, and occupation in both opera and drama, but they are more pregnant for drama. Overall, these differences concern different bourgeois occupation categories. Working class persons hardly played a role (if any, only at drama), and were moreover, distributed over three ranks.

With respect to 'age' a calculation per rank did not make sense for all cohorts. The $18^{\text {th }}$ century and melodrama cohorts for instance consisted predominantly of subscribers for the pit. For such macro-cohorts as the French Opera 1817-1844 or the German Opera 1860-1882 the calculation of the mean age would, due to the spread of the cohort in time, lead to distortion rather than insight. At Van Eysden's Dutch drama, most participants belonged to the age-class 41-50 years, on all ranks but the pit. In the pit the age-class 31-40 years was the largest. Proportionally the first, third, and fifth ranks showed more age difference than the second and fourth ranks, as is shown in table $2 b$ :

Table 2b. Proportional distribution of age-classes to rank, Van Eysden, 1902-1912

\begin{tabular}{llllll}
\hline $\begin{array}{l}\text { rank } \rightarrow \\
\text { age-class } \downarrow\end{array}$ & $\mathbf{1}$ & $\mathbf{2}$ & $\mathbf{3}$ & $\mathbf{4}$ & $\mathbf{5}$ \\
$11-20$ & 1.5 & 4.7 & 1.9 & 7.2 & 8.3 \\
$21-30$ & 13.9 & 21.1 & 13.3 & 18.3 & 11.0 \\
$31-40$ & 19.6 & 21.6 & 25.4 & 25.6 & 29.7 \\
$41-50$ & 27.8 & 25.4 & 36.0 & 19.8 & 31.0 \\
$51-60$ & 24.1 & 21.8 & 15.7 & 19.1 & 14.5 \\
$61-70$ & 10.9 & 4.3 & 7.0 & 7.9 & 5.5 \\
$71-80$ & 2.3 & 1.0 & 0.7 & 2.1 & -
\end{tabular}

The pit and upper boxes had a slightly younger audience than the other ranks, while the first rank tends more to a middle-age patronage. The differences were, however, small and the distribution was not statistically significant. ${ }^{46}$

persons who only subscribed for this season (otherwise they would have been put on a rank in another season). Their distribution in wealth classes and job categories corresponded with the identified subscribers.

${ }^{45}$ ) The first Coolsingel Theatre had a small second rank. Hence, most of the subscribers sat in the pit or the also not very large boxes. Merchants were the largest group on all three ranks. Of those in the boxes (47 persons), 42 were in the fourth or fifth wealth classes (26 in the fifth), whereas 67 of 86 merchants in the pit were in the third or fourth wealth classes ( 31 in the third). The bulk of the academics ( 28 out of 35 ) sat in the pit, where 12 were in the fourth, and 11 in the fifth wealth class. The weight of the middle class occupations and professionals were in the third wealth class (18 out of 37). There were no subscribers in wealth classes one and two. In the Tivoli Theatre so many subscribers (for three ranks categories) took first-rank tickets, that the distribution was rather uneven. Merchants were the largest group on all ranks. The category 'trade' showed more of a ragged pattern, but the other job categories clearly showed that the cheaper the rank, the less the wealth class. For the $18^{\text {th }}$-century cohorts the wealth data either did not discriminate sufficiently (most were in the highest class of the burial tax), or yielded too few data (rateable values, which were also quite later than the subscriptions). In the melodrama cohort, 1824-1830, only seven out of 205 subscribers for which we found wealth data sat in other ranks than the pit.

46) A chi-square test gave the following results: chi-square $=21.3 ; \mathrm{df}=16 ; \mathrm{p}<0.17$. For this test we had to merge the first two and last two age classes. 
Table $4 \mathrm{c}$ gives the distribution of function categories per rank per wealth class for the German Opera (1860-1882) and for Van Eysden (1902-1912). Function categories cumulate (one person can score in more function categories). The number of functions differs from that in table $4 \mathrm{a}$, since we did not find wealth data for all subscribers. The distribution in both cohorts is not due to chance. ${ }^{47}$

\section{4d. Rank, Wealth Class and Function Categories}

\begin{tabular}{|c|c|c|c|c|c|c|c|c|c|c|c|c|}
\hline \multicolumn{7}{|c|}{ German Opera, 1860-1882 } & \multicolumn{6}{|c|}{ Drama, Van Eysden, 1902-1912 } \\
\hline class & 1 & 2 & 3 & 4 & 5 & sum & 1 & 2 & 3 & 4 & 5 & sum \\
\hline rank 1 & - & 3 & 3 & 72 & 488 & 566 & 1 & 3 & 50 & 78 & 548 & 680 \\
\hline rank 2 & - & 6 & 20 & 65 & 186 & 277 & - & 9 & 16 & 12 & 7 & 44 \\
\hline rank 3 & - & 36 & 88 & 96 & 161 & 381 & 2 & 4 & 4 & 3 & 1 & 14 \\
\hline rank 4 & \multirow{2}{*}{\multicolumn{6}{|c|}{ not available }} & - & 5 & 3 & - & - & 8 \\
\hline rank 5 & & & & & & & - & - & - & - & - & - \\
\hline missing & 1 & 24 & 25 & 97 & 141 & 288 & & & & & & \\
\hline Sum & 1 & 69 & 136 & 330 & 976 & 1512 & 3 & 21 & 73 & 93 & 556 & 746 \\
\hline
\end{tabular}

At the German Opera, first-rank patrons held an average of 3.2 functions; at the second rank this was 1.9, and on the third rank 1.2. At the drama of Van Eysden, first-rank patrons held 0.9 functions, second-rank patrons 0.2 , third-rank patrons 0.2 , and fourth-rank patrons 0.04 . The fifth rank did not hold any functions. It is thus also true, particularly for the drama, that more functions were hold when the price of the seat increased, and that involved occupation and wealth.

Table 5c shows the distribution of sociability categories per rank per wealth class for the German Opera, 1860-1882 and for Van Eysden, 1902-1912. Membership categories cumulate (one person can score in more categories of societies). The number of functions differs from that in table 5a, since we did not find wealth data for all subscribers. The distribution in both cohorts is not due to chance. ${ }^{48}$

$\left.{ }^{47}\right)$ Data from table 4a. Opera, 1860-1882: Chi-square $=305.9 ; \mathrm{df}=9$; $\mathrm{p}<0.00$. Drama, 1902-1912: Chisquare $=298.1 ; \mathrm{df}=6 ; \mathrm{p}<0.00$. We had to add up the two lowest wealth classes, and rank 3 to 5 , due to empty cells, a fact that hinders such tests for other cohorts. It was also not very useful to give all results in table, since in the older cohorts one rank often dominated (the pit). For the French Opera 1817-1844 the results were also significant, with a good distribution of data in wealth classes three to five: chi-square $=107.6 ; \mathrm{df}=4 ; \mathrm{p}<0.00$.

48) Opera, 1860-1882: Chi-square $=526.8 ; \mathrm{df}=9 ; \mathrm{p}<0.00$. We had to add up wealth the two lowest wealth classes. 3.2; $\mathrm{df}=8 ; \mathrm{p}<0.00$. We had to add up rank 3 to 5 , due to empty cells, a fact that hinders such tests for other cohorts. It was also not very useful to give all results in table, since in the older cohorts one rank often dominated (the pit). 
Table 5c. Rank, Wealth Class and Sociability

\begin{tabular}{|c|c|c|c|c|c|c|c|c|c|c|c|c|}
\hline \multicolumn{6}{|c|}{ German Opera, 1860-1882 } & \multicolumn{7}{|c|}{ Drama, Van Eysden, 1902-1912 } \\
\hline class & 1 & 2 & 3 & 4 & 5 & sum & 1 & 2 & 3 & 4 & 5 & sum \\
\hline rank 1 & - & 3 & 16 & 125 & 597 & 741 & 4 & 13 & 133 & 257 & 1270 & 1677 \\
\hline rank 2 & - & 14 & 71 & 112 & 213 & 410 & 4 & 27 & 82 & 41 & 36 & 190 \\
\hline rank 3 & 4 & 71 & 193 & 168 & 203 & 639 & 1 & 8 & 14 & 21 & - & 44 \\
\hline \multicolumn{7}{|c|}{ rank 4 not available } & 2 & 25 & 23 & 6 & 1 & 57 \\
\hline \multicolumn{7}{|c|}{ rank 5 not available } & 1 & 5 & 2 & - & - & 8 \\
\hline missing & 2 & 68 & 80 & 227 & 221 & 598 & & & & & & \\
\hline Sum & 6 & 156 & 360 & 632 & 696 & 2388 & 12 & 78 & 254 & 325 & 1307 & 1976 \\
\hline
\end{tabular}

In the German Opera, first-rank patrons held an average of 4.2 memberships; at the second rank this was 2.9, and on the third rank 2.1. At the drama of Van Eysden, first-rank patrons held 2.3 memberships; second-rank patrons 0.7 , third-rank patrons 0.05 , fourth-rank patrons 0.4 , and fifth rank patrons 0.4 memberships. It is thus also true, particularly for the drama, that more memberships were held when the price of the seat increased, and this implied an impact of occupation, wealth, and function holding. The drama cohort shows a dramatic skewness. Sociability in opera cohorts was more evenly divided over all ranks, in comparison with the later drama cohorts (the $18^{\text {th }}$-century and melodrama cohort predominantly subscribed for the pit). Yet, the decrease of average memberships is significant.

Table $6 \mathrm{~b}$ gives the percentages of persons per cohort, for which we found data on education. Both per rank and per wealth class the number of 'educated' decreases when the rank is 'lower' or the income smaller for those cohorts which fell within the range of the new education system:

Table 6b. Percentages of higher education data per rank and per wealth class

\begin{tabular}{llllllll}
\hline $\begin{array}{l}\text { cohort } \rightarrow \\
\text { rank } \downarrow\end{array}$ & Tivoli & Eysden & Maifest & Class $\downarrow$ & Tivoli & Eysden & Maifest \\
rank 1 & 30.2 & 26.2 & & class 1 & 4.2 & 4.7 & 15.7 \\
rank 2 & 10.2 & 13.2 & & class 2 & 21.7 & 14.4 & 19.6 \\
rank 3 & 4.3 & 12.8 & & class 3 & 17.1 & 17.9 & 22.3 \\
rank 4 & & 0.0 & & class 4 & 28.8 & 27.8 & 26.9 \\
unknown & 12.5 & & 25.0 & class 5 & 30.3 & 28.3 & 35.3
\end{tabular}

The relation between wealth class and education is not due to chance. ${ }^{49}$

It turns out that occupation (trade), wealth, function-holding, sociability, and education are strongly linked with rank. It must be stressed that all such differentiations were in the bourgeois class, and had at best to do with the differentiation 'trade/academic' occupation categories versus 'middle class/professional' occupation categories. 'Objective' class

${ }^{49}$ ) We tested the relation with a Kruskal-Wallis test: $\mathrm{H}=12.17$; $\mathrm{df}=4$; $\mathrm{p}<0.00$. We did not test the relation between rank and education, since there were no data for the Maifestspiele and an empty cell (Van Eysden, rank 5). 
differences per rank are very weak - the few working class persons we detected were not even on the same (low) rank.

\section{A Stable Background}

The traditional dominant narrative on the one hand assumed elite stability, on the other hand it assumed the opposite with respect to patrons of the melodrama. Such assumptions also concerned the social background of subscribers. This background was analysed from the point of view of social mobility. The implied hypotheses of the dominant narrative were that in the first half of the $19^{\text {th }}$ century, opera patrons had a more stable ('elite') background than melodrama patrons, who, perhaps showed signs of upward mobility. Since Dutch social historians generally assume that upward social mobility accelerated after 1870 , it is of interest to analyse the later cohorts (opera, 1860-1882; drama, 1890-1895 and 1902-1912) with respect to social mobility. We collected data on the social backgrounds of the subscribers, provided they were born in the Rotterdam region. It turned out that about half of the subscribers generation was born in the region, and that per parental generation this half-life persisted. Because it regularly happened that fathers or grandfather also subscribed in one of the cohorts, we could generate genealogical data for five generations, so that the prosopography of theatre goers stretched from about 1700 to 1914 (and for some till 1959). It must be stressed, however, that the fourth and fifth generation data are not of the same sort as the data for the second and third generation. We systematically searched for these latter data, whereas the fourth and fifth generations were just generated because a subscriber's father or grandfather had also subscribed. It made not much sense to study the $18^{\text {th }}$-century cohorts in that way, because researching theatre-going in a city without a theatre is fruitless: only the patrician families were researched. We included, however, the father and grandfather generations of the early- $19^{\text {th }}$ century cohorts, because of the assumption of social decline in the melodrama cohort.

Tables $7 \mathrm{a}-7 \mathrm{~d}$ (appendix 3) sum up the results. ${ }^{50}$ From Table $7 \mathrm{a}$ it appears that the social background of the fathers and grandfathers of the subscribers for opera and drama in the first half of the $19^{\text {th }}$ century was not wildly different. There is a steady difference in the percentages of 'trade' and 'middle class' occupations. Noteworthy, however, is the absence of the expected massive lower middle and working-class parentage of melodrama patrons. The outcomes for the first half of the $19^{\text {th }}$ century tend to be reproduced over the whole period.

${ }^{50}$ ) The data for wealth, of course, had to use different sorts of taxes. For the opera, 1860-82 the wealth class of generation 1 was based on Nett Income (901 of 1150, valid percentage 78.3); that of generation 2 on rateable value ( 389 of 555, valid percentage 70.1); that of generation 3 on rateable value (173 of 299, valid percentage 57.9). The generations 4 and 5 have not been included, but on the basis of rateable value the outcome is 26 of $103(35.0 \%)$ and 4 of $40(10 \%)$ respectively. For drama, 1902-12 generation 1 was based in Income (1247 of 1476, valid percentage 84.5); generation 2 was based on Nett Income (465 of 797, valid percentage 84.5); generation 3 on rateable value (246 of 472, valid percentage 52.1). Generations 4 and 5, rateable value, give 48 of 140 (34.3\%) and 10 of 56 $(17.9 \%)$ respectively. 
Particularly in grandfather generation in the later $19^{\text {th }}$-century cohorts (Tivoli theatre!), there is an increase in working and middle class background, but it is small when compared to the category 'trade.' There is an interesting difference between the categories 'trade' and 'professionals' in the subscriber generation Tivoli (1890-1895) and Van Eysden (1902-1912). The Tivoli Theatre intended to become an intimate surrounding for an arty elite, and its seats in the tiers were relatively expensive. Apparently this helped to shut out subscribers of the occupation category 'professionals.' Curious, thus, that relatively more subscribers for this arty surrounding had a working-class grandfather. Perhaps, upward mobility had to show itself and preferred to do so in an self-styled arty new venue with no lineage.

The distribution of occupations among the first three generations is significant per cohort and therefore not due to chance. ${ }^{51}$ Tables $7 \mathrm{~b}$ and $7 \mathrm{c}$ indicate that also with respect to wealth, no sharp differentiations occur between the later $19^{\text {th }}$-century cohorts. That is to say, for the opera (1860-1882), the categories 'trade' and 'academics' stay relatively wealthy, while the other occupation categories have their basis in the third wealth class. For drama (1902-1912), the same counts, except that 'middle class' occupations and 'professionals' in the father generation tended to be in the second wealth class instead of the third. Both for drama (1902-1912) and opera (1860-1882) the distribution of wealth class over the first three generations are not due to chance. ${ }^{52}$

The melodrama cohort (1824-1830, table 7d) which particularly interests us here, yielded less wealth data since the earliest list of rateable values stems from 1803. Data from the Marriage and Burial Tax (MTB) gave a better picture for the grandfather generation, of which 38 per cent was taxed in the highest class (a fortune of at least fl. 12,000.-). The tendency is that fathers in 'trade' were relatively more wealthy than in other occupations, but few fell in the lowest wealth class of the rateable value. The Marriage and Burial tax points roughly to the same. A tax sum of fl. 3.- or fl. 6.- suggests middle class wealth (fl. 1500.- to fl. 3000.-).

According to the traditional narrative, we should expect that the melodrama ancestors scored badly in social and cultural variables as well, but they did not. Of 178 identified fathers, 40 held political and social functions (22 per cent), and of the 43 identified grandfathers 10 did ( 23 per cent). Among the functions held by the father generation were a burgomaster, an alderman, and nine councillors. Moreover we found two consuls and a member of the Provincial Estates. The grandfather generation included a burgomaster, two

\footnotetext{
51) The data are derived from Table 7a (number of occupations per job category). Opera 1860-82: chi-square $=45.5 ; \mathrm{df}=8 ; \mathrm{p}<0.00 ;$ drama, 1902-12: chi-square $=255.1 ; \mathrm{df}=10 ; \mathrm{p}<0.00$. Tivoli 1890-95: chi-square $=98.5 ; \mathrm{df}$ $=10 ; \mathrm{p}<0.00$. For opera we had to leave out the category 'working class.'

52 ) The data are derived from tables $7 \mathrm{~b}$ and $7 \mathrm{c}$ (sums of wealth classes). Drama, 1902-12: Chi-square $=176.8$; $\mathrm{df}=8 ; \mathrm{p}<0.00$. Opera, 1860-82: Chi-square $=114.8 ; \mathrm{df}=8 ; \mathrm{p}<0.00$. Due to the small sums in class 1 , the results for the opera cohort are just valid $(20 \%$ of the expected values were $<5)$. For this cohort we had to leave out the working class (empty cells). We did not produce a table for drama, 1890-95 for sake of space.
} 
members of the Provincial Estates and six councillors. For 31 of the 178 fathers we found data on sociability (17 per cent). These concerned the elite members of the cohort. They shared 59 memberships. It must be recalled that there are few data for $18^{\text {th }}$-century sociability. In the grandfather generation, therefore, the number was, as we expected worse: ten persons (13 per cent) shared 17 memberships.

The score fo the melodrama cohort is not extremely different from the data of the later cohorts. Comparing it to opera (1860-1882), and drama (1902-1912), which cohorts benefited from the generally better archive position of the $19^{\text {th }}$ century, it turned out that the fifth wealth classes fathers took by far the most functions. ${ }^{53}$ Remarkably, the number of functions taken by drama-fathers was (slightly) higher than with the subscribers themselves. Political functions dominated in the background of these subscribers' parentage, so that those in power generated a more theatre-minded offspring. ${ }^{54}$ Of the drama-fathers 67 had ties to liberal election clubs and five with christen-democrats (of 797 persons). The grandfather generation of the dramasubscribers counted eleven Patriots and two Orangists (of 472 persons), nine liberals, one conservative and a socialist. ${ }^{55}$ Of the opera-fathers, 24 were associated with liberal election clubs and four with conservative clubs; of the opera grandfathers, ten had been Orangists and 34 Patriots. These are small figures with respect to the cohorts, but they are of interest, since little political allegiance could be detected and they mesh with the findings for political allegiance in the subscribers' cohorts themselves.

The outcome of these analyses of the social backgrounds of the subscribers does in no way support the implied assumptions of the traditional narrative with respect to the social background of melodrama subscribers. They constitute an overall stability in the social composition of subscribers in time. Many of the late $18^{\text {th }}$-century merchant families, who did not belong to the regent caste still subscribed for theatre tickets at least until the Great War. The drama and opera cohorts show some differences which allow the conclusion that opera patrons had a socially 'better' background, but the differences are relatively small.

\section{Discussion}

The survey of the social variables relevant for testing the traditional historiography on the composition of the audience in the long $19^{\text {th }}$ century concludes to the untenableness of the traditional historiography. Subscribers formed a considerable part of the audience and were

\footnotetext{
53 ) Opera-fathers: $49 \%$; drama-fathers: $62 \%$, drama-grandfathers: $52 \%$, only with opera-grandfathers the fourth class dominates with $61 \%$ over the fifth class.

${ }^{54}$ ) Opera-subscribers: $9 \%$, opera-fathers: $13 \%$, opera-grandfathers: $25 \%$; drama-subscribers: $10 \%$, dramafathers: $8 \%$; drama-grandfathers: $18 \%$ ).

${ }^{55}$ ) Only in the great-grandfather generation we reach the political struggles of the old regime: 25 greatgrandfathers were Patriots, against 3 Orangists (140 persons).
} 
generally wealthy, powerful, sociable, well educated, and politically engaged. They were overrepresented in the religious denominations, which were tolerant to profane culture and rather old. Other cultural variables also show continuity rather than change over the period. Rank differences in social background do not automatically imply a non-bourgeois social background of the rank as a whole. As regards the genealogical background of subscribers, theatre-going had its basis in wealthy traders under the level of the aristocrat regent families, and spread into middle class professions both in service ('professionals') and the economic activity ('middle class'). The theatre, therefore, was essentially and throughout the whole period of time we studied a form of amusement, for a solid citizenship. Theatre-going ran in the family. The effects of upward social mobility per generation in at least the city-born subscribers was relatively small, but tended to upward mobility. This is more spectacularly noticeable on the individual career level. This often meant that the rich got richer.

Our analyses pointed to tenacious elements in the social background of theatre-goers. They were often wealthy, occupied in trade, mighty, and took an interested in other cultural organizations. The beginnings of stimulating profane theatre culture in Rotterdam were located in the Estate-minded regents, who oppose the orthodoxy then related to Orangists. After 1672 some of them became dissenters (Arminians), others became the enlightened regents, who had awkward relations with the democratic Patriot burghers in the later $18^{\text {th }}$ century, often also dissenters and the founding fathers the first standing theatre. As liberals and increasingly nondenominational - they enter the twentieth century. It looks that the theatre is a prison of longue durée. ${ }^{56}$

${ }^{56}$ ) Vovelle, "Histoire des Mentalités, histoire des résistances, ou les prisons de longue durée," (1980). 


\title{
Appendix 1. The subscription lists
}

\author{
$18^{\text {th }}$ Century Lists
}

Dutch Drama, seasons 1773-74 to $1777-78,44$ subscribers season tickets and prepaid tickets

Dutch Drama, season 1778-79, 113 subscribers for season tickets to rescue the theatre

Dutch Drama, season 1792-93, 25 subscribers for season tickets

French Opera, seasons 1789-90 to 1791-92, 120 subscribers for season tickets

Concert Series, 1789-90 to 1791-92, 56 subscribers for season tickets.

\section{$19^{\text {th }}$ Century Lists}

Dutch Drama, season 1824-25 to 1829-30, season tickets, 253 subscribers

Dutch Drama, season 1867-68, coupons, 115 subscribers

Dutch Drama, season 1890-91 to 1894-95, coupons, 582 subscribers (Tivoli Theatre)

Dutch Drama, seasons 1879-80 to 1898-99 (incomplete!), coupons 363 subscribers

French Opera, seasons 1817-18 to 1819-20 (boxes only), season tickets, 37 subscribers

French Opera, seasons 1836-37 to 1838-39, season tickets, 208 subscribers

French Opera, season 1843-44, season tickets, 81 subscribers

German Opera, season 1860-61 to 1861-62, 147 shareholders with box diploma

German Opera, season 1865-66 to 1866-67, 560 discount subscribers to guarantee fund

German Opera, season 1867-68, coupons, 442 subscribers

German Opera, season 1879-80, coupons, 469 subscribers

German Opera, season 1881-82, season tickets, 130 subscribers

\section{Twentieth Century Lists}

Dutch Drama, seasons 1902-03 to 1911-12, coupons, 1476 subscribers

German Opera, Maifestspiele 1909 and 1911, 677 subscribers from Rotterdam

Italian Opera, season 1933-34, 248 subscribers in Rotterdam

Dutch Drama, season 1959-1960, 124 subscribers in Rotterdam (and Schiedam - not identified)

In view of the overlap of subscribers, and also in order to prevent too many analyses on small cohorts of subscribers, we also formed combinations of cohorts, to wit:

Dutch-spoken Drama, 1773-1792: 157 persons

French Opera, 1817-1844: 276 persons

German Opera, 1860-1882: 1150 persons 


\section{Appendix 2. An assessment of the data}

Since the aggregated cohorts contain more than one season, the highest rank occupied by a theatre-goer has been taken for our analyses. In some cases persons switched rank. This could be related to upward social mobility, but also to ranks no longer being available (as was the case with fifth-rank coupons by Van Eysden, 1902-1912). In some few cases, however, the very rich bought coupons for a welter of ranks. To double-calculate those for all these ranks would very likely severely distort the facts of theatre-going, since in many of these cases rich merchants and harbour barons bought tickets to give to their employees or their domestic servants (a chauffeur, the lady-companion to the mistress, or maids to go out on Sunday). Persons, however, were in most cases loyal to one rank or even to a seat.

In many cases persons bought more than one season ticket. Most likely they were accompanied by their wives. These have not been separately included, except when the ticket is emphatically put on their names. Particularly for the early period and for Dutch-spoken drama we cannot be sure that a second season ticket was used for a wife, since there were social impediments on taking decent ladies to the pit of the theatre (and most of the tickets were for the pit). The question of women subscribers is dealt with in the main text.

The cohorts vary considerably in size, subscription for only season tickets in the $18^{\text {th }}$ and early $19^{\text {th }}$ centuries limping behind the more generous subscription after 1860. The cause is no doubt the introduction of coupons. The many cohorts made it unhelpful to draw representative samples, since these should include most of the subscribers. So, we gathered information about all subscribers. All cohorts had a small amount of subscribers who could not be identified.

In relative numbers, the subscribers before 1792 form only a small part of the audience. The season ticket holders 1824-30 are about 50 per cent of the average pit occupation rate per season. Since boxes and amphitheatre were hardly occupied when Dutch drama was staged, this is not a bad score. It is, of course, likely that buyers of single tickets may have had less income than the season ticket holders, but in the $19^{\text {th }}$-century (Dutch) context it is highly unlikely that the rich and mighty would mix with the lower classes. Hence, the reasonable expectation on the basis of the social composition of the season-ticket holders is, that the pit had a solid citizen profile. The 1867 drama list is less likely to be representative. The figures for the Tivoli theatre, 1890-1895 are more complex. This theatre, opened in 1890 with the intention to serve an arty elite with new drama (naturalism) in an intimate environment, saw its patronage decline from the first season onwards. Coupon sales, however, remained relatively stable at 10 per cent average for the first and second rank and about 5 for the pit, so that its relative weight became larger. The use of coupons also depended also on rank and weekday. Using mean ticket sales per weekday over all five seasons, on a Sunday, coupons-tickets on the first ranks formed about some 25 per cent of the audience, whereas on Saturday it would be some 33 per cent - Monday and Thursday somewhere in between these figures ( 29 to 31 per cent). For the second rank these percentages are 20,19, 19, and 20 respectively, and for the third rank (the pit) it was about 7 per cent on all occasions. In the Grand Theatre, Van Eysden gave Sunday plays and performed on Tuesday and Friday. The first rank on Sunday had an average season ticket and coupon participation of some 25 per cent, which increased for Tuesdays to some 73 per cent, and for Friday to some 65 per cent. For the second rank these figures are 28, 50, and 45 per cent respectively, whereas for the pit (fourth rank) they dropped to some 16, respectively 26 and 22 per cent. The figures for the third and particularly fifth rank (side balcony and side boxes) were even less. The third rank, moreover, was not always available at its reduced price. It was normally part of the first rank (and shunned, then, due to failing acoustics and bad sight). These figures are also based on the average ticket sales for the normal performance days over the whole period of Van Eysden's management (1900-1916). For the first and second ranks in both theatres, the scores are particularly good, for the pit it is less well, but with Van Eysden still not bad. For the lower ranks the score is too low to give a general estimate of the social composition. The side boxes, amphitheatres, and galleries were normally very poorly occupied, except in case of Sunday plays with reduced prices, cheap 'popular' Monday plays and then only with respect to a limited repertoire. The fact that spectators for these ranks had th enter through the back door, and were not allowed in the main foyers heeded bad blood.

In the later $18^{\text {th }}$ and the first half of the $19^{\text {th }}$ century boxes were en vogue for the opera. We have most of the box audience for the Rotterdam French Opera 1789-92 and the Royal French Opera of The Hague, 1817-20. For these latter years no subscriptions for the pit have been preserved, but for the pit of the 1789-92 opera seasons the number of subscribers was considerable (some 35 per cent on an average basis). The best figures come from the 
French Royal Opera seasons 1836-38, were we have about all the pit, amphitheatre and box audience. The Amsterdam French Opera, 1843-44 had 200 subscribers for the pit (over 50 per cent of the seats). Here no subscriptions were made for the boxes, although the ticket sales accounts prove that these were sold, too, but not on a season-ticket basis. The 1150 subscribers for the German opera must have formed, on the basis of their number and the occupation rates, a considerable part of the audience of the stalls, balcony, boxes, and pit. On the whole, we think these are sufficient data to work with.

Data on address, occupation, religion, and age were found in the address books and the population registers. Occupations led to an immensely fragmented list, which we ordered in job categories. For presentation in this relatively limited space, we use six even more concise macro-categories: trade, middle class, academics, professionals, working class, and none (see for the specification of the job categories the legend of table 1a). Wealth classes were based on several city taxes. These wealth classes all have the following characteristics: class 1 is the lowest category, based on an acknowledged small income; class 2 forms a transition segment to middle class incomes; class 3, hence, covers solid middle class incomes. Class 4 represents a transition segment to the very rich, who are in class 5. From 1803 to about 1850 the rateable value was the basis for most local taxes and for the national wealth tax; after 1856 a direct poll tax, roughly based on expenditure, was calculated with diverse, complicated formulas, until in 1893 a formal income tax was instituted. This lasted till 1922, when local direct taxes were abolished. The changes in the tax system make it impossible to exactly compare the outcomes of wealth for the several cohorts in time, although they also are not widely apart. ${ }^{57}$ The outcomes for rateable value and the diverse sorts of income tax differ, due to the limit on the first (hence, there are relatively less class 5 rateable values than class 5 incomes) ${ }^{58}$ In the analyses we have taken account of inflation.

Sources for functions were the official lists (the so-called Heerenboekjes), the address books, published genealogies in the series Nederlands Patriciaat [Dutch Patriciate], and the first and fifth volumes of series Bronnen voor de geschiedenis van Rotterdam [Sources of Rotterdam History], compiled at the Municipal Archive: De Regeering van Rotterdam, 1328-1892, ed. J.H.W. Unger (Rotterdam, 1892), and De Vroedschap van Rotterdam, 1572-1795, ed. E.A. Engelbrecht (Rotterdam, 1973).

For an estimation of sociability we researched memberships of a welter of societies and clubs. These were divided into the main categories as given in table 5a (appendix 3). The data is derived from two sources: membership lists and address book data. Address books only give the committee members of a club. Membership lists were not always available for the whole period. It is a pity, for instance, that the lists for the important Society for Public Welfare (abbreviated as the Nut, founded in 1784) are not available for the period ca. 1810-1880, although many of its active members were listed in the address books; those for the Society for the Advancement of Music [Toonkunst]

${ }^{57}$ ) See for the attempts to relate the diverse forms of direct city taxes to income, Boudien de Vries, Electoraat en elite. Sociale structuurmobiliteit in Amsterdam, 1850-1895 (Amsterdam, 1986), and Henk Visscher's critique “"Een goede waterweg en elastieke financien.' Een speurtocht naar de optimale belastingreeks voor het welvaartsonderzoek in de tweede helft van de negentiende eeuw," in: Rotterdams Jaarboekje (Rotterdam, 1999), pp. 312-336.

${ }^{58)}$ Wealth categories have been based on different sorts of taxes. Dutch-spoken Drama: Dutch Drama, 177392 , is based on rateable values (tax registers 1803, 1826, 1833), or on the on the Marriage and Burial tax (abolished in 1810). This tax had four classes based on wealth position (fl. 1000.-, 3000.-, 6000.- and 12,000.- respectively). Wealth classes of Dutch Drama, 1824-1830 were based on rateable values (tax-registers 1803, 1822, 1826, 1833, and registers of real property, 1832, 1848). Wealth categories of Dutch Drama, 1867 were based on the city poll tax (assessment lists 1856, 1859, 1865, 1869, 1880). Both Tivoli, 1890-95 and Van Eysden, 1902-1912 were based on the city income tax (assessment lists, 1893, 1902, 1905, 1908, 1912). French Opera 1789-92 is based on rateable values (tax registers 1803, 1826, 1833), whereas also the Marriage and Burial tax was relevant. Wealth categories of the French Opera, 1817-43 are based on rateable values (tax registers 1803, 1826, 1833 and registers of real property, 1832,1848 ). Wealth categories for the German Opera are based on the city poll tax (assessment lists 1856, 1859, $1865,1869,1880$ ), and those for the Maifestspiele were based on the city income tax (assessment lists 1893, 1902, $1905,1908,1912)$. 
are only available after about 1900. For Harmony [Harmonie], one of the most important cultural clubs in the $19^{\text {th }}$ century, the membership lists for the early years are missing. ${ }^{59}$ There is also a bias for the clubs frequented by the well-to-do, since they existed longer and were more careful archivists. ${ }^{60}$ The 1940 bombing destroyed many archival materials which were kept at home.

For $18^{\text {th }}$-century political allegiance, we benefited much from Eric Palmen, De Kooplieden van Rotterdam [Rotterdam Merchants], internal report MAR (1994). 19 $9^{\text {th }}$-century data came from the New Rotterdam Journal and the archive of the election club Burgerpligt. We consulted the school archives of the Burgher-schools (five and three year course), and the Latin school (later gymnasium). Data on education before 1860 were restricted to higher education. Medical doctors, lawyers, and judges had to finish the university; whereas surgeons had to finish the Illustrious School of surgery.

Merchant class children often took one of four courses (or mixed them): they got practical training in the business companies of their class, they went to private French schools, or to boarding schools. Private teaching at home was the most expensive option. Neither of these road maps to knowledge has left sufficient archival documents. Hence, our knowledge of education before 1865 is sparse and restricted to gymnasium, university, and the illustrious school. In 1863 a wholesale reorganisation of the system took place, the government taking far more responsibility. The most pregnant new institutions were the burgher-schools with a five or three years course. The gymnasium was reformed and modernized. Soon there were also burgher-schools for girls (Rotterdam, 1870). The archives for these schools have been preserved. Still, quite some children of the rich - particularly boys - did not go to the burgherschools, because parents objected against a five-year training. Boarding schools remained en vogue in the merchant elite. The success story of the burgher-schools started only at the beginning of the twentieth century. There are also data for technical education, but these are complicated and incomplete, while in fact the occupation of a subscriber already signals what sort of training had likely been followed. It is, however, a pity that so little archive materials are left of the comprehensive primary teaching schools ( $U L O$ and $M U L O$ ), in which many of the middle classes were (supposed to have been) trained. In 1889 some 1500 boys and 1450 girls attended those schools. They, too were a success story until their abolition, in 1968.

${ }^{59}$ ) There is, though, a brochure from 1840, signed by some fifty members, while also all committee members are known.

\footnotetext{
$\left.{ }^{60}\right)$ These clubs were also more prone to donated their archives to the municipal archive, which was preserved in 1940 .
} 


\section{Appendix 3, Basic Tables}

Table 1a. Opera, Wealth Class by Job Category

\begin{tabular}{|c|c|c|c|c|c|c|c|}
\hline $\begin{array}{l}\text { Wealth class } \rightarrow \\
\text { Jobcat } \downarrow\end{array}$ & 1 & 2 & 3 & 4 & 5 & sum & $\%$ \\
\hline \multicolumn{8}{|c|}{ French Opera. 1789-1792. Rateable Values $\mathrm{N}=120$. Valid Total $83(69$} \\
\hline trade & - & - & 11 & 15 & 15 & 41 & 80.4 \\
\hline middle class & - & - & - & - & - & - & - \\
\hline academics & - & - & 1 & 1 & 1 & 3 & 5.9 \\
\hline professionals & - & - & 3 & 2 & - & 5 & 9.8 \\
\hline none & - & - & 1 & 1 & - & 2 & 3.9 \\
\hline sum & - & - & 16 & 19 & 16 & 51 & 100 \\
\hline percentage & - & - & 31.3 & $\mathbf{3 7 . 3}$ & 31.3 & 100 & \\
\hline
\end{tabular}

French Opera. 1817-1844. Rateable Values $\mathrm{N}=276$. Valid Total $236(85.5 \%)$

trad

academic

professionals

none

$\begin{array}{lllll}46 & 57 & 49 & 152 & 64.4 \\ 7 & 4 & 2 & 13 & 5.5 \\ 7 & 15 & 13 & 35 & 14.8 \\ 16 & 9 & 3 & 28 & 11.9 \\ 2 & 2 & 4 & 8 & 3.9\end{array}$

sum

percentage

$\begin{array}{lllll}78 & 87 & 71 & 236 & 100\end{array}$

French Opera. 1852-59, approximately. Poll Tax N = 134. Valid Total: $111(82.8 \%)$

\begin{tabular}{llllllll} 
trade & - & 11 & 3 & 16 & 48 & 78 & 70.3 \\
middle class & - & 2 & 5 & 2 & - & 9 & 8.1 \\
academics & - & - & 1 & 2 & 5 & 8 & 7.2 \\
professionals & - & - & 2 & 3 & 1 & 6 & 5.4 \\
none & - & 1 & 1 & 4 & 4 & 10 & 9.0 \\
& & & & & & & \\
\hline sum & - & 14 & 12 & 27 & 58 & 111 & 100 \\
percentage & - & 12.6 & 10.8 & 24.3 & 52.3 & 100 &
\end{tabular}

$\begin{array}{lllllll}1 & 2 & 3 & 4 & 5 & \text { sum } & \%\end{array}$

Drama, 1773-1792. Rateable Values $\mathrm{N}=157$. Valid Total $49(31.2 \%)$

\begin{tabular}{lllllll}
- & - & 15 & 13 & 9 & 37 & 75.5 \\
- & - & 2 & - & - & 2 & 4.1 \\
- & - & - & 1 & 1 & 2 & 4.1 \\
- & - & 3 & 2 & - & 5 & 10.2 \\
- & - & 1 & 1 & 1 & 3 & 6.1 \\
\hline- & - & 21 & 17 & 11 & 49 & \\
\hline & & 42.9 & 34.9 & 22.4 & 100 &
\end{tabular}

Drama, 1824-1830. Rateable Values $\mathrm{N}=253$. Valid Total $205(81.0 \%)$

\begin{tabular}{lllllll}
- & 1 & 60 & 43 & 23 & 127 & 62.0 \\
- & - & 12 & 13 & 7 & 32 & 15.6 \\
- & - & 3 & 6 & 2 & 11 & 5.4 \\
1 & - & 26 & 1 & - & 28 & 13.7 \\
- & 1 & 2 & 4 & - & 7 & 3.4 \\
& & & & & & \\
\hline 1 & 2 & 103 & 67 & 32 & 205 & 100 \\
0.5 & 1.0 & 50.2 & 32.7 & 15.6 & 100 &
\end{tabular}

Drama, 1867-1868, Poll Tax $\mathrm{N}=115$. Valid Total $99(86.1 \%)$

\begin{tabular}{lllllll}
- & 2 & 11 & 12 & 30 & 55 & 55.6 \\
- & 4 & 13 & 2 & 3 & 22 & 22.2 \\
- & - & 2 & 1 & 6 & 9 & 9.1 \\
- & 3 & 3 & 2 & 4 & 12 & 12.1 \\
- & - & - & 1 & - & 1 & 1.0 \\
& & & & & & \\
\hline- & 9 & 29 & 18 & 43 & 99 & 100 \\
- & 9.1 & 29.3 & 18.2 & 43.4 & 100 &
\end{tabular}


continuation of table 1 a

$\begin{array}{llllllll}\text { Wealth class } \rightarrow & 1 & 2 & 3 & 4 & 5 & \text { sum } & \% \\ \text { Jobcat } \downarrow & & & & & & & \end{array}$

German Opera, 1860-1882. Poll Tax $\mathrm{N}=1186$ Valid Total: 913 (77.0\%)

\begin{tabular}{llllllll} 
trade & $\mathbf{1}$ & $\mathbf{4 6}$ & $\mathbf{9 8}$ & $\mathbf{1 3 0}$ & $\mathbf{2 4 5}$ & $\mathbf{5 2 0}$ & $\mathbf{5 6 . 7}$ \\
middle class & $\mathbf{1}$ & $\mathbf{2 7}$ & $\mathbf{7 0}$ & $\mathbf{4 3}$ & $\mathbf{1 5}$ & $\mathbf{1 5 6}$ & $\mathbf{1 7 . 3}$ \\
academics & $\mathbf{1}$ & $\mathbf{1 1}$ & $\mathbf{1 5}$ & $\mathbf{2 5}$ & $\mathbf{3 6}$ & $\mathbf{8 8}$ & $\mathbf{9 . 6}$ \\
professionals & $\mathbf{1}$ & $\mathbf{3 7}$ & $\mathbf{3 9}$ & $\mathbf{1 8}$ & $\mathbf{8}$ & $\mathbf{1 0 3}$ & $\mathbf{1 1 . 6}$ \\
working class & - & 1 & - & - & - & $\mathbf{1}$ & - \\
none & 1 & $\mathbf{5}$ & 7 & 11 & $\mathbf{2 1}$ & $\mathbf{4 5}$ & $\mathbf{4 . 9}$ \\
\hline sum & & & & & & & \\
percentage & $\mathbf{5}$ & $\mathbf{1 2 7}$ & $\mathbf{2 2 9}$ & $\mathbf{2 2 7}$ & $\mathbf{3 2 5}$ & $\mathbf{9 1 3}$ & $\mathbf{1 0 0}$
\end{tabular}

Tivoli, 1890-1895, Income Tax $\mathrm{N}=582$. Valid Total $418(71.8 \%)$

Maifestspiele. 1909. 1911. Income Tax N =677. Valid Total: 540 (79.8\%).

\begin{tabular}{llllllll} 
trade & $\mathbf{2}$ & $\mathbf{9}$ & $\mathbf{3 7}$ & $\mathbf{2 9}$ & $\mathbf{1 0 6}$ & $\mathbf{1 8 3}$ & $\mathbf{3 3 . 9}$ \\
middle class & $\mathbf{1 4}$ & $\mathbf{1 6}$ & $\mathbf{2 5}$ & $\mathbf{9}$ & $\mathbf{1 1}$ & $\mathbf{7 5}$ & $\mathbf{1 3 . 9}$ \\
academics & - & $\mathbf{3}$ & 7 & $\mathbf{1 0}$ & $\mathbf{1 4}$ & $\mathbf{3 4}$ & $\mathbf{6 . 3}$ \\
professionals & $\mathbf{5 6}$ & $\mathbf{7 3}$ & $\mathbf{4 8}$ & $\mathbf{1 1}$ & $\mathbf{1 3}$ & $\mathbf{2 0 1}$ & $\mathbf{3 7 . 2}$ \\
working class & 7 & - & 2 & - & - & 9 & 1.7 \\
none & 4 & 6 & 11 & $\mathbf{8}$ & $\mathbf{9}$ & $\mathbf{3 8}$ & $\mathbf{7 . 0}$ \\
& & & & & & & \\
\hline sum & $\mathbf{8 3}$ & $\mathbf{1 0 7}$ & $\mathbf{1 3 0}$ & $\mathbf{6 7}$ & $\mathbf{1 5 3}$ & $\mathbf{5 4 0}$ & $\mathbf{1 0 0}$ \\
percentage & 15.3 & 19.8 & 24.1 & 12.4 & $\mathbf{2 8 . 3}$ & $\mathbf{1 0 0}$ &
\end{tabular}

\begin{tabular}{lllllll}
6 & 24 & 55 & 39 & 103 & 227 & 54.3 \\
5 & 16 & 18 & 8 & 14 & 61 & 14.6 \\
1 & 10 & 13 & 8 & 14 & 46 & 11.0 \\
6 & 13 & 19 & 7 & 7 & 52 & 12.4 \\
2 & - & - & - & - & 2 & 0.5 \\
4 & 6 & 12 & 4 & 4 & 30 & 7.1 \\
& & & & & & \\
\hline 24 & 69 & 117 & 66 & 142 & 418 & $100 \%$ \\
5.7 & 16.5 & 28.0 & 15.8 & 34.0 & 100 &
\end{tabular}

Main job-categories contain the following sub-categories: Trade: bankers, stock traders, insurers, merchants, transit-traders, major industrials, trade agents, and the in-between categories of trade-and-finance, trade-and-industry, trade-and-transport. Middle Class: wholesalers, retailers, artisans, building-trade, book-trade, hotel and catering industry. Academics: medical professions, notaries, attorneys and advocates. Professionals: employees, civil servants, clergymen, technicians, officers in army and navy, education, art and journalism. Working Class: skilled and unskilled industrial and artisan labourers, domestic servants, seamstresses. None; unknown, not relevant (institutions), private persons. 
Table 1b. Rank, job-category, and wealth

Opera, 1860-1882, Poll Tax

Drama, 1902-1912, Income Tax

\begin{tabular}{|c|c|c|c|c|c|c|c|c|c|c|c|c|}
\hline $\begin{array}{l}\text { Wealth class } \rightarrow \\
\text { Jobcat } \downarrow\end{array}$ & 1 & 2 & 3 & 4 & 5 & sum & 1 & 2 & 3 & 4 & 5 & sum \\
\hline \multicolumn{13}{|l|}{ trade } \\
\hline Rank 1 & - & 1 & 3 & 23 & 103 & 130 & 2 & 14 & 67 & 70 & 268 & 421 \\
\hline Rank 2 & - & 7 & 21 & 26 & 44 & 99 & 2 & 13 & 39 & 13 & 13 & 80 \\
\hline Rank 3 & - & 23 & 46 & 40 & 48 & 157 & - & 3 & 7 & 3 & 1 & 14 \\
\hline Rank 4 & & & & & & & 5 & 14 & 15 & 1 & - & 35 \\
\hline Rank 5 & & & & & & & - & - & 2 & - & - & 2 \\
\hline \multicolumn{13}{|l|}{ middle class } \\
\hline Rank 1 & - & 1 & 1 & 1 & 1 & 4 & 2 & 3 & 14 & 16 & 28 & 63 \\
\hline Rank 2 & - & 1 & 7 & 4 & 4 & 16 & 2 & 20 & 37 & 10 & 7 & 76 \\
\hline Rank 3 & - & 19 & 38 & 15 & 6 & 78 & 3 & 6 & 14 & 8 & 1 & 32 \\
\hline Rank 4 & & & & & & & 9 & 16 & 16 & 3 & - & 44 \\
\hline Rank 5 & & & & & & & 2 & 3 & 1 & - & - & 6 \\
\hline \multicolumn{13}{|l|}{ academics } \\
\hline Rank 1 & - & - & 1 & 5 & 16 & 22 & 1 & 2 & 10 & 17 & 33 & 63 \\
\hline Rank 2 & - & - & 4 & 6 & 6 & 17 & 1 & 2 & 4 & 1 & - & 8 \\
\hline Rank 3 & 1 & 5 & 8 & 7 & 5 & 26 & - & - & - & 1 & - & 1 \\
\hline Rank 4 & & & & & & & - & 1 & - & - & - & 1 \\
\hline Rank 5 & & & & & & & - & - & - & - & - & - \\
\hline \multicolumn{13}{|l|}{ professionals } \\
\hline Rank 1 & - & - & - & 2 & 1 & 3 & 4 & 12 & 31 & 25 & 19 & 91 \\
\hline Rank 2 & - & - & 1 & 2 & 4 & 7 & 7 & 19 & 45 & 7 & - & 78 \\
\hline Rank 3 & 1 & 17 & 24 & 7 & - & 49 & 5 & 16 & 8 & 1 & - & 30 \\
\hline Rank 4 & & & & & & & 21 & 40 & 7 & - & 1 & 69 \\
\hline Rank 5 & & & & & & & 2 & 4 & 1 & - & - & 7 \\
\hline \multicolumn{13}{|l|}{ working class } \\
\hline Rank 1 & & & & & & & - & - & - & - & - & - \\
\hline Rank 2 & & & & & & & 1 & - & 3 & - & - & 4 \\
\hline Rank 3 & & & & & & & - & - & - & - & - & - \\
\hline Rank 4 & & & & & & & 2 & - & 1 & - & - & 3 \\
\hline Rank 5 & & & & & & & 1 & - & - & - & - & 1 \\
\hline \multicolumn{13}{|l|}{ none } \\
\hline Rank 1 & - & - & - & 2 & 10 & 12 & 4 & 8 & 17 & 22 & 28 & 79 \\
\hline Rank 2 & - & 2 & - & 3 & 1 & 6 & 2 & 6 & 8 & - & - & 16 \\
\hline Rank 3 & - & 2 & 2 & 3 & 1 & 8 & 2 & 5 & 2 & - & - & 9 \\
\hline Rank 4 & & & & & & & 4 & 6 & - & - & - & 10 \\
\hline Rank 5 & & & & & & & 1 & 1 & 2 & - & - & 4 \\
\hline
\end{tabular}


Table 3a: Religious denominations [source for city data: Municipal Reports, and A.Th.C. Kersbergen, Mentink \& Van der Woude (ca. 1820)]

\begin{tabular}{|c|c|c|c|c|c|c|c|c|c|c|}
\hline $\begin{array}{l}\text { cohort \& } \\
\text { perc. inhabitants } \rightarrow \\
\text { religions } \downarrow\end{array}$ & $\begin{array}{l}\text { drama } \\
1773-92 \\
N=157\end{array}$ & $\begin{array}{l}\text { opera } \\
1789-92 \\
N=120\end{array}$ & $\begin{array}{l}\text { city, } \% \\
\text { ca. } 1820\end{array}$ & $\begin{array}{l}\text { drama } \\
1824-30 \\
N=253\end{array}$ & $\begin{array}{l}\text { opera } \\
1817-44 \\
N=276\end{array}$ & $\begin{array}{l}\text { opera' } \\
1850-59 \\
N=134\end{array}$ & $\begin{array}{l}\text { city \% } \\
1865\end{array}$ & $\begin{array}{l}\text { drama } \\
1867-68 \\
N=115\end{array}$ & $\begin{array}{l}\text { opera } \\
1860-82 \\
N=1150\end{array}$ & $\begin{array}{l}\text { city } \% \\
1880\end{array}$ \\
\hline Dutch Reformed & $48(30.6)$ & $26(21.7)$ & $61.0 \%$ & $126(49.8)$ & $107(38.8)$ & $52(38.8)$ & $57.4 \%$ & $58(50.4)$ & $529(46.0)$ & $57.2 \%$ \\
\hline English Church & $7(4.5)$ & $10(8.3)$ & & $4(1.7)$ & $5(1.8)$ & $3(2,2)$ & $0.2 \%$ & $2(1.7)$ & $10(0.9)$ & $0.1 \%$ \\
\hline Scottish Church & $1(0.6)$ & $2(1.7)$ & & - & - & - & $0.1 \%$ & - & $2(0.2)$ & $0.1 \%$ \\
\hline Reformed, dissenting & - & - & & $1(0.4)$ & - & - & $0.5 \%$ & - & $2(0.2)$ & $1.3 \%$ \\
\hline French Church & $15(9.6)$ & $20(16.7)$ & & $11(4.3)$ & $32(11.6)$ & $14(10.4)$ & $0.9 \%$ & $8(7.0)$ & $77(6.7)$ & $0.7 \%$ \\
\hline Lutherans & $11(7.0)$ & $4(3.3)$ & $6.5 \%$ & $24(9.5)$ & $20(7.2)$ & $9(6.7)$ & $4.4 \%$ & $7(6.1)$ & $82(7.1)$ & $3.8 \%$ \\
\hline Arminians & $41(26.1)$ & $16(13.3)$ & $1.5 \%$ & $28(11.1)$ & $36(13.0)$ & $24(17.9)$ & $1.1 \%$ & $13(11.3)$ & $98(8.5)$ & $1.1 \%$ \\
\hline Mennonites & $4(2.5)$ & $2(1.7)$ & $0.2 \%$ & $2(0.9)$ & $5(1.8)$ & $1(0.7)$ & $0.4 \%$ & $1(0.9)$ & $23(2.0)$ & $0.4 \%$ \\
\hline Old/Roman Catholics & $16(10.2)$ & $23(19.2)$ & $28.0 \%$ & $41(16.2)$ & $49(17.8)$ & $21(15.7)$ & $30.8 \%$ & $16(13.9)$ & $201(17.5)$ & $30.5 \%$ \\
\hline Jewish & - & - & $3.5 \%$ & $5(2.0)$ & $14(5.1)$ & $9(6.7)$ & $4.1 \%$ & $9(7.8)$ & $84(7.3)$ & $4.4 \%$ \\
\hline None & - & - & - & - & $1(0.4)$ & - & $0.03 \%$ & - & $6(0.5)$ & $0.4 \%$ \\
\hline Not relevant & - & - & - & - & - & - & - & $1(0.9)$ & $10(0.9)$ & - \\
\hline Unknown & $14(8.9)$ & $17(14.2)$ & - & $11(4.3)$ & $7(2.5)$ & $1(0.7)$ & - & - & $26(2.3)$ & - \\
\hline $\begin{array}{l}\text { cohort \& } \\
\text { perc. Inhabitants } \rightarrow \\
\text { religions } \downarrow\end{array}$ & $\begin{array}{l}\text { City \% } \\
1893\end{array}$ & $\begin{array}{l}\text { drama } \\
1890-95 \\
N=582\end{array}$ & $\begin{array}{l}\text { city \% } \\
1908\end{array}$ & $\begin{array}{l}\text { drama } \\
1902-12 \\
N=1476\end{array}$ & $\begin{array}{l}\text { opera } \\
1909-11 \\
N=677\end{array}$ & & & & & \\
\hline Dutch Reformed & $57.8 \%$ & $257(44.2)$ & $58.3 \%$ & $623(42.2)$ & $302(44.6)$ & & & & & \\
\hline English Church & $0.1 \%$ & $1(0.2)$ & $0.04 \%$ & - & $1(0.1)$ & & & & & \\
\hline Scottish Church & $0.04 \%$ & - & $0.01 \%$ & $1(0.1)$ & - & & & & & \\
\hline Reformed, dissenting & $2.3 \%$ & $2(0.3)$ & $6.8 \%$ & $5(0.3)$ & $9(1.3)$ & & & & & \\
\hline French Church & $0.4 \%$ & $35(6.0)$ & $0.2 \%$ & $68(4.6)$ & $20(3.0)$ & & & & & \\
\hline Lutherans & $3.1 \%$ & $39(6.7)$ & $2.3 \%$ & $95(6.4)$ & $59(8.7)$ & & & & & \\
\hline Arminians & $1.1 \%$ & $61(10.5)$ & $0.9 \%$ & $168(11.4)$ & $70(10.3)$ & & & & & \\
\hline Mennonites & $0.4 \%$ & $7(1.2)$ & $0.3 \%$ & $22(1.5)$ & $16(2.4)$ & & & & & \\
\hline Old/Roman Catholics & $29.9 \%$ & $91(15.6)$ & $26.2 \%$ & $222(15.0)$ & $95(14.0)$ & & & & & \\
\hline Jewish & $3.5 \%$ & $74(12.7)$ & $2.6 \%$ & $207(14.0)$ & $63(9.3)$ & & & & & \\
\hline None & $1.3 \%$ & $8(1.4)$ & $2.2 \%$ & $22(1.5)$ & $21(3.1)$ & & & & & \\
\hline Not relevant & - & $1(0.2)$ & - & $4(0.3)$ & - & & & & & \\
\hline Unknown & - & $6(1.0)$ & - & $39(2.6)$ & $21(3.1)$ & & & & & \\
\hline
\end{tabular}


Table 4a. Political and Social Functions

\begin{tabular}{|c|c|c|c|c|c|c|c|c|c|c|}
\hline & $1789-92$ & $1817-42$ & $1850-59$ & $1860-82$ & $1909-11$ & $1773-92$ & $1824-30$ & $1867-68$ & $1890-94$ & $1902-12$ \\
\hline & Opera & Opera & 'Opera' & Opera & Opera & Drama & Drama & Drama & Drama & Drama \\
\hline & $N=120$ & $N=276$ & $N=134$ & $N=1186$ & $N=677$ & $N=157$ & $N=253$ & $N=115$ & $N=582$ & $N=1476$ \\
\hline Administration & 23 & 22 & 9 & 17 & 2 & 15 & 4 & 2 & 2 & 3 \\
\hline Civil & 7 & 25 & 19 & 75 & 5 & 13 & 24 & 20 & 17 & 40 \\
\hline Cultural & & 4 & 3 & 16 & 2 & & 1 & 2 & 8 & 7 \\
\hline Economic & 43 & 52 & 37 & 142 & 29 & 31 & 22 & 23 & 48 & 62 \\
\hline Education & 1 & 58 & 42 & 137 & 38 & & 17 & 12 & 62 & 94 \\
\hline Financial & 16 & 118 & 91 & 385 & 49 & 11 & 46 & 53 & 120 & 152 \\
\hline Juridical & 7 & 2 & 1 & 3 & -- & 4 & 1 & 1 & & 2 \\
\hline Church & 16 & 88 & 65 & 256 & 62 & 13 & 33 & 23 & 58 & 115 \\
\hline Social & & 18 & 21 & 124 & 25 & & 4 & 24 & 53 & 72 \\
\hline Military & 57 & 34 & 22 & 103 & 22 & 45 & 24 & 18 & 55 & 59 \\
\hline Political & 63 & 145 & 70 & 169 & 29 & 32 & 47 & 22 & 38 & 73 \\
\hline Charitative & 6 & 165 & 95 & 309 & 42 & 3 & 72 & 52 & 95 & 113 \\
\hline Sum functions & 239 & 731 & 475 & 1736 & 305 & 169 & 295 & 252 & 556 & 792 \\
\hline Sum persons: & $71 \quad(59.2 \%)$ & $169(61.2 \%)$ & $96(71.6 \%)$ & $542(45.7 \%)$ & $137(20.2 \%)$ & $68(43.3 \%)$ & $99(39.1 \%)$ & $71(61.7 \%)$ & $230(39.5 \%)$ & $353(23.9 \%)$ \\
\hline Functions/persons & 3.4 & 4.3 & 4.9 & 3.2 & 2.2 & 2.5 & 3.0 & 3.5 & 2.4 & 2.2 \\
\hline Functions/cohort & 1.9 & 2.6 & 3.5 & 1.5 & 0.5 & 1.1 & 1.2 & 2.2 & 1.0 & 0.5 \\
\hline \multicolumn{11}{|c|}{ Function Level (sum total of functionss) } \\
\hline International & $3(1.3 \%)$ & $11(1.5 \%)$ & $21(4.4 \%)$ & $90(5.1 \%)$ & $22(7.2 \%)$ & $3(1.8 \%)$ & $6(2.0 \%)$ & $12(4.8 \%)$ & $21(3.8 \%)$ & $49(6.2 \%)$ \\
\hline National & $19(8.1 \%)$ & $45(6.2 \%)$ & $34(7.2 \%)$ & $147(8.5 \%)$ & $22(7.2 \%)$ & $5(3.0 \%)$ & $12(4.4 \%)$ & $19(7.5 \%)$ & $40(7.2 \%)$ & $54(6.8 \%)$ \\
\hline Province & $5 \quad(2.1 \%)$ & $23(3.2 \%)$ & $9(1.9 \%)$ & $30(1.7 \%)$ & $3 \quad(1.0 \%)$ & $3(1.8 \%)$ & $4(1.4 \%)$ & $4(1.6 \%)$ & $5(0.9 \%)$ & $18(2.3 \%)$ \\
\hline Regional & $17(7.2 \%)$ & $12(1.7 \%)$ & $4 \quad(0.8 \%)$ & $15(0.9 \%)$ & $2(0.7 \%)$ & $15(8.9 \%)$ & $3(1.0 \%)$ & $3(1.2 \%)$ & $1(0.2 \%)$ & $7(0.9 \%)$ \\
\hline City & $191(81.3 \%)$ & $635(87.5 \%)$ & $407(85.7 \%)$ & $1454(84.8 \%)$ & $256(83.9 \%)$ & $143(84.6 \%)$ & $269(91.2 \%)$ & $214(84,9 \%)$ & $489(87.9 \%)$ & $664(83.8 \%)$ \\
\hline
\end{tabular}


Table 5a. Sociability

\begin{tabular}{|c|c|c|c|c|c|c|c|c|c|c|}
\hline & $\begin{array}{l}1789-92 \\
\text { Opera } \\
N=120\end{array}$ & $\begin{array}{l}1817-42 \\
\text { Opera } \\
N=276\end{array}$ & $\begin{array}{c}1850-59 \\
\text { 'Opera' } \\
N=134\end{array}$ & $\begin{array}{l}1860-82 \\
\text { Opera } \\
N=1186\end{array}$ & $\begin{array}{l}\text { 1909-11 } \\
\text { Opera } \\
N=677\end{array}$ & $\begin{array}{l}1773-92 \\
\text { Drama } \\
N=157\end{array}$ & $\begin{array}{l}1824-30 \\
\text { Drama } \\
N=253\end{array}$ & $\begin{array}{l}1867-68 \\
\text { Drama } \\
N=115\end{array}$ & $\begin{array}{l}1890-95 \\
\text { Drama } \\
N=582\end{array}$ & $\begin{array}{l}1902-12 \\
\text { Drama } \\
N=1476\end{array}$ \\
\hline Cultural & 17 & 256 & 173 & 1304 & 336 & 4 & 136 & 151 & 657 & 960 \\
\hline Cultural/political & 13 & 3 & 7 & 74 & 18 & 4 & 7 & - & 52 & 57 \\
\hline Sociability & 31 & 185 & 85 & 362 & 68 & 20 & 61 & 46 & 123 & 172 \\
\hline Literary & 31 & 21 & 14 & 43 & 4 & 29 & 7 & 8 & 21 & 24 \\
\hline Social & 5 & 74 & 75 & 811 & 135 & 1 & 24 & 90 & 335 & 390 \\
\hline Musical & 10 & 12 & 6 & 169 & 186 & - & 4 & 11 & 157 & 384 \\
\hline Paining/drawing & - & 9 & 2 & 1 & - & 1 & 4 & - & - & - \\
\hline Sports & - & 4 & 2 & 24 & 2 & - & 1 & 6 & 3 & 9 \\
\hline Theatre & & 2 & - & 3 & 1 & - & 1 & 2 & - & 10 \\
\hline Scientific & 2 & 11 & 11 & 75 & 32 & 3 & 3 & 11 & 60 & 78 \\
\hline Sum Membership: & 109 & 577 & 375 & 2866 & 782 & 40 & 248 & 325 & 1408 & 2084 \\
\hline Sum persons: & $56 \quad(46.7 \%)$ & $196(71.0 \%)$ & $112(83.6 \%)$ & $910(76.7 \%)$ & 297 (43.9\%) & $62(39.5 \%)$ & $104(41.1 \%)$ & $101(87.8 \%)$ & $443(76.1 \%)$ & $760(51.5 \%)$ \\
\hline Membership/persons & 1.9 & 2.9 & 3.3 & 3.1 & 2.6 & 1.6 & 2.4 & 3.2 & 3.2 & 2.7 \\
\hline Membership/cohort & 0.9 & 2.1 & 2.8 & 2.4 & 1.2 & 0.3 & 1.0 & 2.8 & 2.4 & 1.4 \\
\hline
\end{tabular}


Table 6a. Education and Political Allegiance after 1860

\begin{tabular}{|c|c|c|c|c|c|}
\hline & $\begin{array}{l}1860-82 \\
\text { Opera } \\
\mathrm{N}=1186\end{array}$ & $\begin{array}{l}1909-11 \\
\text { Opera } \\
\mathrm{N}=677\end{array}$ & $\begin{array}{l}1867-68 \\
\text { Drama } \\
\mathrm{N}=115\end{array}$ & $\begin{array}{l}1890-94 \\
\text { Drama } \\
\mathrm{N}=582\end{array}$ & $\begin{array}{l}1902-12 \\
\text { Drama } \\
\mathrm{N}=1476\end{array}$ \\
\hline Sum Higher Education & $108(9.1 \%)$ & $59(8.7 \%)$ & $6(5.2 \%)$ & $57(9.8 \%)$ & $99(6.7 \%)$ \\
\hline Sum Gymnasium related & $60(5.1 \%)$ & $13(1.9 \%)$ & $7(6.1 \%)$ & $26(4.5 \%)$ & $38(2.6 \%)$ \\
\hline Sum 5-Burgherschool related & $15(1.3 \%)$ & $31(4.6 \%)$ & - & $32(5.5 \%)$ & $74(5.0 \%)$ \\
\hline Sum 3-Burgherschool related & - & $15(2.2 \%)$ & - & $15(2.6 \%)$ & $62(4.2 \%)$ \\
\hline Teacher Training & $3(0.3 \%)$ & $35(5.2 \%)$ & $1(0.9 \%)$ & $3(0.5 \%)$ & $21(1.4 \%)$ \\
\hline Boarding School & $6(0.5 \%)$ & $4(0.6 \%)$ & - & $1(0.2 \%)$ & $3(0.2 \%)$ \\
\hline Different/Not relevant & $10(0.9 \%)$ & - & $1(0.9 \%)$ & $1(0.2 \%)$ & $4(0.3 \%)$ \\
\hline Sum Total & $202(17 \%)$ & $157(23.2 \%)$ & $15(13.0 \%)$ & $135(23.2 \%)$ & $304(20.6 \%)$ \\
\hline Unknown & $984(83 \%)$ & $520(76.8 \%)$ & $100(87.0 \%)$ & $447(76.8 \%)$ & $1172(79.4 \%)$ \\
\hline
\end{tabular}

\section{Political Allegiance}

$\begin{array}{llllll}\text { Conservative Election Club } & 13(1.1 \%) & - & 2(1.7 \%) & - & - \\ \text { Liberal Election Club } & 175(14.8 \%) & 20(3.0 \%) & 27(23.5 \%) & 64(11.0 \%) & 56(3.8 \%) \\ \text { Christen Democrats } & 4(0.3 \%) & - & - & - & 6(0.4 \%) \\ \text { Not Relevant } & 9(0.8 \%) & - & 1(0.9 \%) & 1(0.2 \%) & 4(0.3 \%) \\ \text { Unknown } & 985(83.1 \%) & 653(96.5 \%) & 85(73.9 \%) & 517(88.8 \%) & 1410(95.5 \%)\end{array}$




\section{Table 7a. Occupation per Generation}

Opera 1817-1844

\begin{tabular}{|c|c|c|c|c|c|c|c|c|c|c|c|c|c|}
\hline & \multicolumn{2}{|c|}{ Trade } & \multicolumn{2}{|c|}{ Middle class } & \multicolumn{2}{|c|}{ Academics } & \multicolumn{2}{|c|}{ Professionals } & \multicolumn{2}{|c|}{ Workers } & \multicolumn{2}{|c|}{ None } & \multirow{2}{*}{$\begin{array}{l}\text { Sum } \\
\mathrm{N}\end{array}$} \\
\hline & $\mathrm{N}$ & $\%$ & $\mathrm{~N}$ & $\%$ & $\mathrm{~N}$ & $\%$ & $\mathrm{~N}$ & $\%$ & $\mathrm{~N}$ & $\%$ & $\mathrm{~N}$ & $\%$ & \\
\hline subscriber & 169 & 61.9 & 13 & 4.7 & 43 & 15.6 & 35 & 12.7 & - & - & 16 & 5.8 & 276 \\
\hline father & 105 & 59.0 & 15 & 8.4 & 14 & 7.9 & 24 & 13.5 & - & - & 20 & 11.2 & 178 \\
\hline grandfather & 72 & 72.7 & 4 & 4.0 & 4 & 4.0 & 6 & 6.1 & - & - & 13 & 13.1 & 99 \\
\hline great-grandfather & 23 & 67.6 & 2 & 5.9 & - & - & 5 & 14.7 & 1 & 2.9 & 3 & 8.8 & 34 \\
\hline
\end{tabular}

Drama 1824-1830

\begin{tabular}{|c|c|c|c|c|c|c|c|c|c|c|c|c|c|}
\hline & \multicolumn{2}{|c|}{ Trade } & \multicolumn{2}{|c|}{ Middle class } & \multicolumn{2}{|c|}{ Academics } & \multicolumn{2}{|c|}{ Professionals } & \multicolumn{2}{|c|}{ Workers } & \multicolumn{2}{|c|}{ None } & \multirow{2}{*}{$\begin{array}{l}\text { Sum } \\
\mathrm{N}\end{array}$} \\
\hline & $\mathrm{N}$ & $\%$ & $\mathrm{~N}$ & $\%$ & $\mathrm{~N}$ & $\%$ & $\mathrm{~N}$ & $\%$ & $\mathrm{~N}$ & $\%$ & $\mathrm{~N}$ & $\%$ & \\
\hline subscriber & 141 & 55.7 & 40 & 15.8 & 16 & 6.3 & 39 & 15.4 & - & - & 17 & 6.7 & 253 \\
\hline father & 85 & 47.8 & 36 & 20.2 & 8 & 4.5 & 17 & 9.6 & 4 & 2.2 & 28 & 15.7 & 178 \\
\hline grandfather & 39 & 50.0 & 8 & 10.3 & 7 & 9.0 & 3 & 3.8 & - & - & 21 & 26.9 & 78 \\
\hline
\end{tabular}


Opera, 1860-1882

\begin{tabular}{|c|c|c|c|c|c|c|c|c|c|c|c|c|c|}
\hline & \multicolumn{2}{|c|}{ Trade } & \multicolumn{2}{|c|}{ Middle class } & \multicolumn{2}{|c|}{ Academics } & \multicolumn{2}{|c|}{ Professionals } & \multicolumn{2}{|c|}{ Workers } & \multicolumn{2}{|c|}{ None } & \multirow{2}{*}{$\begin{array}{l}\text { Sum } \\
\mathrm{N}\end{array}$} \\
\hline & $\mathrm{N}$ & $\%$ & $\mathrm{~N}$ & $\%$ & $\mathrm{~N}$ & $\%$ & $\mathrm{~N}$ & $\%$ & $\mathrm{~N}$ & $\%$ & $\mathrm{~N}$ & $\%$ & \\
\hline subscriber & 656 & 55.3 & 176 & 14.9 & 103 & 8.7 & 143 & 12.1 & 1 & 0.1 & 107 & 9.0 & 1186 \\
\hline father & 318 & 57.3 & 106 & 19.1 & 30 & 5.4 & 78 & 14.0 & 9 & 1.6 & 14 & 2.5 & 555 \\
\hline grandfather & 158 & 52.8 & 54 & 18.1 & 12 & 4.0 & 25 & 8.4 & 18 & 6.0 & 32 & 10.7 & 299 \\
\hline great-grandfather & 74 & 71.8 & 3 & 2.9 & 3 & 2.9 & 8 & 7.8 & 1 & 1.0 & 14 & 13.6 & 103 \\
\hline great-great-grandfather & 27 & 67.5 & 2 & 5.0 & 5 & 12.5 & - & - & 1 & 2.5 & 5 & 12.5 & 40 \\
\hline
\end{tabular}

\section{Tivoli, 1890-1895}

\begin{tabular}{|c|c|c|c|c|c|c|c|c|c|c|c|c|c|}
\hline & $\mathrm{N}$ & $\%$ & $\mathrm{~N}$ & $\%$ & $\mathrm{~N}$ & $\%$ & $\mathrm{~N}$ & $\%$ & $\mathrm{~N}$ & $\%$ & $\mathrm{~N}$ & $\%$ & $\mathrm{~N}$ \\
\hline subscriber & 304 & 52.2 & 83 & 14.3 & 56 & 9.6 & 89 & 15.3 & 4 & 0.7 & 46 & 7.9 & 582 \\
\hline father & 160 & 49.1 & 80 & 24.5 & 22 & 6.7 & 48 & 14.7 & 10 & 3.1 & 6 & 1.8 & 326 \\
\hline grandfather & 84 & 43.1 & 57 & 29.2 & 5 & 2.5 & 21 & 10.1 & 21 & 10.8 & 7 & 3.6 & 195 \\
\hline great-grandfather & 43 & 64.2 & 9 & 13.4 & 1 & 1.5 & 2 & 3.0 & 5 & 7.5 & 7 & 10.4 & 67 \\
\hline great-great grandfather & 17 & 56.7 & 3 & 10.0 & 2 & 6.7 & 3 & 10.0 & 1 & 3.3 & 4 & 13.3 & 30 \\
\hline
\end{tabular}

Drama, 1902-1912

\begin{tabular}{|c|c|c|c|c|c|c|c|c|c|c|c|c|c|}
\hline & \multicolumn{2}{|c|}{ Trade } & \multicolumn{2}{|c|}{ Middle class } & \multicolumn{2}{|c|}{ Academics } & \multicolumn{2}{|c|}{ Professionals } & \multicolumn{2}{|c|}{ Workers } & \multicolumn{2}{|c|}{ None } & \multirow[t]{2}{*}{ Sum } \\
\hline & $\mathrm{N}$ & $\%$ & $\mathrm{~N}$ & $\%$ & $\mathrm{~N}$ & $\%$ & $\mathrm{~N}$ & $\%$ & $\mathrm{~N}$ & $\%$ & $\mathrm{~N}$ & $\%$ & \\
\hline subscriber & 594 & 40.2 & 242 & 16.4 & 83 & 5.6 & 331 & 22.4 & 16 & 1.1 & 210 & 14.2 & 1476 \\
\hline father & 357 & 44.8 & 233 & 29.2 & 26 & 3.3 & 129 & 16.2 & 37 & 4.6 & 15 & 1.9 & 797 \\
\hline grandfather & 184 & 39.0 & 154 & 32.6 & 11 & 2.3 & 68 & 14.4 & 37 & 7.8 & 18 & 3.8 & 472 \\
\hline great-grandfather & 84 & 60.0 & 20 & 14.3 & 7 & 5.0 & 5 & 3.6 & 11 & 7.9 & 13 & 9.3 & 140 \\
\hline great-great grandfather & 40 & 71.4 & 2 & 3.5 & 4 & 7.0 & 2 & 3.5 & 1 & 1.8 & 7 & 12.3 & 56 \\
\hline
\end{tabular}


Table 7b. Wealth Class and Occupation per Generation. Opera, 1860-82

\section{wealth class $\rightarrow$ \\ occupation \& generation $\downarrow$}

$\begin{array}{lll}\text { trade } & \mathbf{1} & \mathbf{2} \\ \text { gen } 1 & 1 & 46\end{array}$

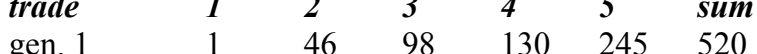

gen. $2-\begin{array}{lllll}1 & 93 & 79 & 73 & 246\end{array}$

$\begin{array}{lllllll}\text { gen. } 3 & - & 1 & 43 & 49 & 22 & 115\end{array}$

$\begin{array}{lllllll}\text { gen. } 4 \quad-\quad & - & 10 & 12 & 8 & 30\end{array}$

$\begin{array}{lllllll}\text { gen. } 5 & - & - & - & 1 & 2 & 3\end{array}$

$\begin{array}{lllllll}\text { middle class } & 1 & 2 & 3 & 4 & 5 & \text { sum }\end{array}$ $\begin{array}{lllllll}\text { gen. } 1 & 1 & 28 & 69 & 43 & 16 & 157\end{array}$ $\begin{array}{lllllll}\text { gen. } 2 & 1 & 6 & 57 & 5 & 1 & 70\end{array}$

$\begin{array}{lllllll}\text { gen. } 3 \quad 5 & - & 5 & 2 & - & 25\end{array}$

No data for generations 4 and 5

$\begin{array}{lllllll}\text { academics } & \mathbf{1} & \mathbf{2} & \mathbf{3} & \mathbf{4} & \mathbf{5} & \text { sum } \\ \text { gen. 1 } & 1 & 11 & 15 & 25 & 36 & 88 \\ \text { gen. 2 } & - & - & 5 & 10 & 12 & 27 \\ \text { gen. 3 } & - & - & 1 & 3 & 2 & 6 \\ \text { gen. 4 } & - & - & - & - & - & - \\ \text { gen. 5 } & - & - & - & 1 & - & 1\end{array}$

$\begin{array}{llllllll}\text { professionals } 1 & 2 & 3 & 4 & 5 & \text { sum }\end{array}$ $\begin{array}{lllllll}\text { gen. } 1 & 1 & 37 & 39 & 18 & 8 & 103\end{array}$ $\begin{array}{lllllll}\text { gen. } 2 & - & 3 & 30 & 7 & 1 & 41\end{array}$

$\begin{array}{lllllll}\text { gen. } 3 & - & 5 & 7 & 1 & - & 13\end{array}$

$\begin{array}{lllllll}\text { gen. } 4 & - & 1 & 1 & - & 1 & 3\end{array}$

No data for generation 5

$\begin{array}{lllllll}\text { work. class } & 1 & 2 & 3 & 4 & 5 & \text { sum }\end{array}$ $\begin{array}{lllllll}\text { gen. } 1 & - & 1 & - & - & - & 1\end{array}$ gen. 2

No data for generations 3,4 , and 5

$\begin{array}{lllllll}\begin{array}{l}\text { none } \\ \text { gen. 1 }\end{array} & \mathbf{1} & \mathbf{2} & \mathbf{3} & \mathbf{4} & \mathbf{5} & \text { sum } \\ \text { gen. 2 } & - & 5 & 7 & 11 & 21 & 45 \\ \text { gen. 3 } & - & 1 & 5 & 4 & 3 & 11 \\ \text { gen. 4 } & - & - & 1 & - & 2 & 3 \\ \text { No data for generation 5 } & & & & \\ \text { Sum } & \mathbf{1} & \mathbf{2} & \mathbf{3} & \mathbf{4} & \mathbf{5} & \text { sum } \\ \text { gen. 1 } & 5 & 127 & 229 & 227 & 325 & 905 \\ \text { gen. 2 } & 1 & 11 & 187 & 102 & 88 & 389 \\ \text { gen. 3 } & - & 12 & 74 & 57 & 27 & 170 \\ \text { gen. 4 } & - & 1 & 12 & 12 & 11 & 36 \\ \text { gen. 5 } & - & - & - & 2 & 2 & 4\end{array}$

\begin{tabular}{llllll}
\multicolumn{7}{c}{ percentages: } \\
$\mathbf{1}$ & $\mathbf{2}$ & $\mathbf{3}$ & $\mathbf{4}$ & $\mathbf{5}$ & sum \\
0.1 & 5.0 & 10.7 & 14.2 & 26.8 & 57.0 \\
- & 0.3 & 23.9 & 20.3 & 18.8 & 63.2 \\
- & 0.6 & 24.9 & 28.3 & 12.7 & 66.5 \\
- & - & 27.8 & 33.3 & 22.2 & 83.3 \\
- & - & - & 25 & 50 & 75 \\
\multicolumn{7}{l}{ percentages } & & & & \\
0.1 & 3.1 & 7.6 & 4.7 & 1.8 & 17.2 \\
0.3 & 1.5 & 14.7 & 1.3 & 0.3 & 18 \\
- & 2.9 & 10.4 & 1.6 & - & 14.5
\end{tabular}

\section{percentages}

$\begin{array}{llllll}0.1 & 1.2 & 1.6 & 2.7 & 3.9 & 9.6\end{array}$

$\begin{array}{llllll}- & - & 1.3 & 2.6 & 3.1 & 6.9\end{array}$

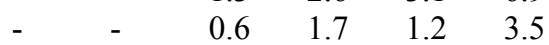

$\begin{array}{lllll}- & - & - & - & - \\ - & - & - & 25.0 & -\end{array}$

percentages

$\begin{array}{llllll}0.1 & 4.1 & 4.3 & 2.0 & 0.9 & 11.3\end{array}$

$\begin{array}{llllll}- & 0.8 & 7.7 & 1.8 & 0.3 & 10.5\end{array}$

$\begin{array}{llllll}- & 2.9 & 4.1 & 0.6 & - & 7.5\end{array}$

$\begin{array}{llllll}- & 2.8 & 2.8 & - & 2.8 & 8.3\end{array}$

percentages

$\begin{array}{llllll}- & 0.1 & - & - & - & 0.1 \\ - & 0.3 & - & - & - & 0.3\end{array}$

percentages

$\begin{array}{llllll}0.1 & 0.5 & 0.8 & 1.2 & 2.3 & 4.9\end{array}$

$\begin{array}{llllll}- & - & 0.5 & 0.3 & 0.3 & 0.8\end{array}$

$\begin{array}{llllll}- & 0.6 & 2.9 & 1.2 & 1.7 & 6.3\end{array}$

$\begin{array}{lllll}- & 2.8 & - & 5.6 & 8.3\end{array}$


Table 7c. Wealth Class and Occupation per Generation. Drama, 1902-12

\begin{tabular}{|c|c|c|c|c|c|c|c|c|c|c|c|c|}
\hline \multicolumn{13}{|c|}{$\overrightarrow{\text { wealth class } \rightarrow}$} \\
\hline \multicolumn{8}{|c|}{ occupation \& generation $\downarrow$} & \multicolumn{5}{|c|}{ percentages } \\
\hline trade & 1 & 2 & 3 & 4 & 5 & sum & 1 & 2 & 3 & 4 & 5 & sum \\
\hline gen. 1 & 9 & 44 & 130 & 87 & 282 & 553 & 0.7 & 3.5 & 10.4 & 7.0 & 22.6 & 44.2 \\
\hline gen. 2 & 2 & 43 & 39 & 58 & 100 & 242 & 0.4 & 9.2 & 8.4 & 12.5 & 21.5 & 52.0 \\
\hline gen. 3 & 1 & 2 & 33 & 42 & 33 & 122 & 0.4 & 0.8 & 13.4 & 17.1 & 13.4 & 49.6 \\
\hline gen. 4 & - & 1 & 16 & 20 & 15 & 52 & - & 1.4 & 22.2 & 27.8 & 20.8 & 72.2 \\
\hline gen. 5 & - & - & 3 & 5 & 4 & 12 & - & - & 20.0 & 33.3 & 26.7 & 80.0 \\
\hline middle class & 1 & 2 & 3 & 4 & 5 & sum & \multicolumn{6}{|c|}{ percentages } \\
\hline gen. 1 & 18 & 48 & 82 & 37 & 36 & 221 & 1.4 & 3.8 & 6.6 & 3.0 & 2.9 & 17.7 \\
\hline gen. 2 & 7 & 70 & 41 & 18 & 2 & 138 & 1.5 & 15.1 & 8.8 & 3.9 & 0.4 & 29.7 \\
\hline gen. 3 & 2 & 13 & 68 & 1 & - & 84 & 0.8 & 5.3 & 27.6 & 0.4 & - & 34.1 \\
\hline gen. 4 & - & 2 & 7 & - & - & 10 & - & 4.2 & 9.7 & - & - & 13.9 \\
\hline \multicolumn{13}{|c|}{ No data for generation 5} \\
\hline academics & 1 & 2 & 3 & 4 & 5 & sum & \multicolumn{6}{|c|}{ percentages } \\
\hline gen. 1 & 2 & 5 & 14 & 19 & 33 & 73 & 0.2 & 0.4 & 1.1 & 1.5 & 2.6 & 5.9 \\
\hline gen. 2 & - & 5 & 5 & 3 & 5 & 18 & - & 1.1 & 1.1 & 0.6 & 1.1 & 3.9 \\
\hline gen. 3 & - & - & 3 & 2 & 2 & 7 & - & - & 1.2 & 0.8 & 0.8 & 2.8 \\
\hline gen. 4 & - & - & 3 & 2 & - & 5 & - & - & 4.2 & 2.8 & - & 6.9 \\
\hline \multicolumn{13}{|c|}{ No data for generation 5} \\
\hline professionals & 1 & 2 & 3 & 4 & 5 & sum & \multicolumn{6}{|c|}{ percentages } \\
\hline gen. 1 & 39 & 91 & 92 & 33 & 20 & 275 & 3.1 & 7.3 & 7.4 & 2.6 & 1.6 & 22.1 \\
\hline gen. 2 & 2 & 43 & 8 & 6 & 2 & 61 & 0.4 & 9.2 & 1.7 & 1.3 & 0.4 & 13.1 \\
\hline gen. 3 & 1 & 7 & 13 & 2 & - & 23 & 0.4 & 2.8 & 5.3 & 0.8 & - & 9.3 \\
\hline gen. 4 & - & 1 & - & - & - & 1 & - & 1.4 & - & - & - & 1.4 \\
\hline gen. 5 & - & - & - & 1 & - & 1 & - & - & - & 6.7 & - & 6.7 \\
\hline working class & 1 & 2 & 3 & 4 & 5 & sum & \multicolumn{6}{|c|}{ percentages } \\
\hline gen. 1 & 4 & - & 4 & - & - & 8 & 0.3 & - & 0.3 & - & - & 0.6 \\
\hline gen. 2 & - & 3 & - & - & - & 3 & - & 0.6 & - & - & - & 0.6 \\
\hline gen. 3 & 2 & 3 & - & - & - & 3 & 0.8 & 1.2 & - & - & - & 2.0 \\
\hline \multicolumn{13}{|c|}{ No data for generations 4 and 5} \\
\hline none & 1 & 2 & 3 & 4 & 5 & sum & \multicolumn{6}{|c|}{ percentages } \\
\hline gen. 1 & 13 & 26 & 29 & 22 & 28 & 118 & 1.0 & 2.1 & 2.3 & 1.8 & 2.2 & 9.5 \\
\hline gen. 2 & - & - & - & 1 & 2 & 3 & - & - & - & 0.2 & 0.4 & 0.6 \\
\hline gen. 3 & - & - & 3 & 1 & 1 & 5 & - & - & 1.2 & 0.4 & 0.4 & 2.0 \\
\hline gen. 4 & - & 1 & 1 & 1 & 1 & 4 & - & 1.4 & 1.4 & 1.4 & 1.4 & 5.6 \\
\hline gen. 5 & - & - & 1 & - & 1 & 2 & - & - & 6.7 & - & 6.7 & 13.3 \\
\hline Sum & 1 & 2 & 3 & 4 & 5 & sum & \multicolumn{6}{|c|}{ percentages } \\
\hline gen. 1 & 85 & 214 & 351 & 198 & 399 & 1247 & 6.8 & 17.2 & 28.1 & 15.9 & 32.0 & 100 \\
\hline gen. 2 & 11 & 164 & 93 & 86 & 111 & 465 & 2.4 & 35.3 & 20.0 & 18.5 & 23.9 & 100 \\
\hline gen. 3 & 6 & 25 & 131 & 48 & 36 & 246 & 2.4 & 10.2 & 53.2 & 19.5 & 14.6 & 100 \\
\hline gen. 4 & - & 6 & 27 & 23 & 16 & 72 & - & 8.3 & 37.5 & 31.9 & 22.2 & 100 \\
\hline gen. 5 & - & - & 4 & 6 & 5 & 15 & - & - & 26.7 & 40.0 & 33.3 & 100 \\
\hline
\end{tabular}


Table 7d. Wealth Class and Occupation per Generation. 'Melodrama cohort,' 1824-1830

\begin{tabular}{|c|c|c|c|c|c|c|c|c|c|c|c|c|}
\hline \multicolumn{13}{|c|}{ wealth class (rateable value) $\rightarrow$} \\
\hline trade & 1 & 2 & 3 & 4 & 5 & sum & 1 & 2 & 3 & 4 & 5 & sum \\
\hline gen. 1 & - & 1 & 53 & 44 & 20 & 118 & - & 0.5 & 27.6 & 22.9 & 10.4 & 61.4 \\
\hline gen. 2 & - & - & 15 & 19 & 8 & 42 & - & - & 21.1 & 26.8 & 11.3 & 59.2 \\
\hline gen. 3 & - & - & - & 3 & 2 & 5 & \multicolumn{6}{|c|}{ too few data to be relevant } \\
\hline middle class & 1 & 2 & 3 & 4 & 5 & sum & \multicolumn{6}{|c|}{ percentages } \\
\hline gen. 1 & - & 1 & 18 & 12 & 2 & 33 & - & 0.5 & 9.4 & 6.3 & 1.0 & 17.2 \\
\hline gen. 2 & - & 1 & 12 & 3 & - & 16 & - & 1.4 & 16.9 & 4.2 & - & 22.5 \\
\hline gen. 3 & - & - & 1 & - & - & 1 & \multicolumn{6}{|c|}{ too few data to be relevant } \\
\hline academics & 1 & 2 & 3 & 4 & 5 & sum & \multicolumn{6}{|c|}{ percentages } \\
\hline gen. 1 & - & - & 3 & 5 & 2 & 10 & - & - & 1.6 & 2.6 & 1.0 & 5.2 \\
\hline gen. 2 & - & - & 2 & 4 & - & 5 & - & - & 2.8 & 5.6 & - & 7.0 \\
\hline gen. 3 & - & - & 1 & - & - & 1 & \multicolumn{6}{|c|}{ too few data to be relevant } \\
\hline professionals & 1 & 2 & 3 & 4 & 5 & sum & \multicolumn{6}{|c|}{ percentages } \\
\hline gen. 1 & 1 & 1 & 24 & 1 & - & 27 & 0.5 & 0.5 & 12.5 & 0.5 & - & 14.1 \\
\hline gen. 2 & 1 & - & 3 & - & 1 & 5 & 1.4 & - & 4.2 & - & 1.4 & 7.0 \\
\hline No data for ge & ne & n 3 & & & & & \multicolumn{6}{|c|}{ no data } \\
\hline $\begin{array}{l}\text { work. class } \\
\text { no data }\end{array}$ & 1 & 2 & 3 & 4 & 5 & sum & \multicolumn{6}{|c|}{ percentages } \\
\hline none & 1 & 2 & 3 & 4 & 5 & sum & \multicolumn{6}{|c|}{ percentages } \\
\hline gen. 1 & - & - & 2 & 3 & 1 & 6 & - & - & 1.0 & 1.6 & 0.5 & 3.1 \\
\hline gen. 2 & - & - & 2 & - & - & 2 & - & - & 2.8 & - & - & 2.8 \\
\hline no data for ge & ner & & & & & & \multicolumn{6}{|c|}{ No data } \\
\hline Sum & 1 & 2 & 3 & 4 & 5 & sum & \multicolumn{6}{|c|}{ percentages } \\
\hline gen. 1 & 1 & 3 & 100 & 63 & 25 & 192 & 0.5 & 1.6 & 52.1 & 32.8 & 13.2 & 100 \\
\hline gen. 2 & 1 & 1 & 34 & 26 & 9 & 71 & 1.4 & 1.4 & 47.9 & 36.6 & 12.7 & 100 \\
\hline gen. 3 & - & - & 2 & 3 & 2 & 7 & \multicolumn{6}{|c|}{ too few data to be relevant } \\
\hline MTB & 0 & 3.- & 6.- & 15.- & 30.- & sum & \multicolumn{6}{|c|}{ percentages } \\
\hline gen 2 & 1 & 10 & 10 & 5 & 14 & 40 & 2.5 & 25.0 & 25.0 & 12.5 & 35.0 & 100 \\
\hline gen 3 & - & 10 & 7 & 1 & 11 & 29 & - & 34.5 & 24.1 & 3.4 & 37.9 & 100 \\
\hline
\end{tabular}


Table 2cAge

Drama, 1773-1912, and 1959

Subscribers Punt \& Corver, 1773-77

age category $\Rightarrow$

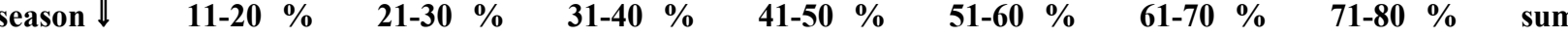

$1773-77$

$\leq 30 \quad \% \quad 31-50 \% \quad 251 \quad \%$

Subscribers Corver, 1778-79

age category $\Rightarrow$

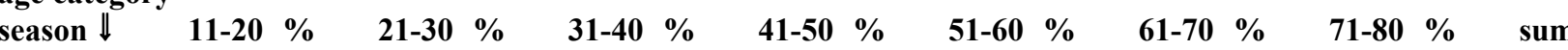

$\begin{array}{lllllllllllllll}1778-79 & 17 & 21.5 & 15 & 19.0 & 11 & 13.9 & 17 & 21.5 & 14 & 17.7 & 4 & 5.1 & 1 & 1.3\end{array}$

$\leq 30 \quad \% \quad 31-50 \quad \% \quad \geq 51 \quad \%$

Season-ticket holders Snoek, 1792-93

age category $\Rightarrow$

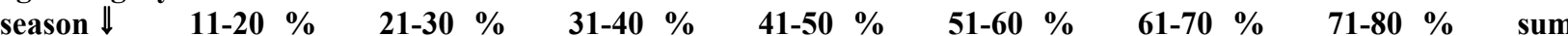

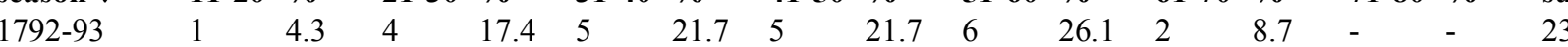

$\leq 30 \quad \% \quad 31-50 \quad \% \quad \geq 51 \quad \%$

Season-ticket holders Hoedt \& Bingley, 1824-30

age category $\Rightarrow$

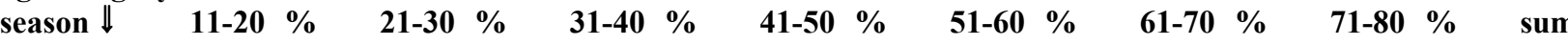

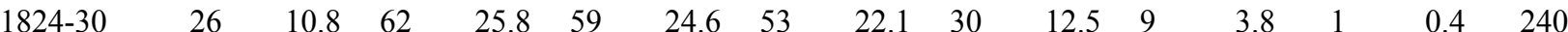

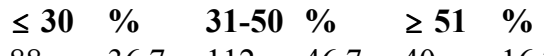

Subscribers (coupons) De Vries, 1867-68

age category $=$

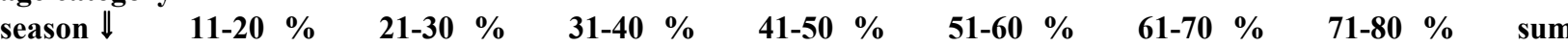

$\begin{array}{lllllllllllllll}1867-68 & - & - & 7 & 6.1 & 27 & 23.7 & 31 & 27.2 & 28 & 24.6 & 14 & 12.3 & 7 & 6.1\end{array}$

$\leq \mathbf{3 0} \quad \% \quad \mathbf{3 1 - 5 0} \% \quad \mathbf{5} \quad \%$

Subscribers (coupons) Le Gras c.s., 1876-98

age category $\Rightarrow$

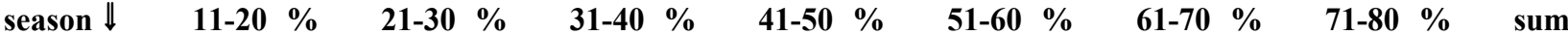

$\begin{array}{llllllllllllllll}1879-80 & - & - & 11 & 26.2 & 15 & 35.7 & 8 & 19.0 & 4 & 9.5 & 3 & 7.1 & 1 & 2.4 & 42\end{array}$

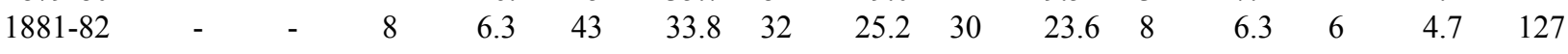

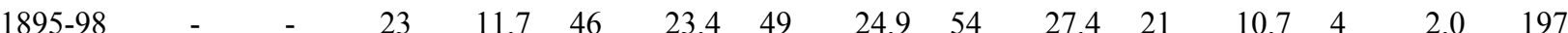

$\begin{array}{llllll}\mathbf{3} 30 & \mathbf{\%} & \mathbf{3 1 - 5 0} & \mathbf{\%} & \mathbf{2} \mathbf{5 1} & \mathbf{\%} \\ 11 & 26.2 & 23 & 54.8 & 8 & 19.0 \\ 8 & 6.3 & 65 & 51.2 & 44 & 34.6 \\ 23 & 11.7 & 95 & 48.2 & 79 & 40.1\end{array}$


Subscribers (coupons) Tivoli Theatre, De Vos \& Van Korlaar, 1890-95

\section{age category}

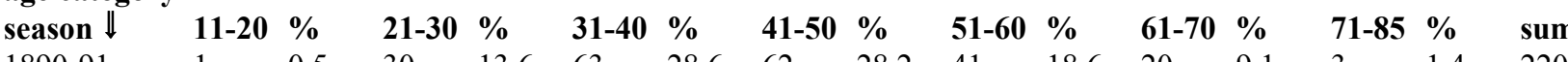

$\begin{array}{llllllllllllllll}1890-91 & 1 & 0.5 & 30 & 13.6 & 63 & 28.6 & 62 & 28.2 & 41 & 18.6 & 20 & 9.1 & 3 & 1.4 & 220\end{array}$

$\begin{array}{llllllllllllllll}1891-92 & - & - & 38 & 13.4 & 77 & 27.1 & 76 & 26.8 & 61 & 21.5 & 24 & 8.5 & 8 & 2.8 & 284\end{array}$

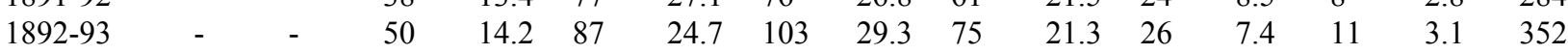

$\begin{array}{llllllllllllllll}1893-94 & 1 & 0.3 & 41 & 13.2 & 87 & 27.3 & 86 & 27.0 & 69 & 21.6 & 21 & 6.6 & 14 & 4.3 & 319\end{array}$

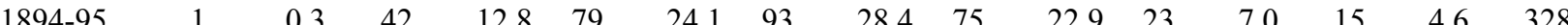

1890-95

13.379

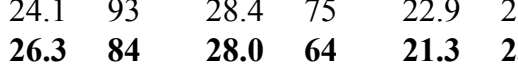

$7.7 \quad 10$

$\begin{array}{ll}4.6 & 328 \\ \mathbf{3 . 3} & \mathbf{3 0 0}\end{array}$

Subscribers (season tickets and/or coupons), Rotterdam Stage Company, Van Eijsden, 1902-1911

age category $\Rightarrow$

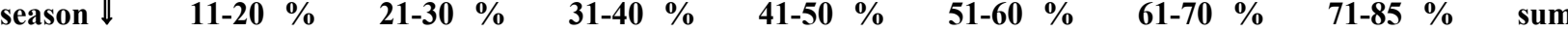

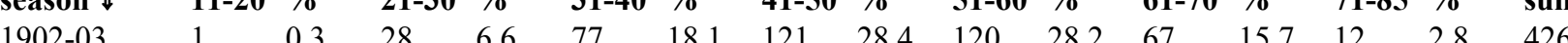

$\begin{array}{llllllllllllllll}1903-04 & 2 & 0.5 & 32 & 7.3 & 74 & 16.9 & 136 & 31.1 & 113 & 25.9 & 68 & 15.6 & 12 & 2.7 & 437\end{array}$

$\begin{array}{llllllllllllllll}1904-05 & 2 & 0.4 & 40 & 8.4 & 91 & 19.0 & 125 & 26.1 & 129 & 26.9 & 74 & 15.4 & 18 & 3.8 & 479\end{array}$

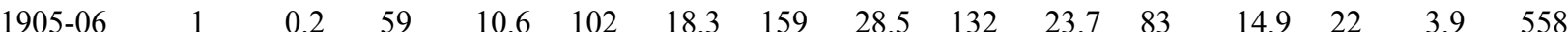

$\begin{array}{llllllllllllllll}1906-07 & 4 & 0.6 & 74 & 11.5 & 128 & 19.8 & 164 & 25.4 & 163 & 25.3 & 90 & 14.0 & 25 & 3.9 & 645\end{array}$

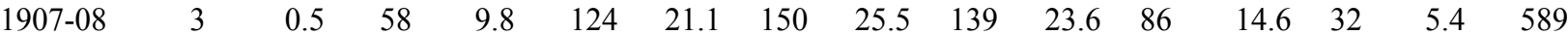

$\begin{array}{llllllllllllllll}1908-09 & - & - & 58 & 10.0 & 128 & 22.0 & 142 & 24.4 & 141 & 24.2 & 83 & 14.3 & 33 & 5.7 & 582\end{array}$

$\begin{array}{llllllllllllllll}1909-10 & 3 & 0.5 & 49 & 7.8 & 143 & 22.7 & 153 & 24.2 & 158 & 25.0 & 94 & 14.9 & 31 & 4.9 & 631\end{array}$

$\begin{array}{llllllllllllllll}1910-11 & 3 & 0.5 & 52 & 7.9 & 153 & 23.3 & 161 & 24.5 & 149 & 22.6 & 103 & 15.6 & 37 & 5.6 & 658\end{array}$

$\begin{array}{llllllllllllllll}1911-12 & 4 & 0.6 & 50 & 7.7 & 139 & 21.4 & 163 & 25.0 & 160 & 24.6 & 98 & 15.1 & 37 & 5.7 & 651\end{array}$

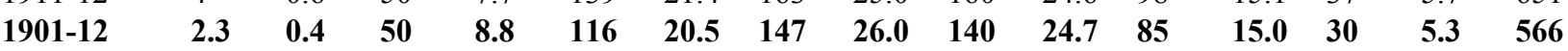

$\begin{array}{llllll}\mathbf{3} 30 & \mathbf{\%} & \mathbf{3 1 - 5 0} & \mathbf{\%} & \mathbf{2 5 1} & \mathbf{\%} \\ 31 & 14.1 & 125 & 56.8 & 64 & 29.1 \\ 38 & 13.4 & 153 & 53.9 & 93 & 32.7 \\ 50 & 14.2 & 190 & 54.0 & 112 & 31.8 \\ 42 & 13.2 & 173 & 54.3 & 104 & 32.6 \\ 43 & 13.1 & 172 & 52.4 & 113 & 34.5 \\ \mathbf{4 1} & \mathbf{1 3 . 7} & \mathbf{1 6 2} & \mathbf{5 4 . 0} & \mathbf{9 7} & \mathbf{3 2 . 3}\end{array}$

Season-tickets, Rotterdam Stage Company, Ton Lutz, c.s.

age category $\Rightarrow$

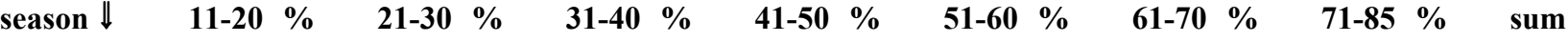

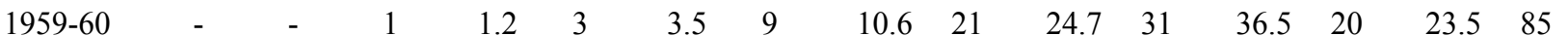

$\begin{array}{llllll}\mathbf{3 3 0} & \mathbf{\%} & \mathbf{3 1 - 5 0} & \mathbf{\%} & \mathbf{\geq} \mathbf{5 1} & \mathbf{\%} \\ 29 & 6.6 & 198 & 46.5 & 199 & 46.7 \\ 34 & 7.8 & 210 & 48.1 & 193 & 44.2 \\ 42 & 8.8 & 216 & 45.1 & 221 & 46.1 \\ 60 & 10.8 & 261 & 46.8 & 237 & 42.5 \\ 78 & 12.1 & 292 & 45.3 & 278 & 43.1 \\ 61 & 10.4 & 274 & 46.5 & 257 & 43.6 \\ 58 & 10.0 & 270 & 46.4 & 257 & 44.2 \\ 52 & 8.2 & 296 & 46.9 & 283 & 44.8 \\ 55 & 8.4 & 314 & 47.7 & 289 & 43.9 \\ 54 & 8.3 & 302 & 46.4 & 295 & 45.3 \\ \mathbf{5 2 . 3} & \mathbf{9 . 2} & \mathbf{2 6 3} & \mathbf{4 6 . 5} & \mathbf{2 5 5} & \mathbf{4 5 . 1}\end{array}$

Opera, 1789-1882, and 1933

Season-tickets Rotterdam French Opera, Denarelles and Moylin, 1789-92

age category $\Rightarrow$

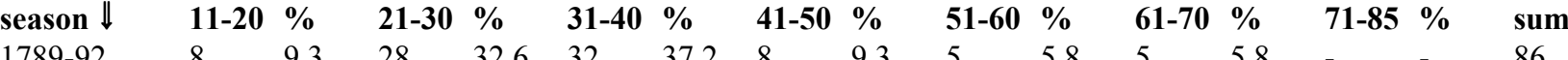

$1789-92$

$\begin{array}{llllll}\leq 30 & \% & 31-50 & \% & \geq 51 & \%\end{array}$

$\begin{array}{llllll}36 & 41.9 & 40 & 46.5 & 10 & 11.6\end{array}$ 
Season-tickets (boxes only!), French Opera The Hague, Milord, 1817-19

age category $\Rightarrow$

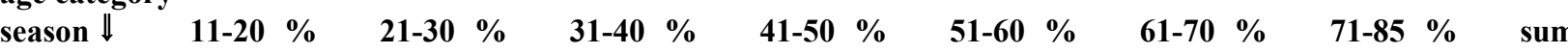

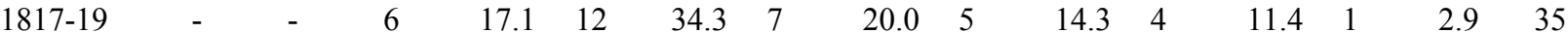

$\begin{array}{llllll}\leq 30 & \% & \mathbf{3 1 - 5 0} & \% & \mathbf{2} 51 & \%\end{array}$

Subscriptions, French Opera The Hague, Duvernoy, 1836-38

age category $\Rightarrow$

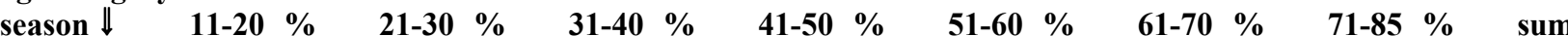

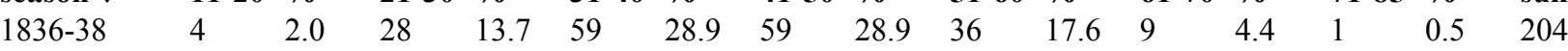

$\leq 30 \quad \% \quad 31-50 \quad \% \quad \geq 51 \quad \%$

Season-tickets Amsterdam French Opera, Renée, 1843-44

age category $\Rightarrow$

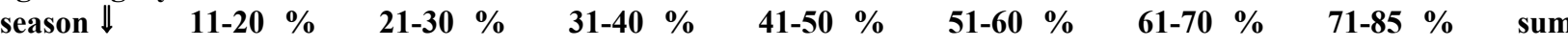

$1843-44$

Shareholder-season tickets, Rotterdam German Opera, De Vries, 1860-1

age category $\Rightarrow$

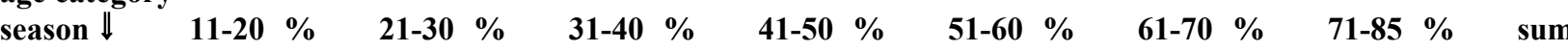

$\begin{array}{llllllllllllllll}1860-61 & 2 & 1.4 & 25 & 17.4 & 48 & 33.3 & 35 & 24.3 & 23 & 16.0 & 10 & 6.9 & 1 & 0.7 & 144\end{array}$

$\leq \mathbf{3 0} \quad \% \quad \mathbf{3 1 - 5 0} \% \quad \mathbf{2} \quad \mathbf{5 1} \%$

Members of the Support-society Rotterdam German Opera, Committee (Burger), 1865-67

age category $\Rightarrow$

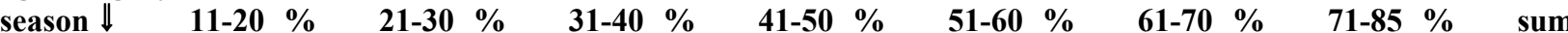

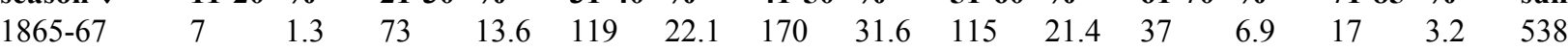

$\leq 30 \quad \% \quad 31-50 \% \quad 251 \quad \%$

Season-tickets and coupons, Rotterdam German Opera, Committee (Burger), 1867-68

age category $\Rightarrow$

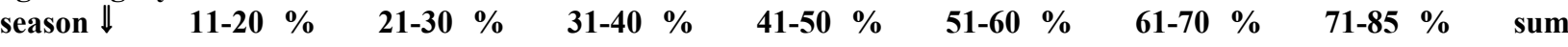

$\begin{array}{llllllllllllllll}1867-68 & 2 & 0.5 & 51 & 11.9 & 103 & 24.0 & 114 & 26.5 & 100 & 23.3 & 46 & 10.7 & 14 & 3.3 & 430\end{array}$

$\leq 30 \quad \% \quad 31-50 \quad \% \quad \geq 51 \quad \%$

Coupon-buyers Rotterdam German Opera, Carl Pflaeging, 1879-80 (probably not complete)

age category $\Rightarrow$

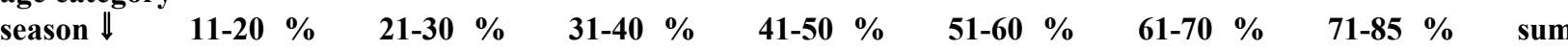

$\begin{array}{llllllllllllllll}1879-80 & 3 & 0.7 & 83 & 18.6 & 122 & 27.4 & 98 & 22.0 & 85 & 19.1 & 48 & 10.8 & 7 & 1.6 & 446\end{array}$

$\leq \mathbf{3 0} \quad \% \quad \mathbf{3 1 - 5 0} \% \quad \mathbf{5 1} \%$

Season-ticket holders Rotterdam German Opera, Carl Pflaeging, 1881-82

age category $\Rightarrow$

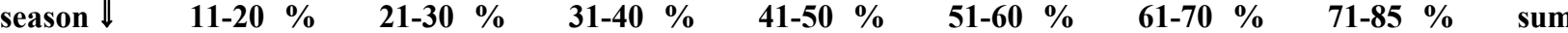

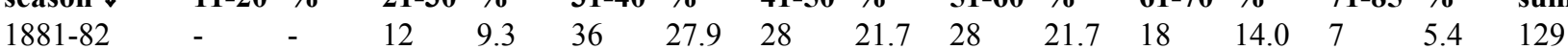

$\leq \mathbf{3 0} \quad \% \quad \mathbf{3 1 - 5 0} \% \quad \mathbf{2} \quad \mathbf{5 1} \%$

$\begin{array}{llllll}12 & 9.39 & 64 & 49.6 & 53 & 41.1\end{array}$ 
Subscribers Maifestspiele, Rotterdam, 1909-11

age category $\Rightarrow$

21-30\%

$31-40 \%$

1909-11

172.6

41-50 \%

$51-60 \%$

$\begin{array}{lllll}61-70 & \% & 71-85 & \% & \text { sum }\end{array}$

$\begin{array}{llllll}\mathbf{3 0} & \% & \mathbf{3 1 - 5 0} & \% & \mathbf{2} 51 & \%\end{array}$

Subscribers in Rotterdam, Opera Italiana, The Hague, 1933-34

age category $\Rightarrow$

$\begin{array}{llllllllllllllll}\text { season } \downarrow & \mathbf{1 1 - 2 0} & \mathbf{\%} & \mathbf{2 1 - 3 0} & \mathbf{\%} & \mathbf{3 1 - 4 0} & \mathbf{\%} & \mathbf{4 1 - 5 0} & \mathbf{\%} & \mathbf{5 1 - 6 0} & \mathbf{\%} & \mathbf{6 1 - 7 0} & \mathbf{\%} & \mathbf{7 1 - 8 5} & \% & \text { sum } \\ 1933-34 & 3 & 1.4 & 31 & 14.0 & 40 & 18.0 & 72 & 32.4 & 53 & 23.9 & 20 & 9.0 & 3 & 1.4 & 222\end{array}$

$\leq 30 \quad \% \quad 31-50 \% \quad \geq 51 \quad \%$

Subscribers Concert Erudition Musica, 1867-68

age category $\Rightarrow$

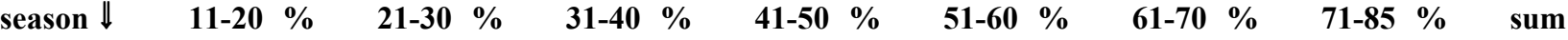

1867-68

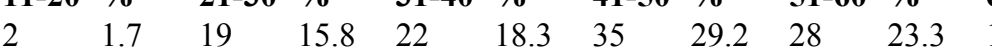

$\begin{array}{llllll}\mathbf{3} 30 & \% & \mathbf{3 1 - 5 0} & \% & \mathbf{2 5 1} & \%\end{array}$ 


\begin{tabular}{|c|c|c|c|c|c|c|c|}
\hline $\begin{array}{l}\text { wealth class } \rightarrow \\
\text { club } \downarrow\end{array}$ & 1 & 2 & 3 & 4 & 5 & \multicolumn{2}{|l|}{ sum } \\
\hline \multicolumn{8}{|l|}{$\begin{array}{l}\text { French Opera, } 1789-1792 \\
\text { not analysed = burial tax }\end{array}$} \\
\hline \multicolumn{8}{|l|}{ French Opera, 1817-1844 } \\
\hline SUM members & - & - & 83 & 178 & 243 & \multicolumn{2}{|c|}{504 of $577(87.3 \%)$} \\
\hline SUM in wealth class & - & - & 72 & 85 & 69 & \multicolumn{2}{|c|}{226 of $276(81.9 \%)$} \\
\hline mean number members & - & - & 1.2 & 2.1 & 3.5 & \multirow{3}{*}{\multicolumn{2}{|c|}{2.2}} \\
\hline$\%$ members/sum members & - & - & 16.5 & 35.3 & 48.2 & & \\
\hline$\%$ members/sum wealth & - & - & 31.8 & 37.6 & 30.5 & & \\
\hline CULTURAL & - & - & 48 & 82 & 90 & 220 & (43.7 valid \%) \\
\hline Harmony, member & - & - & 24 & 30 & 31 & 85 & \\
\hline Dutch Society & - & - & 11 & 24 & 25 & 60 & \\
\hline Reading Museum & - & - & 8 & 22 & 17 & 47 & \\
\hline CULTURAL/POLITICAL & - & - & - & 1 & 2 & 3 & $(0.6$ valid \%) \\
\hline SOCIABILITY & - & - & 16 & 59 & 89 & 164 & (32.5 valid $\%)$ \\
\hline Yacht Club & - & - & 1 & 10 & 16 & 27 & \\
\hline Amicitia \& Grand Club & - & - & 2 & 17 & 20 & 39 & \\
\hline Grand Club Amicitia & - & - & 12 & 32 & 53 & 97 & \\
\hline LITERARY & - & - & - & 9 & 10 & 19 & $(3.8$ valid \%) \\
\hline SOCIAL & - & - & 14 & 15 & 35 & 64 & $(12.7$ valid $\%)$ \\
\hline Zoo & - & - & 8 & 10 & 21 & 39 & \\
\hline Soc. Public Advancement & - & - & 4 & 4 & 11 & 19 & \\
\hline MUSIC & - & - & 2 & 4 & 3 & 9 & $(1.8$ valid \%) \\
\hline Soc.Adv. of Music & & - & - & 2 & 4 & 3 & 9 \\
\hline PAINTING/DRAWING & - & - & 2 & 3 & 3 & 8 & $(1.6$ valid \%) \\
\hline SPORT & - & - & - & - & 4 & 4 & $(0.8$ valid \%) \\
\hline THEATRE & - & - & 1 & 1 & - & 2 & $(0.4$ valid \%) \\
\hline SCIENTIFIC & - & - & - & 4 & 7 & 11 & $(2.2$ valid $\%)$ \\
\hline
\end{tabular}

wealth class $\rightarrow$

1

$\begin{array}{lllll}2 & 3 & 4 & 5 & \text { sum }\end{array}$ club $\downarrow$

German Opera, 1860-1882

$\begin{array}{lllllll}\text { SUM members } & 6 & 165 & 371 & 642 & 1265 & 2449 \text { of } 2866(85.5 \%)\end{array}$

$\begin{array}{lllllll}\text { SUM in wealth class } & 5 & 127 & 229 & 227 & 325 & 913 \text { of } 1186\end{array}$

$\begin{array}{lllllll}\text { mean number members } & 1.2 & 1.3 & 1.6 & 2.8 & 3.9 & 2.7\end{array}$

$\begin{array}{llllll}\% \text { members/sum members } & 0.3 & 6.5 & 15.3 & 26.4 & 51.6\end{array}$

$\begin{array}{llllll}\% \text { cohort/sum wealth } \quad 0.6 & 13.8 & 25.4 & 25.1 & 35.2\end{array}$

CULTURAL

Aesthetic Society

Art Circle

Harmony, member

Dutch Society

Reading Museum

Art \& Science

Art \& History

CULTURAL/POLITICAL

Rhetorical Club

SOCIABILITY

Grand Club Amicitia

Yacht Club

Concordia Felix

LITERARY

Lecture

Amicable Literary Exercise -

SOCIAL

Zoo

Soc. Public Advancement

Floralia

MUSIC

Rott.Men's Choral Soc.

Soc.Adv. of Music

PAINTING/DRAWING

SPORT

THEATRE

SCIENTIFIC

Rott.Scientific Soc

Batavian Society

\begin{tabular}{cllllll}
1 & 75 & 168 & 301 & 578 & 1123 & $(45.9$ valid \%) \\
- & 6 & 27 & 35 & 57 & 125 & \\
- & 6 & 13 & 23 & 33 & 75 & \\
- & 26 & 53 & 101 & 197 & 377 & \\
1 & 11 & 29 & 48 & 94 & 183 & \\
- & 15 & 25 & 48 & 121 & 209 & \\
- & 7 & 10 & 15 & 9 & 41 & \\
- & 3 & 2 & 16 & 33 & 54 & \\
\hline 1 & 10 & 13 & 19 & 17 & 60 & $(2.1$ valid \%) \\
1 & 6 & 6 & 14 & 11 & 38 & \\
- & 20 & 27 & 63 & 198 & 308 & $(10.7$ valid \%) \\
- & 14 & 13 & 50 & 156 & 233 & \\
- & - & 1 & 6 & 38 & 45 & \\
- & 4 & 11 & 7 & 1 & 23 & \\
- & 3 & 12 & 81 & 14 & 37 & $(1.3$ valid \%) \\
- & 3 & - & 4 & 13 & 20 & \\
- & - & 7 & 3 & 1 & 11 & \\
4 & 44 & 111 & 191 & 353 & 703 & $(24.5$ valid \%) \\
- & 6 & 25 & 43 & 104 & 178 & \\
2 & 19 & 52 & 80 & 133 & 286 & \\
2 & 11 & 22 & 36 & 70 & 141 & \\
- & 9 & 28 & 39 & 55 & 131 & $(4.5$ valid \%) \\
- & 9 & 14 & 18 & 16 & 57 & \\
- & - & 5 & 13 & 21 & 39 & $(0.03$ valid \%) \\
- & - & - & - & 1 & 1 & $(0.6$ valid \%) \\
- & - & - & 2 & 14 & 16 & $(2.4$ valid \%) \\
- & - & - & 2 & 1 & 3 & 0.11 alid \%) \\
- & 4 & 12 & 19 & 35 & 70 & \\
- & 2 & 8 & 13 & 25 & 48 & \\
- & & &
\end{tabular}


Sociability $\mathbf{x}$ wealth class, Opera

\begin{tabular}{llllllll}
\hline $\begin{array}{l}\text { wealth class } \rightarrow \\
\text { club } \downarrow\end{array}$ & 1 & 2 & 3 & 4 & 5 & Sum & \\
& & & & & & & \\
Maifestspiele, 1909-1911 & & & & & & & \\
SUM members & 16 & 36 & 105 & 86 & 492 & 735 of $782(94.0 \%)$ \\
SUM in class & 83 & 107 & 130 & 67 & 153 & 540 of $677(79.8 \%)$ \\
mean numbermembers & 0.2 & 0.3 & 0.8 & 1.3 & 3.2 & 1.4 & \\
\% members/sum members & 2.2 & 4.9 & 14.3 & 11.7 & 66.9 & & \\
\% cohort/sum wealth & 15.4 & 19.8 & 24.1 & 12.4 & 28.3 & & \\
& & & & & & & \\
& & & & & & & \\
CULTURAL & 4 & 4 & 46 & 36 & 232 & 322 & $(43.8$ valid \%) \\
Art Circle & 4 & 1 & 23 & 20 & 100 & 148 & \\
Aesthetic Society & - & 1 & 5 & 5 & 28 & 39 & \\
Harmony, member & - & 1 & 12 & 8 & 75 & 96 & \\
CULTURAL/POLITICAL & - & - & 1 & - & 14 & 15 & $(2.0$ valid \%) \\
Exercise in Speech & - & - & 1 & 14 & 11 & 38 & \\
SOCIABILITY & - & 2 & 4 & 3 & 54 & 63 & $(8.6$ valid \%) \\
Grand Club Amicitia & - & 1 & 1 & 1 & 44 & 47 & \\
LITERARY & - & - & - & - & 3 & 3 & $(0.4$ valid \%) \\
SOCIAL & 2 & 9 & 13 & 17 & 87 & 128 & $(17.4$ valid \%) \\
Soc. Public Advancement & 2 & 8 & 10 & 15 & 60 & 95 & \\
Elevation Publ.Entertainment & - & 1 & 1 & 2 & 15 & 19 & \\
MUSIC & 10 & 21 & 36 & 25 & 80 & 172 & $(23.4$ valid \%) \\
Rott.Men's Choral Soc. & 4 & 12 & 18 & 7 & 18 & 59 & \\
Soc.Adv. of Music & 3 & 6 & 13 & 14 & 50 & 86 & \\
SPORT & - & - & 1 & 1 & - & 2 & $(0.3$ valid \%) \\
SCIENTIFIC & - & - & 4 & 4 & 22 & 30 & $(4.1$ valid \%) \\
Rott.Scientific Soc. & - & - & 4 & 3 & 21 & 28 & \\
& & & & & & &
\end{tabular}




\begin{tabular}{|c|c|c|c|c|c|c|c|}
\hline $\begin{array}{l}\text { wealth class } \rightarrow \\
\text { club } \downarrow\end{array}$ & 1 & 2 & 3 & 4 & 5 & \multicolumn{2}{|l|}{ Sum } \\
\hline \multicolumn{8}{|c|}{$\begin{array}{l}\text { Hollands THEATRE, } 1773-1793 \\
\text { not analysed = burial tax }\end{array}$} \\
\hline \multicolumn{8}{|l|}{ Hoedt \& Bingley, 1824-1830 } \\
\hline SUM members & - & - & 75 & 81 & 67 & \multicolumn{2}{|c|}{223 of $248(89.9 \%)$} \\
\hline SUM in class & 1 & 3 & 100 & 63 & 25 & \multicolumn{2}{|c|}{192 of $253(75.9 \%)$} \\
\hline mean numbermembers & 0 & 0 & 0.8 & 1.3 & 2.7 & \multirow{3}{*}{\multicolumn{2}{|c|}{1.2}} \\
\hline$\%$ members/sum members & - & - & 33.6 & 36.3 & 30.0 & & \\
\hline$\%$ cohort/sum wealth & 0.5 & 1.6 & 52.1 & 32.8 & 13.0 & & \\
\hline CULTURAL & - & - & 44 & 45 & 32 & 121 & $(54.2$ valid $\%)$ \\
\hline Harmony, member & - & - & 20 & 17 & 12 & 49 & \\
\hline Dutch Society & - & - & 11 & 14 & 9 & 34 & \\
\hline Reading Museum & - & - & 6 & 10 & 7 & 23 & \\
\hline CULTURAL/POLITICAL & - & - & 1 & 5 & 1 & 7 & (3.1 valid \%) \\
\hline SOCIABILITY & - & - & 13 & 17 & 24 & 54 & $(24.2$ valid $\%)$ \\
\hline Grand Club Amicitia & - & - & 8 & 10 & 15 & 33 & \\
\hline Yacht Club & - & - & - & 1 & 3 & 4 & \\
\hline LITERARY & - & - & 5 & 1 & 1 & 7 & $(0.3$ valid $\%)$ \\
\hline SOCIAL & - & - & 8 & 7 & 6 & 21 & $(9.4$ valid \%) \\
\hline Rott.Men's Choral Soc. & - & 1 & 2 & - & 2 & 5 & \\
\hline Zoo & - & - & 6 & 5 & 50 & 16 & \\
\hline Soc. Public Advancement & - & - & 1 & 2 & 1 & 4 & \\
\hline MUSIC & - & - & 1 & 2 & 1 & 4 & $(1.8$ valid $\%)$ \\
\hline Soc.Adv. of Music & - & - & 1 & 2 & 1 & 4 & \\
\hline PAINTING/DRAWING & - & - & 1 & 3 & - & 4 & $(1.8$ valid \%) \\
\hline SPORT & - & - & - & - & 1 & 1 & $(0.4$ valid \%) \\
\hline THEATRE & - & - & 1 & - & - & 1 & $(0.4$ valid \%) \\
\hline SCIENTIFIC & - & - & 1 & 1 & 1 & 3 & $(1.3$ valid $\%)$ \\
\hline
\end{tabular}

wealth class $\rightarrow$

12

Sum

club $\downarrow$

Albregt \& of Ollefen, 1867-1868

SUM members

SUM in class

mean numbermembers

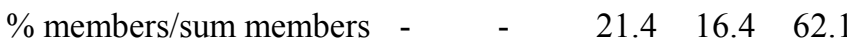

$\begin{array}{llllll}\% \text { cohort/sum wealth } & - & 9.1 & 29.3 & 18.2 & 43.4\end{array}$

\section{CULTURAL}

Harmony, member

Dutch Society

Reading Museum

SOCIABILITY

Grand Club Amicitia

Yacht Club

Concordia Felix

LITERARY

SOCIAL

Zoo

Soc. Public Advancement

MUSIC

Soc.Adv. of Music

SPORT

THEATRE

SCIENTIFIC

Rott.Scientific Soc.

-
-

-
-
-
-
-
-
-
-
-
-
-
-
-

3
-
-
1
-
-
1
-
-
-
-
1
-
-
-
-
-

$\begin{array}{lll}26 & 27 & 8 \\ 9 & 15 & 3 \\ - & 4 & 3 \\ 1 & 2 & 7 \\ 5 & 3 & 3 \\ - & 1 & 3 \\ - & - & 8 \\ 4 & - & - \\ 4 & - & 2 \\ 22 & 15 & 4 \\ 9 & 6 & 2 \\ 9 & 5 & 1 \\ 3 & 1 & 5 \\ - & 1 & 3 \\ - & 1 & 4 \\ - & 1 & 1 \\ 4 & 1 & 5 \\ 3 & 1 & 5\end{array}$
(47.7 valid \%)
23
(14.8 valid \%)
31
(2.0 valid \%)
(28.5 valid \%)
(3.3 valid \%)
(1.7 valid \%)
0.7 valid \%)
(3.4 valid \%)

(0.4 valid \%)

(1.3 valid \%) 


\begin{tabular}{llllllll}
\hline wealth class $\rightarrow$ & 1 & 2 & 3 & 4 & 5 & Sum & \\
club $\downarrow$ & & & & & & & \\
& & & & & & & \\
Tivoli Theater 1890-1895 & & & & & & & \\
SUM members & 15 & 99 & 244 & 181 & 550 & 1089 of $1408(77.3 \%)$ \\
SUM in class & 24 & 69 & 117 & 66 & 142 & 418 of $582(71.8 \%)$ \\
mean number members & 0.6 & 1.4 & 2.1 & 2.7 & 3.9 & 2.6 & \\
\% members/sum members & 1.4 & 9.1 & 22.4 & 16.6 & 50.5 & & \\
\% cohort/sum wealth & 5.7 & 16.5 & 28.0 & 15.8 & 34.0 & & \\
& & & & & & & \\
CULTURAL & 5 & 48 & 114 & 92 & 261 & 520 & $(47.8$ valid \%) \\
Art Circle & 1 & 8 & 18 & 27 & 80 & 134 & \\
Aesthetic Society & 2 & 15 & 31 & 21 & 52 & 121 & \\
Harmony, member & 1 & 14 & 34 & 22 & 86 & 157 & \\
CULTURAL/POLITICAL & - & 7 & 6 & 6 & 23 & 42 & $(3.9$ valid \%) \\
SOCIABILITY & - & 5 & 24 & 13 & 50 & 92 & $(8.4$ valid \%) \\
Grand Club Amicitia & - & 4 & 11 & 9 & 41 & 65 & \\
Concordia Felix & - & 1 & 8 & 2 & 3 & 14 & \\
LITERARY & 1 & 2 & 5 & 6 & - & 14 & $(1.3$ valid \%) \\
Amicable Literary Exercise & 1 & 1 & 3 & 3 & - & 8 & \\
SOCIAL & 1 & 20 & 63 & 41 & 124 & 249 & $(22.9$ valid \%) \\
Soc. Public Advancement & - & 10 & 32 & 22 & 73 & 139 & \\
Elevation Publ.Entertainm. & - & 6 & 20 & 7 & 29 & 62 & \\
Floralia & 1 & 3 & 7 & 8 & 19 & 38 & \\
MUSIC & 8 & 14 & 20 & 16 & 66 & 124 & $(11.4$ valid \%) \\
Rott.Men's Choral Soc. & 7 & 12 & 13 & 11 & 20 & 63 & \\
Soc.Adv. of Music & 1 & 1 & 3 & 3 & 36 & 44 & \\
SPORT & - & - & - & - & 1 & 1 & $(0.1$ valid \%) \\
SCIENTIFIC & - & 3 & 12 & 7 & 25 & 47 & $(4.3$ valid \%) \\
Rott.Scientific Soc. & - & 3 & 12 & 5 & 24 & 44 & \\
& & & & & & & \\
& & & &
\end{tabular}

wealth class $\rightarrow$

Club $\downarrow$

Van Eijsden, 1902-1912

$\begin{array}{lllllll}\text { SUM members } & 12 & 78 & 264 & 325 & 1307 & 1986 \text { of } 2086(95.2 \%)\end{array}$

$\begin{array}{llllllll}\text { SUM in class } & 85 & 214 & 351 & 198 & 399 & 1247 \text { of } 1476(84.5 \%)\end{array}$

$\begin{array}{lllllll}\text { mean numbermembers } & 0.1 & 0.4 & 0.8 & 1.6 & 3.3 & 1.6\end{array}$

$\begin{array}{llllll}\% \text { members/sum members } & 0.6 & 3.9 & 13.3 & 16.4 & 65.8\end{array}$

$\begin{array}{llllll}\% \text { cohort/sum wealth } \quad 6.8 & 17.2 & 28.1 & 15.9 & 32.0\end{array}$

\section{CULTURAL \\ $(46.5$ valid $\%)$}

Art Circle

Aesthetic Society

Harmony, member

CULTURAL/POLITICAL

SOCIABILITY

Grand Club Amicitia

Concordia Felix

LITERARY

SOCIAL

Soc. Public Advancement

Elevation Publ.Entertainm.

Floralia

MUSIC

Rott.Men's Choral Soc.

Soc.Adv. of Music

SCIENTIFIC

Rott.Scientific Soc.

101

$\begin{array}{llll}101 & 165 & 635 & 924 \\ 40 & 70 & 222 & 340 \\ 22 & 28 & 96 & 152 \\ 32 & 51 & 205 & 298 \\ - & 9 & 42 & 52 \\ 13 & 21 & 124 & 160 \\ 10 & 11 & 103 & 125 \\ 2 & 4 & 6 & 13 \\ 7 & 5 & 10 & 23 \\ 40 & 59 & 266 & 370 \\ 28 & 43 & 160 & 234 \\ 3 & 9 & 57 & 70 \\ 7 & 6 & 38 & 52 \\ 94 & 54 & 166 & 367 \\ 60 & 27 & 54 & 179 \\ 19 & 22 & 87 & 136 \\ 6 & 11 & 57 & 74 \\ 6 & 10 & 52 & 68\end{array}$

(2.6 valid \%)

(8.1 valid \%)

(1.2 valid $\%)$

(18.6 valid \%)

(18.5 valid \%)

(3.7 valid \%) 
